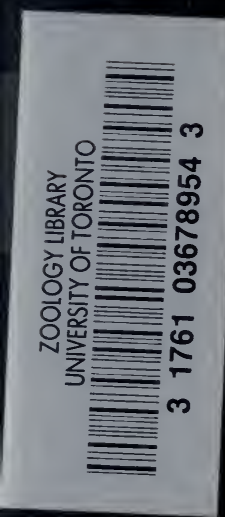





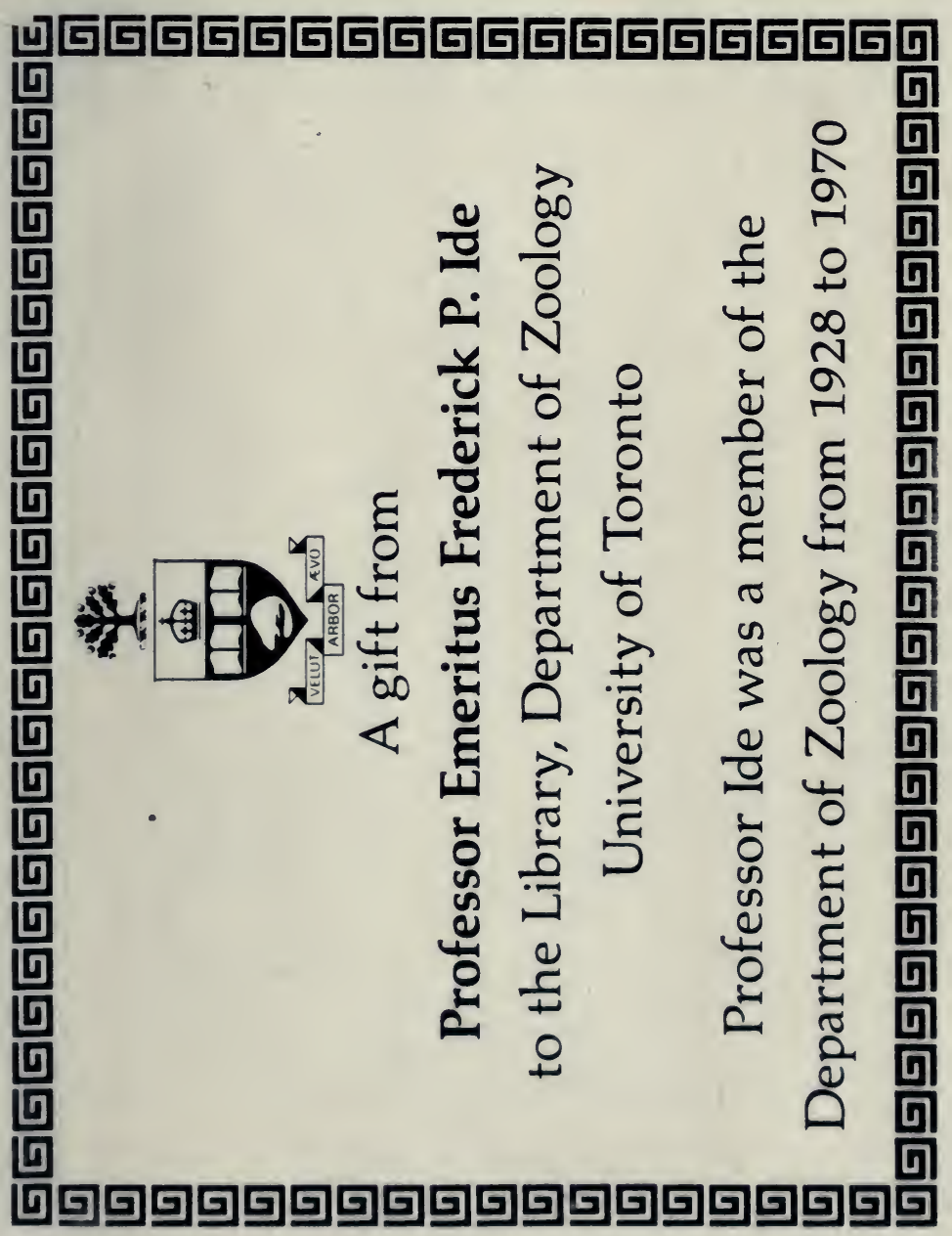


Digitized by the Internet Archive in 2008 with funding from Microsoft Corporation 


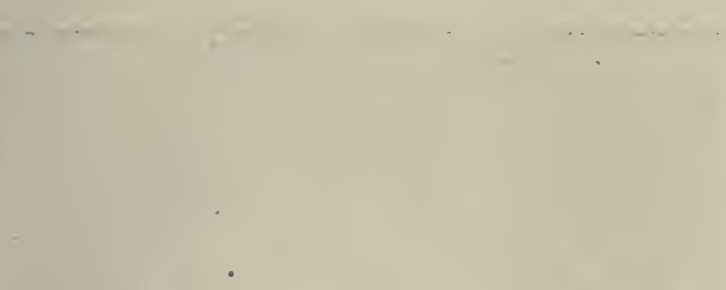




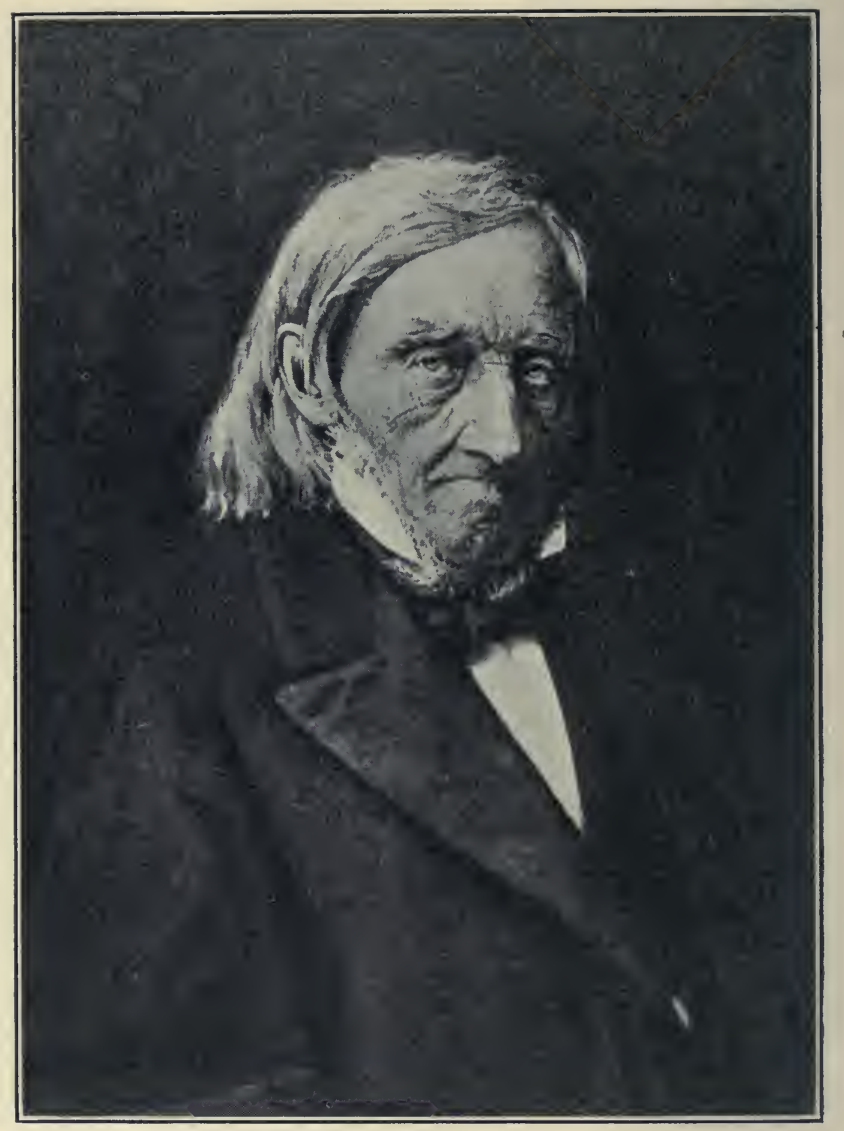

KarL ERNST VON BAER

(in old age), from the picture by Hagen-Schwarz.

(By permission of the Berlin Photographic Company, 133 New Bond Street, London, $W$.) 


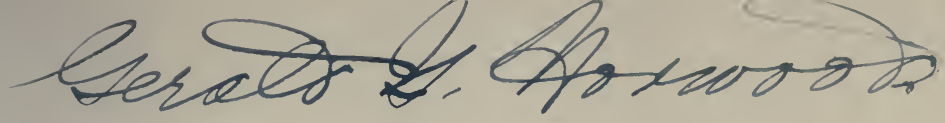

\section{HISTORY OF}

\section{B I O LOGY}

BY

L. C. MIALL, D.Sc., F.R.S.,

FORMRRLY PRORESSOR OF BIOLOGY IN THE UNIVERSITY OR LERDS

[ISSUED FOR THE RATIONALIST PRESS ASSOCIATION, LIMITED]

LONDON :

WATTS \& CO.,

I7 JOHNSON'S COURT, FLEET STREET, E.C. 

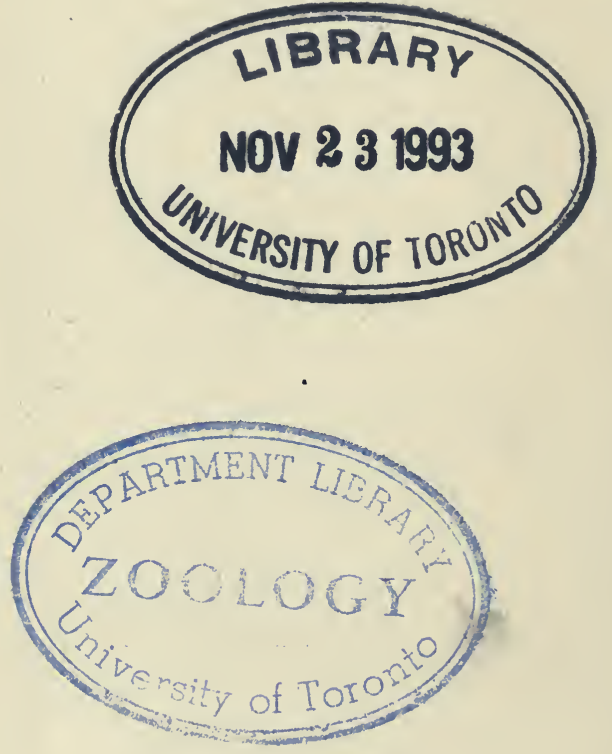


\section{CONTENTS}

INTRODUCTION

Biology of the ancients. Extinction of scientific inquiry. Revival of knowledge.

PERIOD I (1530-1660)

Characteristics of the period. The revival of botany. The revival of zoology. Early notions of system. The first English naturalists. The rise of experimental physiology. The natural history of distant lands (sixteenth century and earlier). Agriculture, horticulture, and silk-culture in the sixteenth century.

PERIOD II (166I-1740) - - - - - -

Characteristics of the period. The minute anatomists. Early notions about the nature of fossils. Comparative anatomy ; the study of biological types. Adaptations of plants and animals; natural theology. Spontaneous generation. The natural history of John Ray. The scale of nature. The sexes of flowering plants.

PERIOD III (1741-1789) - - - - - -

Characteristics of the period. Systems of flowering plants; Linnæus and the Jussieus. Réaumur and the History of Insects. The budding-out of new animals (Hydra); another form of propagation without mating (aphids). The histerical or comparative method; Montesquieu and Buffon. Amateur students of living animals. Intelligence and instinct in the lower animals. The food of green plants. The metamorphoses of plants. Early notions about the lower plants. 


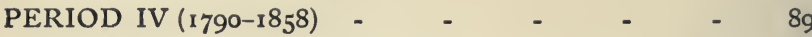

Characteristics of the period. Sprengel and the fertilisation of flowers. Cuvier and the rise of palæontology. Chamisso on the alternation of generations in Salpa. Baer and the development of animals. The cell-theory. The scientific investigation of the higher cryptogams. The enrichment of English gardens. Humboldt as a traveller and a biologist. Premonitions of a biological theory of evolution.

PERIOD V (I859 AND LATER) - - - - $\quad$ - 124

Darwin on the Origin of Species. Pasteur's experimental study of microbes.

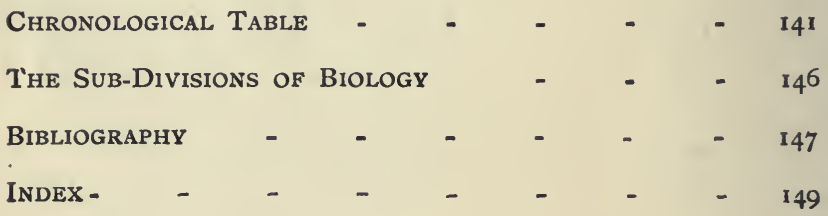




\section{LIST OF ILLUSTRATIONS}

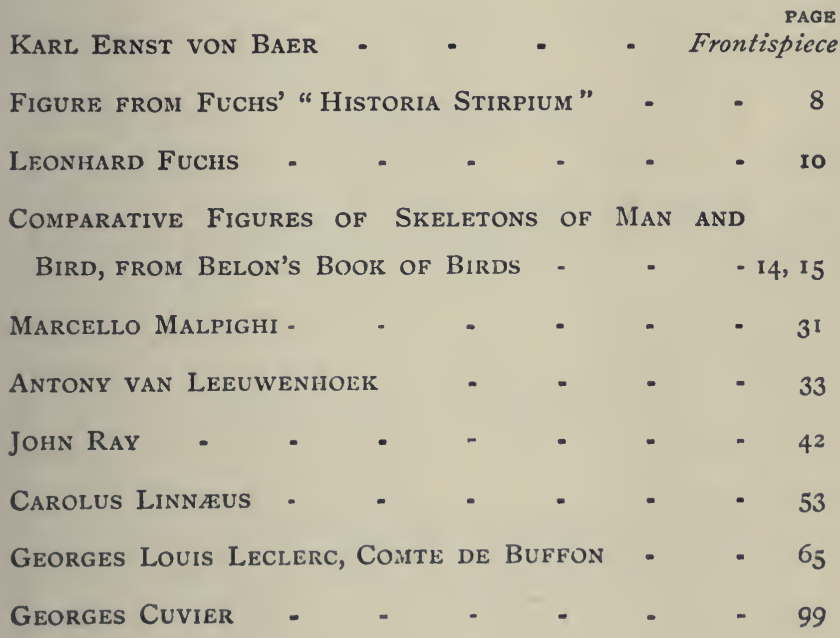





\section{INTRODUCTION}

FouR HUNDRED years ago, say in the year 1500 , Biology, the science of life, was represented chiefly by a slight and inaccurate natural history of plants and animals. Botany attracted more students than any other branch, because it was recognised as a necessary aid to medical practice. The zoology of the time, extracted from ancient books, was most valued as a source from which preachers and moralists might draw impressive emblems. Anatomy and physiology were taught out of Galen to the more learned of physicians and surgeons. Some meagre notices of the plants and animals of foreign countries, mingled with many childish fables, eked out the scanty treatises of European natural history. It was not yet generally admitted that fossil bones, teeth, and shells were the remains of extinct animals.

It is the purpose of the following chapters to show how this insignificant body of information expanded into the biology of the twentieth century; how it became enriched by a multitude of new facts, strengthened by new methods and animated by new ideas.

\section{The Blology of the Ancients.}

Long before the year 1500 there had been a shortlived science of biology, and it is necessary to explain how it arose and how it became quenched. Ancient books and the languages in which they are written teach us that in very remote times men attended to the 
uses of plants and the habits of animals, gave names to familiar species, and recognised that while human life has much in common with the life of animals, it has something in common with the life of plants. Abundant traces of an interest in living things are to be found in the oldest records of India, Palestine, and Egypt. Still more interesting, at least to the inhabitants of Western Europe, is the biology of the ancient Greeks. The Greeks were an open-air people, dwelling in a singularly varied country nowhere far removed from the mountains or the sea. Intellectually they were distinguished by curiosity, imagination, and a strong taste for reasoning. Hence it is not to be wondered at that natural knowledge should have been widely diffused among them, nor that some of them should have excelled in science. Besides all the rest, the Greeks were a literary people, who have left behind them a copious record of their thoughts and experience. Greek science, and Greek biology in particular, are therefore of peculiar interest and value.

Greek naturalists in or before the age of Alexander the Great had collected and methodised the lore of the farmer, gardener, hunter, fisherman, herb-gatherer, and physician; the extant writings of Aristotle and Theophrastus give us some notion of what had been discovered down to that time.

Aristotle shows a wide knowledge of animals. $\mathrm{He}$ dwells upon peculiar instincts, such as the migration of birds, the nest-building of the fish Phycis, the capture of prey by the fish Lophius, the protective discharge of ink by Sepia, and the economy of the hive-bee. He is fond of combining many particular facts into general statements like these: No animal which has wings is without legs; animals with paired horns have cloven 
feet and a complex, ruminating stomach, and lack the upper incisor teeth; hollow horns, supported by bony horn-cores, are not shed, but solid horns are shed every year; birds which are armed with spurs are never armed with lacerating claws ; insects which bear a sting in the head are always two-winged, but insects which bear their sting behind are four-winged. He traces analogies between things which are superficially unlike, such as plants and animals - the mouth of the animal and the root of the plant. The systematic naturalist is prone to attend chiefly to the differences between species ; Aristotle is equally interested in their resemblances. The systematic naturalist arranges his descriptions under species, Aristotle under organs or functions; he is the first of the comparative anatomists. His conception of biology (the word but not the thing is modern) embraces both animals and plants, anatomy, physiology, and system. That he possessed a zoological system whose primary divisions were nearly as good as those of Linnæus is clear from the names and distinctions which he employs; but no formal system is set forth in his extant writings. His treatise on plants has unfortunately been lost.

Aristotle, like all the Greeks, was unpractised in experiment. It had not yet been discovered that an experiment may quickly and certainly decide questions which might be argued at great length without result, nor that an experiment devised to answer one question may suggest others possibly more important than the first. Deliberate scientific experiments are so rare among the Greeks that we can hardly point to more than two-those on refraction of light, commonly attributed to Ptolemy, and those by which Pythagoras is supposed to have ascertained the numerical relations 
of the musical scale. Aristotle was the last great man of science who lived and taught in Greece. His writings disappeared from view for many centuries, and when they were recovered they were not so much examined and corrected as idolised.

Greece lost her liberty at Chaeronea, and with liberty her fairest hopes of continued intellectual development. Nevertheless, during a great part of a thousand years the Greek and Semitic school of Alexandria cultivated the sciences with diligence and success. We must say nothing here about the geometry, astronony, optics, or geography there taught, but merely note that Herophilus and Erasistratus, unimpeded by that repugnance to mutilation of the human body which had been insurmountable at Athens, made notable advances in anatomy and physiology. From this time a fair knowledge of the bodily structure of man, decidedly superior to that which Aristotle had possessed, was at the command of every educated biologist.

The genius of Rome applied itself to purposes remote from science. The example of Alexandria had its influence, however, upon some inhabitants of the Roman Empire. Galen of Pergamum in Asia Minor prosecuted the study of human anatomy. His knowledge of the parts which can be investigated by simple dissection was extensive, but he was unpractised in experimental physiology. Hence his teaching, though full with respect to the skeleton, the chief viscera, and the parts of the brain, was faulty with respect to the flow of the blood through the heart and body. Ages after his death the immense reputation of Galen, like that of Aristotle, was used with great effect to discredit more searching inquiries. Under the Roman Empire also flourished Dioscorides, who wrote on the plants used 
in medicine, and the elder Pliny, who compiled a vast, but wholly uncritical, encyclopædia of natural history.

We see from these facts how ancient nations, inhabiting the Mediterranean basin and largely guided by Greek intelligence, had not only striven to systematise that knowledge of plants and animals which every energetic and observant race is sure to possess, but had with still more determination laboured to create a science of human anatomy which should be serviceable to the art of medicine. The effort was renewed time after time during five or six centuries, but was at last crushed under the conquests of a long succession of foreign powers-Macedonians, Romans, Mohammedan Arabs, and northern barbarians-each more hostile to knowledge than its predecessors.

\section{Extinction of Seientific Inquiry.}

The decline and fall of the Roman Empire brought with it the temporary extinction of civilisation in a great part of Western Europe. Science was during some centuries taught, if taught at all, out of little manuals compiled from ancient authors. Geometry and astronomy were supplanted by astrology and magic ; medicine was rarely practised except by Jews and the inmates of religious houses. Literature and the fine arts died out almost everywhere.

No doubt the practical knowledge of the farmer and gardener, as well as the lore of the country-side, was handed down from father to son during all the ages of darkness, but the natural knowledge transmitted by books suffered almost complete decay. The teaching ascribed to Physiologus is a sufficient proof of this statement. Physiologus is the name given in many languages during a thousand years to the reputed 
author of popular treatises of zoology, which are also called Bestiaries, or books of beasts. Here it was told how the lion sleeps with open eyes, how the crocodile weeps when it has eaten a man, how the elephant has but one joint in its leg and cannot lie down, how the pelican brings her young back to life by sprinkling them with her own blood. The emblems of the Bestiaries supplied ornaments to mediæval sermons; as late as Shakespeare's day poetry drew from them no small part of her imagery; they were carved on the benches, stalls, porches, and gargoyles of the churches.

In the last years of the tenth century A.D. faint signs of revival appeared, which became distinct in another hundred years. From that day to our own the progress has been continuous.

\section{Revival of Knowledge.}

By the thirteenth century the rate of progress had become rapid. To this age are ascribed the introduction of the mariner's compass, gunpowder, reading glasses, the Arabic numerals, and decimal arithmetic. In the fourteenth century trade with the East revived; Central Asia and even the Far East were visited doy Europeans; universities were multiplied; the revival of learning, painting, and sculpture was accomplished in Italy. Engraving on wood or copper and printing from moveable types date from the fifteenth century. The last decade of this century is often regarded as the close of the Middle Ages; it really marks, not the beginning, but only an extraordinary acceleration, of the new progressive movement, which set in long before. To the years between 1490 and 1550 belong the great geographical discoveries of the Spaniards in the West and of the Portuguese in the East, as well as the Reformation and the revival of science. 


\section{PERIOD I.}

\section{I530-1660}

\section{Characteristics of the Period.}

THIs is the time of the revival of science; the revival of learning had set in about two centuries earlier. Europe was now repeatedly devastated by religious wars (the revolt of the Netherlands, the wars of the League in France, the Thirty Years' war, the civil war in England). Learning was still mainly classical and scholastic; nearly every writer whom we shall have occasion to name had been educated at a university, and was able to read and write Latin. Two great extensions of knowledge helped to widen the thoughts of men. It became known for the first time that our planet is an insignificant member of a great solar system, and that Christendom is both in extent and population but a small fraction of the habitable globe.

\section{The Revival of Botany.}

Botany was among the first of the sciences to revive. Its comparatively early start was due to close association with the lucrative profession of medicine. Medicine itself was slow to shake off the unscientific tradition of the Middle Ages, and its backwardness favoured, as it happened, the progress of botany. In the sixteenth century the physician was above all things the prescriber of drugs, and since nine-tenths of the drugs were got from plants, botanical knowledge was reckoned as one of his chief qualifications. All physicians 


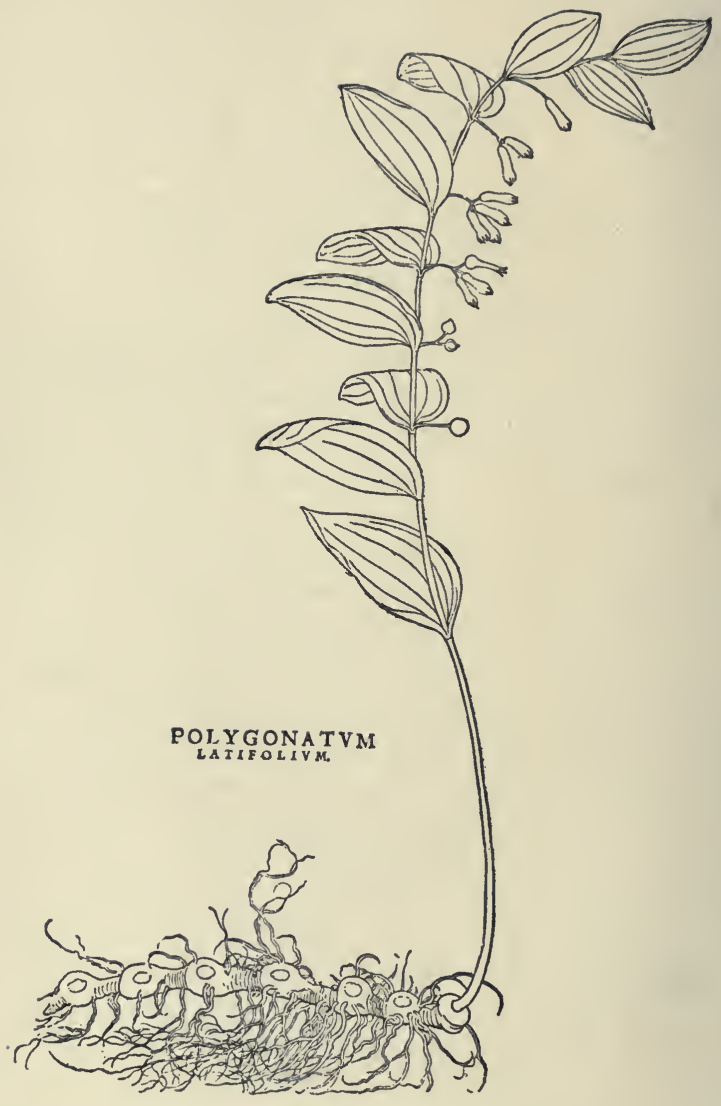

Figure of Solomon's Seal.

From Fuchs' Historia Stirpium, r542. The original occupies a folio page. 
professed to be botanists, and every botanist was thought fit to practise medicine.

Three Germans, who were at once botanists and physicians-Brunfels, Bock, and Fuchs-led the way by publishing herbals, in which the plants of Germany were described and figured from nature. Their first editions appeared in the years I530, I 539, and $\mathrm{I}_{542}$. Illustrated herbals were then no novelty, but whereas they had hitherto supplied figures which had been copied time after time until they had often ceased to be recognisable, Brunfels set a pattern of better things by producing what he called "herbarum vivæ eicones," life-like figures of the plants. Each of the three new herbals contained hundreds of large woodcuts. Those engraved for Fuchs are probably of higher artistic quality than any that have appeared since. Each plant, drawn in clear outline without shading, fills a folio page, upon which the text is not allowed to encroach. The botanist will, however, remark that enlarged figures are hardly ever given, so that minute flowers show as mere dots, and that the details of the foliage are not so scrupulously delineated as in modern figures. The text of Brunfels and Fuchs is of little interest, being largely occupied with traditional pharmacy. Bock, whose figures are inferior to those of Brunfels and Fuchs, makes up for this deficiency by his graphic and sometimes amusing descriptions. He delights in natural contrivances, such as the hooks on the twining stem of the hop, or the elastic membrane which throws out the seeds of wood-sorrel. Brunfels has no intelligible sequence of species; Fuchs abandons the attempt to discover a natural succession, and adopts the alphabetical order; Bock aims at bringing together plants which show mutual affinity ("Gewåchs einander ver- 


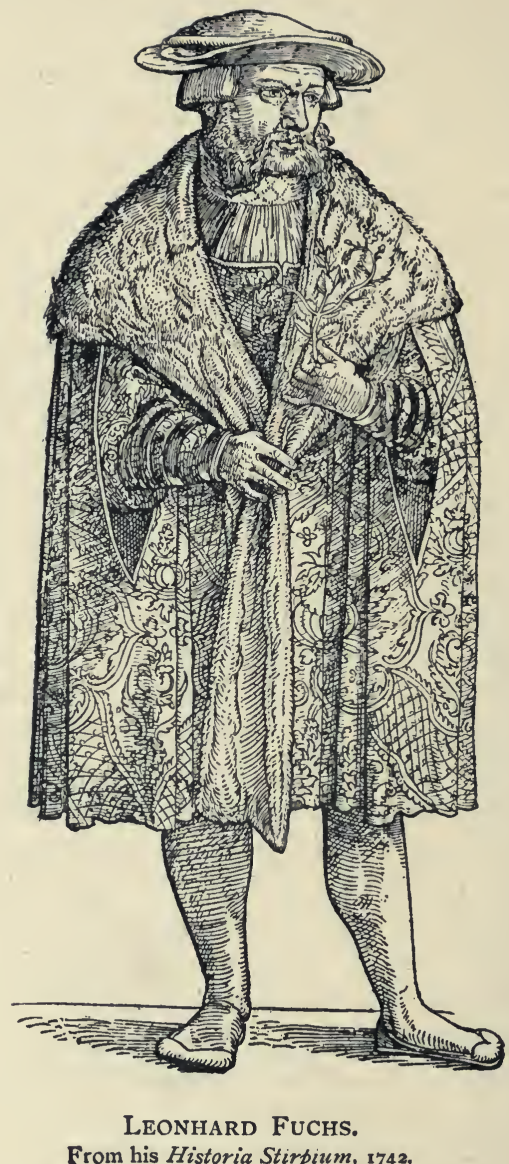


wandt"), though such natural groups as he recognises are neither named nor defined.

These three German herbals really deserve to be called scientific. To figure the plants of Germany from the life, to exclude such as existed only in books, and to strive after a natural grouping, was a first step towards a fruitful knowledge of plant-life. It is worth while to dwell for a moment upon the place where these herbals were produced. Along the Rhine civilisation and industry had for many years flourished together. Here and in the country to the east of the great river had sprung up that powerful union of seventy cities known in the thirteenth century as the Confederation of the Rhine ; four universities, three of them on the banks of the Rhine, had been founded; here printing and wood-engraving had established themselves in their infancy; here, too, the Reformation found many early supporters. There were historical, economic, and moral reasons why the first printed books on natural history, illustrated by wood-cuts drawn from the life, should have been produced in the Rhineland, and why all their authors should have been Protestants. Nearly every sixteenth-century botanist held the same faith.

The success of the first German herbalists brought a crowd of botanists into the field, among whom were several whose names are still remembered with honour. Gesner of Zurich made elaborate studies for a great history of plants, which he did not live to complete. It was he who first pointed out that the flower and fruit give the best indications of the natural relationships of plants, and his many beautiful enlarged drawings set an example which has done much for scientific botany. Botanists began to understand what natural grouping means, and to recognise that truly 
natural groups are not to be invented, but discovered. The almost accidental succession adopted by Brunfels, the alphabetical succession of Fuchs, the division according to uses (kitchen-herbs, coronary or garlandflowers, etc.), and the logical, but too formal, method of Cesalpini, in which, as in modern classification, much use was made of the divisions in the ovaryall these were left behind. L'Obel separated, unconsciously and imperfectly, the Monocotyledons from the Dicotyledons, recognised several easily distinguished families of flowering plants (grasses, umbellifers, labiates, etc.), and framed the first synoptic tables of genera.

\section{The Revival of Zoology.}

While the physicians of the Rhineland were describing and figuring their native plants, the study of animals began to revive. Two very different methods of work were tried by the zoologists of the sixteenth century. One set of men, who may be called the Encyclopædic Naturalists, were convinced that books, and especially the books of the ancients, constituted the chief source of information concerning animals and most other things. They extracted whatever they could from Aristotle, Alian, and Pliny, adding all that was to be learned from the narratives of recent travellers, or from the collectors of skins and shells. The books on which they chiefly depended, being for the most part written by men who had not grappled with practical natural history and its problems, were unfortunately altogether inadequate. Many of the statements brought together by the encyclopædic naturalists were illattested; some were even, ridiculously improbable. If inferences from the facts were attempted-and this was rare-they were more often propositions of morality or. 
natural theology than the pregnant thoughts which suggest new inquiries. Hence the encyclopædic plan, even when pursued by men of knowledge and capacity, such as Gesner and Aldrovandi, yielded no results proportional to the labour bestowed upon it ; the true path of biological progress had been missed. Naturalists of another school described and figured the animals of their own country, or at least animals which they had closely studied. Rondelet described from personal observation the fishes of the Mediterranean; Belon described the fishes and birds that he had met with in France and the Levant. His Book of Birds ( 1555$)$ is a folio volume in which some two hundred species are described and figured. The "naturel" (natural history of the species) contains many curious observations. Perhaps the best things in the book are two figures placed opposite one another and lettered in correspondence; one shows the skeleton of a bird, the other that of a man. The example of Rondelet and Belon was followed by other zoological monographers, who did more for zoology than all the learning of the encyclopædists.

\section{Early Notions of System.}

Simple-minded people, who do not feel the need of precision in matters of natural history, have in all ages divided animals into four-footed beasts which walk on the earth, birds which fly, fishes which swim, and perhaps reptiles which creep. This is the classification found in the Babylonian and Hebrew narratives of the great flood. Plants they naturally divide into trees and herbs. It was not very long, however, before close observers became discontented with so simple a grouping. They discovered that the bat is no bird, though it flies; that the whale is no fish, though it 


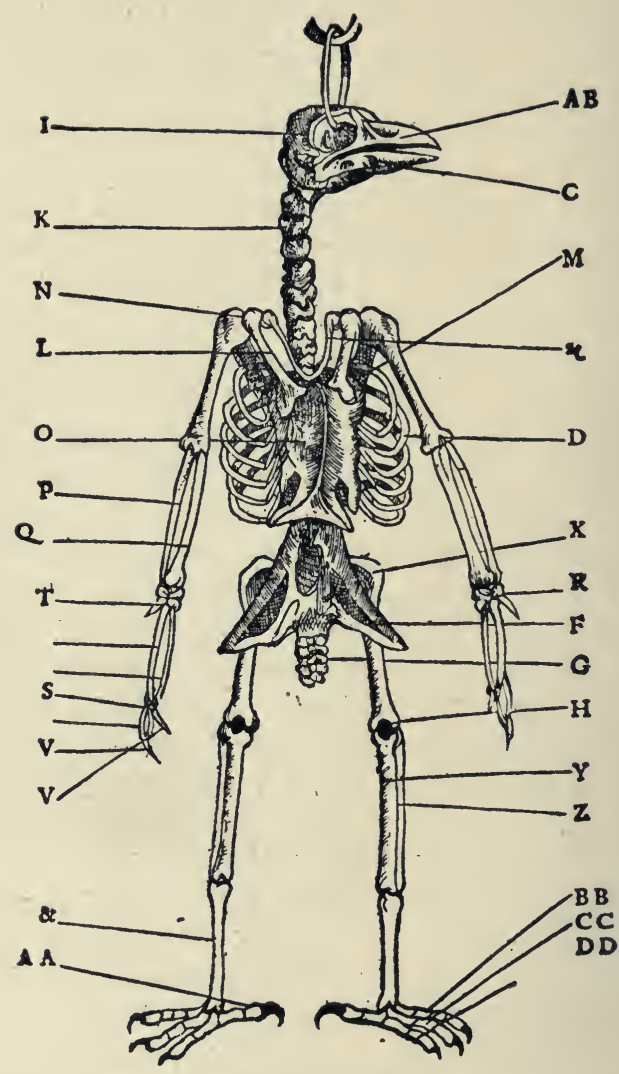

BiRd's SKELETON.

For cumparison with human skeleton (opposite), lettered to show the answerable bones. From Belon's Book of Birds, $1_{555}$ 


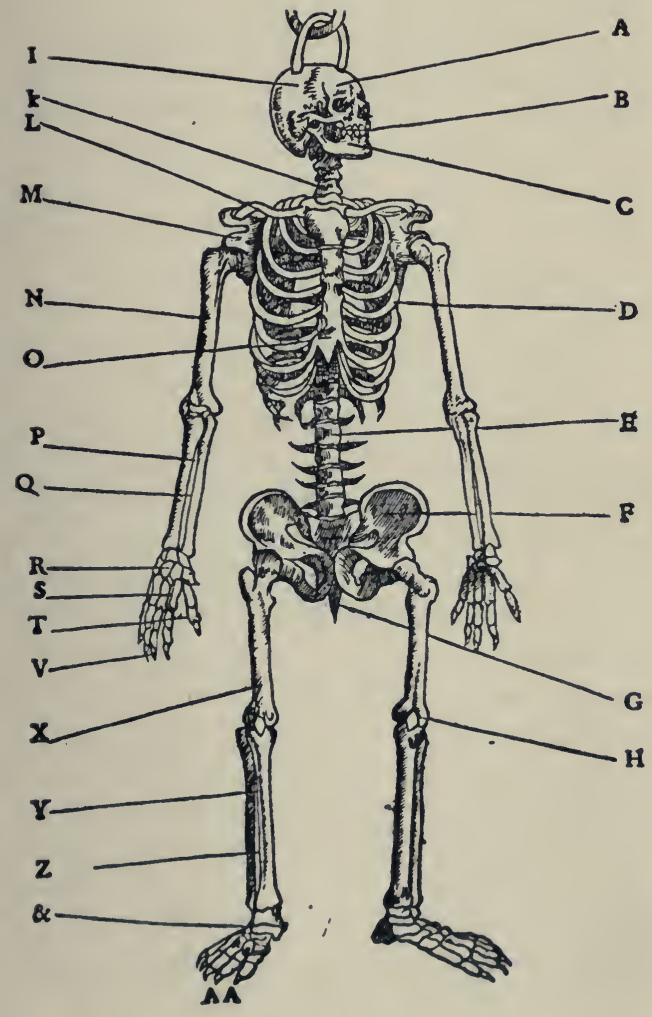

Human Skeleton.

For comparison with bird's skeleton (opposite), lettered to show the answerable bones. From Belon's Book of Birds, 1555. 
swims; that the snake comes nearer in all essentials to the four-footed lizard, and even to the beast of the field, than to the creeping earthworm. At a much later time they discovered that pod-bearing or rose-like herbs may resemble pod-bearing or rose-like trees more closely than all trees resemble each other. Moreover, a multitude of animals became known which cannot be classed as either beasts, birds, fishes, or reptiles, and a multitude of plants which cannot be classed as either trees or herbs.

Aristotle found himself obliged to rectify the traditional classification of animals in order to remove gross anomalies. When learning decayed the traditional classification came back. Thus the Ortus Sanitatis (first published in 1475 , and often reprinted) adopts the division into (I) animals and things which creep on the earth; (2) birds and things which fly; (3) fishes and things which swim. No consistent primary division of plants was proposed by Greek or Roman, nor by anyone else until the seventeenth century A.D.

This conflict of systems should have raised questions concerning the nature of classification and the relative value of characters. Some of the most striking resemblances found among animals and plants are only superficial ; others, though far less obvious, are fundamental. Whence this difference? Why should scientific zoology make so little of the place of abode and the mode of locomotion; so much of the mode of reproduction and the nature of the skeleton? The answers were vague, and even the questions were rare and indistinct. But a metaphorical term came into use which was henceforth more and more definitely associated with fundamental, as distinguished from 
adaptive, likeness. Such likeness was called affinity, ${ }^{\mathbf{x}}$ though no attempt was made to explain in what sense the term was to be understood. As late as the year I 835 one of the first botanists in Europe (Elias Fries) could say no more about affinity between species than that it was quoddam supernaturale, a supernatural property.

A tolerable outline of a classification of animals was attained much earlier than a tolerable classification of plants. The characters available for the classification of plants are, to begin with, less obvious than those which the zoologist can employ. Moreover, the botanists were restricted to a narrower view of their subject. Zoologists, though they were expected to bestow the best part of their time upon vertebrates, were encouraged to study all animals more or less. Botanists, on the other hand, were practically obliged to concentrate their attention upon the classification of the flowering plants. The physician, herb-collector, and gardener cared nothing about any plants except such as bear flowers and fruit; but of these they expected full descriptions, and were clamorous for a system which would enable even a tyro to make out every species with certainty and ease. The task set before the botanist was comparable in respect of difficulty with the construction of a detailed and completely satisfactory classification of birds, which zoology has never yet been able to produce, while for the sake of this long-unattainable object almost everything else in botany was neglected.

The First English Naturalists.

During the greater part of three centuries ( 1300 to

- Aristotle, Cesalpini, Gesner, and Ray are among the writers who use this word or some synonym. 
1600 ), while the revival of learning and science was proceeding actively in Italy, France, Switzerland, and the Rhineland, England lagged behind. Humanist studies were indeed pursued with eminent success in the England of Sir Thomas More, but there was little else for national pride to dwell upon. The re-opening of ancient literature, the outpouring of printed books, the Reformation, the new mathematics and astronomy, the new botany and zoology, were mainly the work of foreigners. Before the seventeenth century no Englishman was recognised as the founder of a scientific school.

Passing over Edward Wotton (I492-1555), who recast the zoology of Aristotle with very little effect upon the progress of biology, we may head the list of English naturalists with the name of William Turner (d. I 568), who wrote on the plants and birds of Britain. Turner was a Reformed preacher, who had been the college friend of Ridley and Latimer. Being banished for preaching without licence, he studied medicine and botany in Italy, at Basle and at Cologne. Under Edward VI. he returned to England and was made Dean of Wells, fled again to the Continent on Mary's accession, was re-instated by Elizabeth, was suspended for nonconformity, and died not long after. Turner's herbal $\left({ }_{55} \mathrm{I}-63\right)$ cannot be said to have done much for English botany. The arrangement is alphabetical, the properties and virtues of the plants are described out of ancient authors, and most of the figures are borrowed. Still, it was something to have the common plants of England examined by a man who had studied under Luke Ghini, had botanised along the Rhine, and was the pupil, friend, and correspondent of Conrad Gesner, the most learned naturalist in Europe. Turner's History 
of Birds (Historia Avium) was published in Latin at Cologne in $1544,{ }^{\mathrm{x}}$ and is therefore earlier than Belon's book of birds. The history contains here and there among passages culled from the ancients a sprightly description of the feeding or nest-building of some English bird, and furnishes evidence of the breeding in our islands of birds which, like the crane, have long been known to us only as rare visitants. Of the kite Turner says that in the cities of England it used to snatch the meat out of the hands of children. In his day the osprey was better known to Englishmen than they liked, for it emptied their fishponds; anglers used to mix their bait with its fat. Turner shows not a little of that spirit of close observation which in a later and more tranquil age shone forth in Gilbert White.

Dr. John Caius (the name is supposed to be a Latinised form of Kay), the second founder of a great Cambridge college, was physician in succession to Edward VI., Mary, and Elizabeth ; in his youth he had studied under Vesalius at Padua. Like Turner he was a friend and correspondent of Gesner, for whom he wrote an account of the dogs of Britain (De Canibus Britannicis, printed in Latin in 1570 ), which attempts to classify all the breeds, and to give some account of the uses to which each was put. The list contains no bull-dog, pointer, or modern retriever. There is a water-spaniel, however, and dogs had already been trained to retrieve game. The turnspit, which was not a distinct breed (Caius calls it a mongrel), has long been superseded. Curious antiquarian information, such as mention of the weapons formerly used by sportsmen,

I It has now been made accessible to all readers by the reprint and translation of Mr. A. H. Evans. 
and obsolete names of dogs, reward the reader of this short tract.

Thomas Moufet wrote (for Gesner again) a book on insects, which incorporated the notes of Penny and Wotton. None of the three lived to see the printed book, which was at last put forth by Sir Thomas Mayerne in I634. It is uncritical, confused, and illustrated by the rudest possible woodcuts.

John Gerarde's Herbal (1597) and Parkinson's two books of plants are more amusing than valuable. Both authors were guilty of unscrupulous plagiarism, a vice which cannot be atoned for by curious figures and bits of folk-lore, nor even by command of Shakespearean English. Thomas Johnson's edition of Gerarde ( $16_{33}$ ) is a far better book than the original; Ray called it "Gerarde emaculatus"-i.e., freed from its stains.

The succession of influential English naturalists may be said to begin with Ray, Willughby, and Martin Lister, all of whom belong to the last half of the seventeenth century.

\section{The Rise of Experimental Physiology.}

I 543 is a memorable year in the history of science. Then appeared the treatise of Copernicus on the Revolutions of the Heavenly Bodies, completed long before, but kept back for fear of the cry of novelty and absurdity which, as he explains in his preface, dull men, ignorant of mathematics, were sure to raise. The aged astronomer, paralysed and dying, was able to hold his book in his hands before he passed away. In the same year Vesalius, a young Belgian anatomist, published his Structure of the Human Body, a volume rich in facts ascertained by dissection. Some of these facts were held to contradict the teaching of Galen. 
Next year Vesalius was driven by the hostility of the medical profession to burn his manuscripts and relinquish original work; he was not yet thirty years of age.

Galen had taught that there are two sets of vessels in the body (arteries and veins), and that in each set there is an ebb and flow. Knowing nothing of communications between the ultimate branches of the arteries and veins, and shrinking from the supposition that the arteries and veins are entirely separate and distinct, Galen had taught that the blood passes from one set of vessels to the other in the heart. The septum between the ventricles must be porous and allow the blood to soak through. Vesalius did not venture openly to challenge the physiology of Galen, but he significantly admired the "handiwork of the Almighty," which enables the blood to pass from the right to the left ventricle through a dense septum in which the eye can perceive no openings. Fabricius of Acquapendente in I 574 demonstrated the valves of the veins, though he never arrived at a true notion of their action. His celebrated pupil, William Harvey, who had been anticipated on important points by the Spaniard Michael Servetus and Realdo Columbo of Cremona, published in 1628 a clear account, supported by adequate experimental evidence, of the double circulation through the body and the lungs, and of the communications between the arteries and the veins in the tissues-communications which it was reserved for the next generation to demonstrate by the microscope.

Aselli of Cremona rediscovered the lacteals in 1622 ; they had been known ages before to Erasistratus, but forgotten. Opening the abdomen of a dog, he saw a multitude of fine white threads scattered over the mesentery, and observed that when one of them was 
pricked a liquid resembling milk gushed out. Further examination showed him that these vessels, like the veins, possess valves which permit flow in one direction only. Pecquet, a French physician, announced in $16_{5} \mathrm{I}$ that the lacteals open into a thoracic duct, which joins the venous system. In 1653 Rudbeck of Upsala described yet another set of vessels, the lymphatics; these again are provided with valves, and open into the thoracic duct, but are filled with a clear liquid.

The effect of these discoveries upon physiology and medicine was very great, but it did not end there; the whole circle of biological students and a still wider circle of men who pursued other sciences were thereby encouraged to follow the experimental path to knowledge. Wallis, in describing the meetings of scientific men held in London in 1645 and following years, mentions the circulation of the blood, the valves in the veins, the lacteals, and the lymphatic vessels among the subjects which had stirred their curiosity; while the naturalist Ray thanked God for permitting him to see the vain philosophy which had pervaded the University in his youth replaced by a new philosophy based upon experiment-a philosophy which had established the weight and spring of the air, invented the telescope and the microscope, and demonstrated the circulation of the blood, the lacteals, and the thoracic duct.

\section{The Natural History of Distant Lands (Sixteenth Century and Earlier).}

Travel and commerce had made the ancient world familiar with many products of distant countries. Wellestablished trade routes kept Europe in communication with Arabia, the Persian Gulf, and India. Egyptians, 
Phœnicians, and Greeks explored every known sea, and brought to Mediterranean ports a variety of foreign wares. Under the Roman empire strange animals were imported to amuse the populace; silk, pearls, gay plumage, dyes, and drugs to gratify the luxury of the rich.

Long after the fall of the empire foreign trade was kept up along the coasts of the Mediterranean. Constantinople was still a great emporium. Silk was not only imported from the East, but cultivated around Constantinople in the sixth century. The cotton plant, the sugarcane, the orange tree, and the lemon tree gradually spread northward and westward until they became established in Italy, Spain, and the islands of the Mediterranean.

Western Europe had during many centuries little share in this commerce. The large and conspicuous animals of Africa and Asia, such as the elephant, camel, camelopard, ostrich, pelican, parrot, and crocodile, would have passed out of knowledge altogether but for chance mention in the Bible and the Bestiaries. Little was done to supplement native food-plants and drugs by imported products, and the knowledge of foreign vegetation became as indistinct as that of foreign animals.

In the thirteenth century communication between Western Europe and the far East was restored. China was thrown open by the Tartar conquest, and Marco Polo was able to reach the court of Khan Kublai. Pilgrims from the Holy Land brought back information which, however scanty it might be, was eagerly received. One of the earliest printed books (1486) contains the travels of Bernard of Breydenbach, a canon of Mainz, whose narrative is adorned by curious 
woodcuts, in which we can make out a giraffe and a long-tailed macaque.

The geographical discoveries of the sixteenth century gave men for the first time a fairly complete notion of the planet which they inhabit. Circumnavigators proved that it is really a globe. Maps of the world, wonderfully exact considering the novelty of the information which they embodied, were engraved as early as 1507. The explorers of America busied themselves not only with the preparation of charts, the conquest of Mexico and Peru, the search for gold, and the spread of the true faith, but also with the strange animals and plants which they saw; and the news which they brought back was eagerly received in Europe. Queen Isabella charged Columbus, when he set out for his second voyage, to bring her a collection of bird-skins; but this may be rather a proof of her love of millinery than of her interest in natural history. Pope Leo X. liked to read to his sister and the cardinals the Decades of Peter Martyr Anglerius, ${ }^{x}$ in which the productions of the New World are described. The opossum, sloth, and ant-eater, the humming-bird, macaw, and toucan, the boa, monitor, and iguana, were made known for the first time. Potatoes and maize began to be cultivated in the south of Europe, the tomato was a well-known garden plant, the prickly pear was spreading along the shores of the Mediterranean, and tobacco was largely imported. By the end of the seventeenth century Mirabilis and the garden Tropæolum had been brought from Peru, the so-called African marigold from Mexico, and sunflowers from North America. More than a hundred years had still.

Letter of Peter Martyr, Dec. 26,-1515. 
to run before the evening primrose, the passion flower, and the lobelias of America were to become familiar to European gardeners, ipecacuanha and cinchona to European physicians.

\section{Agriculture, Horticulture, and Silk-Culture in the Sixteenth Century.}

During the darkest parts of the Middle Ages agriculture and horticulture were regularly practised. Tyranny, the greed of settlers, the inroads of barbarians, private war, and superstition may destroy all that brightens human life, but they hardly ever exterminate the population of large districts, ${ }^{\mathrm{I}}$ and so long as men live they must till the soil.

The age of Charlemagne was one of cruel hardship to the inhabitants of Western Europe, but the cartularies of the great king show that the improvement of horticulture was a matter of much concern with him. The nobles and the religious houses kept trim gardens, which are delineated in mediæval paintings We know less about the state of the peasantry, but it is clear that they ploughed, sowed, reaped, and dug their little gardens, however uncertain the prospect of enjoying the produce of their labour.

The progressive Middle Ages (about 1000 to 1500 A.D.) greatly increased the comfort of the wealthy and alleviated the miseries of the poor. We now hear of countries (England, the Low Countries, the western half of Germany, the northern half of Italy) where freemen cultivated their own land, or grew rich by trade, and these men were not content barely to support

The extermination of the red man in North America is the most conspicuous case recorded in history. Australia and Tas. mania furnish examples on a smaller scale. 
life. Under the later Plantagenets the wool-growers of that upland country which stretches from Lincolnshire to the Bristol Channel showed their wealth by building a profusion of manor-houses and beautiful perpendicular churches, many of which still remain. There can be little doubt that they were attentive to the rural industries which are so great a source of comfort and pleasure.

In the sixteenth and seventeenth centuries the Flemings, a laborious and enterprising people, inhabiting a fertile country, excelled the rest of Europe in agriculture and horticulture. L'Obel, himself a Fleming, speaks with pride of the live plants imported into Flanders from Southern Europe, Asia, Africa, and America. By the close of the sixteenth century, or a few years later, the lilac, lavender, marigold, sunflower, tulip, and crown-imperial, the cucumber and garden rhubarb, besides many improved varieties of native vegetables, were sent out from Flanders to all parts of Western Europe. During many generations English agriculture and horticulture, and not these alone, but English ship-building, navigation, engineering, and commerce as well, looked to the Low Countries as the chief schools of invention and the chief markets from which new products were to be obtained.

Late in the sixteenth century a gentleman of the Vivarais (the modern Ardèche), named Olivier de Serres, wrote a book on the management of land, ${ }^{\mathrm{x}}$ which leaves a strong impression of the zeal for improvement which then pervaded Europe. De Serres was above all things intent upon extending silk-culture in France.

x Le Theâtre d' Agriculture, 1600. 
On this topic he wrote with full knowledge, having reared silkworms for thirty-five years. The King, Henri Quatre, shared his hopes, and gave him practical encouragement. It is well known that a great industry was thus started; by 1780 the annual yield of silkcocoons in France was valued at near a million sterling, while in 1848 it had risen to four millions. De Serres sought to promote the cultivation of the mulberry tree, not only because its leaves are the food of the silkworm, but because he believed that the fibres of the bast would be serviceable in the manufacture of cordage and cloth. $\mathrm{He}$ also tried to revive the ancient practice of hatching eggs by artificial heat. We learn from him that the turkey, recently introduced from Mexico, had already become an important addition to the poultry-yard, while maize from Mexico and beetroot from the Mediterranean coasts were profitable crops. Among the new appliances De Serres mentions artificial meadows, wind and water-mills, cisterns not hewn from stone, and greenhouses. 


\title{
PERIOD II.
}

\author{
I66I-I740
}

\section{Characteristics of the Period.}

IN Western Europe this was a time of consolidation succeeding to one of violent change. Religious wars gave place to dynastic and political wars. In France the tumults of the preceding hundred years sank to rest under the rule of a strong monarchy; order and refinement became the paramount aims of the governing classes; literature, the fine arts, and the sciences were patronised by the Court. Other nations imitated as well as they could the example of France. Learning was still largely classical, but the anti-scholastic revolt, which had first made itself felt three hundred years earlier, steadily gained ground; Descartes, Newton, and Locke were now more influential than the Aristotelians. This was an age of new scientific societies (Royal Society, Academy of Sciences of Paris, Academia Naturæ Curiosorum, etc.).

\section{The Minute Anatomists.}

Magnifying glasses are of considerable antiquity. Seneca mentions the use of a glass globe filled with water in making small letters larger and clearer. Roger Bacon (1276) describes crystal lenses which might be used in reading by old men or those whose sight was impaired. As soon as Galileo had constructed his first telescopes, he perceived that a similar instrument might be caused to enlarge minute objects, and made 
a microscope which revealed the structure of an insect's eye. Within twenty years of this date the working opticians of Holland, Paris, and London sold compound microscopes, which, though cumbrous as well as optically defective, revealed many natural wonders to the curious. Simple lenses, sometimes of high power, came before long to be preferred by working naturalists, and it was with them that all the best work of the seventeenth and eighteenth centuries was done.

The power of the microscope as an instrument of biological research was in some measure revealed by Hooke's Micrographia (1665). Robert Hooke was a man of extraordinary ingenuity and scientific fertility, who took a leading part in the early work of the Royal Society. He opens his book with an account of the simple and the compound microscope of his own day, and then goes on to explain, with the help of large and elaborate engraved plates, the structure of a number of minute objects. The most interesting are : A Foraminiferous shell, snow-crystals, a thin section of cork showing its component cells, moulds, a bit of Flustra, the under side of a nettle-leaf with its epidermic cells and stinging-hairs, the structure of a feather, the foot of a fly, the scales of a moth's wing, the eye of a fly, a gnat-larva, and a flea. The beauty of the plates and the acuteness of some of the explanations are remarkable, but lack of connection between the topics discussed hinders the Micrographia from rising to a very high scientific level.

Swammerdam treated the microscope as an instrument of continuous biological research. In his eyes it was a sacred duty to explore with the utmost faithfulness the minute works of the Creator. Insects yielded him an inexhaustible supply of natural contrivances, in 
which closer scrutiny always brought to view still more exquisite adaptations to the conditions of life. He was able to throw a beam of steady light upon the perplexed question of insect-transformation, and swept from his path the sophistries with which the philosophy of the schools had obscured the change of the caterpillar into a moth, or of the tadpole into a frog. $\mathrm{He}$ demonstrated the gradual progress of the apparently sudden transformation of certain insects by dipping into boiling water a full-fed caterpillar, and then exposing the parts of the moth or butterfly, which had almost attained their complete form beneath the larval skin; after this it was easy to discover the same parts in the pupa.

There is no more valuable chapter in Swammerdam's great work, the Biblia Natura, or Book of Nature, than that devoted to the hive-bee. This insect had long been a favourite study, but only those who were armed with a microscope and skilled in minute anatomy could solve the many difficult questions with which it was involved. Aristotle and other ancient naturalists had spoken of the king of the bees, which some beemasters of the seventeenth century had been inclined to call the queen. Was' it really true that the queen was a female, perhaps the only female in the hive? This question Swammerdam decided by the clearest anatomical proof-viz., by dissecting out her ovaries. He pointed out the resemblances between the queen and the workers, such as the possession of a sting by both, but did not discover the reduced reproductive organs of the workers, and wrongly declared that they never lay eggs. He proved by elaborate dissections that the drones are the males of the community. How and when the queen is fertilised he could not make out. 


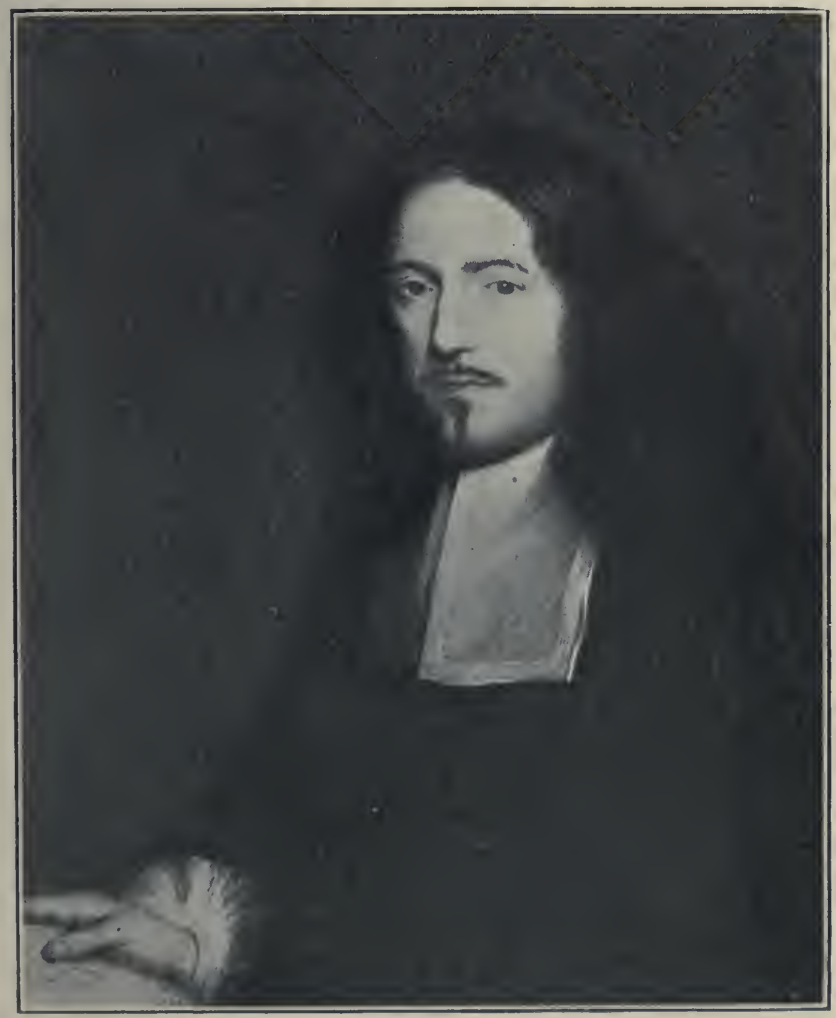

Marcello Malpighi.

From an engraving of the oil-painting by A. M. Tobar, presented to the Royal Society by Malpighi. 
The dissection of the sting, the proboscis, and the compound eye of the bee was a task after Swammerdam's own heart, but so intricate that all his patience and skill could not save him from occasional slips. $\mathrm{He}$ bequeathed to his successors many noble examples of the way in which life-histories ought to be investigated.

Malpighi of Bologna may be called the first of the histologists, for as early as the second half of the seventeenth century he unravelled the tissues of many animals and plants. His work on plant-tissues was so closely accompanied by the similar researches of an Englishman, Nehemiah Grew, that it is not easy to assign the priority to either. Malpighi was the first to demonstrate the capillaries which connect the arteries with the veins, the first to investigate the glands of the human body and the sensory papillæ of the skin. At the request of our Royal Society he drew up an account of the structure and life-history of the silkworm, which is memorable as the earliest anatomical study of any insect. Malpighi also applied his microscope to the chick-embryo, and figured its chief stages. His exposition of the formation of the heart and vessels of the chick is a marvellous example of the quick appreciation of novel structures.

If we suppose the Micrographia of Hooke to be greatly enlarged, so as to become, instead of the passing occupation of a man busied with a hundred other interests, the main pursuit of a long and laborious life, we shall get a rough notion of the microscopic revelations of Leeuwenhoek. His researches were desultory, though not quite so desultory as Hooke's ; he must have often spent months upon an investigation which Hooke would have dismissed in as many weeks. Both travelled over the whole realm of nature, and 
lacked that concentration which made the work of Swammerdam so productive and so lasting.

Leeuwenhoek worked with simple lenses, ground and mounted by his own hands. It was easy to make lenses of high magnifying power, but hard to correct

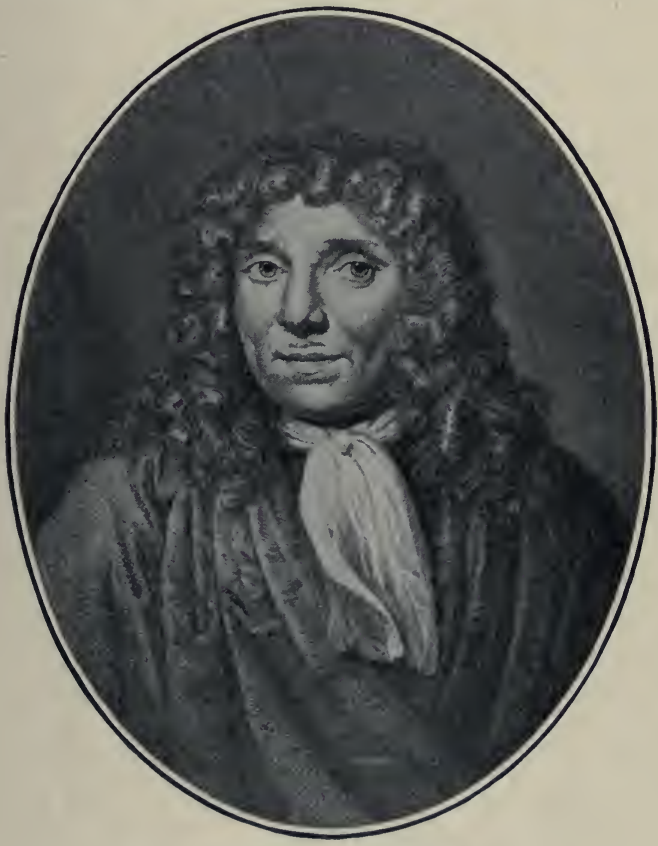

ANTONY VAN LEeUWENHOEK.

From the portrait by Verkolje, prefixed to the Epistola ad Soc. Reg. Angl., Leyden, 17 .

their optical defects, to bring a sufficicntly strong light to bear upon the object, and to focus the lens. When he wished to send out his preparations for examination by others, he found it best to fix the objects in the 
focus, and to provide each with a separate lens. With such microscopes he managed to study and figure very minute objects, such as blood-corpuscles, spermatozoa, and bacteria. The spermatozoa were brought under his notice by a young Dutch physician named Hamm; but it was Leeuwenhoek's account of them, and his daring theory of their physiological rôle, which gave them such celebrity. To Leeuwenhoek we owe the first discovery of the rotifers, the infusoria, Hydra, the yeast-cell, the bacteria, and the generation of aphids without male parents.

The tradition of the minute anatomists has never been lost, though we shall be unable to pursue it in these pages. Lyonet (see p. 6r) even surpassed Swammerdam in the elaborate finish of some of his insect-dissections.

\section{Early Notions about the Nature of Fossils.}

Throughout the sixteenth century naturalists held animated debates about the shells which are found far from the sea, and even on the top of high hills. Had they ever formed part of living animals or not? Such a question could hardly have been seriously discussed among simple-minded people; but the learned men of the sixteenth century were rarely simple-minded. They had been trained to argue, and argument could make it plausible that such shapes as these were generated by fermentation or by the influence of the stars. So prevalent were these doctrines that it entitles any early philosopher to the respect of later generations that he should have taken shells, bcnes, and teeth to be evidences of animal life. In this singular roll of honour we find the names of Cesalpini, Palissy, Scilla, Stenson, Hooke, and Woodward.

In England the struggle between philosophy and 
common-sense was long kept up. Dr. Ralph Cudworth of Cambridge taught that there is in nature a subordinate creative force of limited power and wisdom, to whose imperfections may be attributed the "errors and bungles" which now and then mar the work. To this subordinate creative force he gave the name of "vegetative soul," or "plastic nature." None but Cambridge men, it would appear, felt the weight of Cudworth's reasoning ; but several of these, and especially John Ray and Martin Lister, defended his conclusions in published treatises. Lister, in a chapter devoted to " cochlites," or shell-shaped stones, pointed out that they differ from true shells in being of larger size, in occurring far from the sea, in being formed of mere stony substance, and in being often imperfect. Some naturalists had conjectured that the living animals of the cochlites still exist at great depths in the sea, but Lister evidently thought otherwise.

In the eighteenth century the belief that fossils are the remains of actual animals and plants more and more prevailed, the death and sealing up of the organisms being generally attributed to Noah's flood. The occurrence of fossils on high mountains seemed so strong a confirmation of the Biblical narrative that Voltaire was driven to invent puerile explanations in order to dispel an inference so unwelcome to him. By the end of the century most naturalists accepted the doctrine that the great majority of fossils are the remains of organisms now extinct-a doctrine which was enforced by the remarkable discoveries of Cuvier (see p. 93). Nearly at the same time William Smith established the

- Ray came at last to believe that tossils were the remains of actual organisms, but he was still much hampered by his theological views. 
important truth that almost every fossil marks with considerable precision a particular stage in the earth's history.

\section{Comparative Anatomy : the Study of Biological Types.}

Between 1660 and 1740 the scope of natural history became sensibly enlarged. System had been hitherto predominant, but the systems had been partial, treating the vertebrate animals and the flowering plants with as much detail as the state of knowledge allowed, but almost ignoring the invertebrates and the cryptogams. System was now studied more eagerly than ever by such naturalists as Ray and Linnæus, but new aspects of natural history were considered, new methods practised, new groups of organisms included. Many remarkable vertebrates were anatomically examined for the first time. Claude Perrault and his colleagues of the Académie des Sciences dissected animals which had died in the royal menagerie, and compared the parts and organs of one animal with those of another; Duverney compared the paw of the lion with the human hand; in England Tyson studied the anatomy of the chimpanzee, porpoise, opossum, and rattlesnake, searching everywhere for the transitions which he believed to connect all organisms, and to form "Nature's Clew in this wonderful labyrinth of the Creation." The new microscopes helped to bring the lower and smaller animals into notice. From 1669, when Malpighi described the anatomy and life-history of the silkworm, a succession of what we now call biological types were studied; among these were many invertebrates. Edmund King and John Master contributed to Willis's treatise De Anima Brutorum (1672) the anatomies of the oyster, crayfish, and earthworm, 
all illustrated by clear and useful plates. Heide ( 1683 ) wrote an account of the structure of the edible mussel (Mytilus), in which mention is made of the ciliary motion in the gill; Poupart (I706) and Méry (I710) wrote accounts of the pond-mussel (Anodon). Swammerdam's elaborate studies of insects and their transformations were followed up by a long succession of memoirs by Frisch in Germany, Réaumur in France, and (shortly after the close of the period now under discussion) De Geer in Sweden. The extraordinary diligence and power of Swammerdam and Réaumur give a very prominent place in the biology of the seventeenth and eighteenth centuries to the structure and life-histories of insects. The great generalisations of comparative anatomy do not belong to this period; nevertheless, sagacious and luminous remarks are not wanting.

\section{Adaptations of Plants and Animals : Natural Theology.}

Natural adaptations and some of the problems which they suggest were much studied during this period. Bock and Cesalpini had discussed still earlier the mechanisms of climbing plants, aquatic plants, and plants which throw their seeds to a distance. Swammerdam figured, not for the first time, the sporangia and spores of a fern; Hooke the peristome of a moss. The early volumes of the Académie des Sciences contain many studies of natural contrivances. Perrault described the retractile claw of the lion, the pointed papillæ on its tongue, the ruminant stomach and the spiral valve of a shark's intestine. He improved upon Hooke's account of the structure of a feather, and his magnified figures of a bit of an ordinary quill and of a bit of an ostrich-plume might be inserted into any 
modern treatise on animal structure. ${ }^{I}$ Poupart followed the later stages of the development of a feather. Méry gave a minute yet animated description of the woodpecker's tongue, explaining how it is rendered effective for the picking up of insects, how it is protruded and retracted, how it is stowed away when not in use. Tournefort figured the oblique fibres of a leguminous pod, which he called muscles, and showed how they twist the valves and squeeze out the seeds.

Natural theology was much in the thoughts of the naturalists who studied and wrote between 1660 and 1740. Ray discoursed upon the Wisdom of God as manifested in the Creation. Swammerdam regularly closed the divisions of his Biblia Natura with expressions of pious admiration. A long list of books expressly devoted to the same theme might be given. ${ }^{2}$ One weakness of the natural theologians was their habit of looking upon the universe as existing for the convenience of man. Still more fatal was the partiality with which they stated the facts. While they dwell upon the adaptations which secure the welfare of particular animals or plants, they are silent about the sufferings caused by natural processes.

\section{Spontaneous Generation.}

During many ages every naturalist thought that he had ample proof of the generation without parents of animals and plants. He knew that live worms appear in tightly-closed flasks of vinegar; that grubs may be found feeding in the cores of apples which show no external marks of injury; and that weeds spring up in

- The second of the two has actually been so treated, but with. out mention of Perrault's name.

2 See Krause's Life of Erasmus Darwin. 
gardens where nothing of the sort had been seen before. Certain kinds of animals and plants are peculiar to particular countries; what more likely than that they should be the offspring of the soil? Fables and impostures supported what all took to be facts of observation. The great name of Aristotle was used to confirm the belief that insects were bred from putrefaction; eels and the fishes called Aphyæ from the mud of rivers. A belief in a process of transmutation was often combined with a theory of spontaneous generation. Francis Bacon not only held that insects were born of putrefying matter, but that oak boughs stuck in the earth produced vines.

Towards the end of the seventeenth century it occurred to one inquiring mind that a particular case of spontaneous generation, which had been accepted by everybody without hesitation, was capable of a less mysterious explanation. Francesco Redi (1626-1698), physician to the Duke of Tuscany, published in 1668 an account of his experiments on the generation of blow-flies. He found that the flesh of the same animal might yield more than one kind of fly, while the same fly might be hatched from different kinds of flesh. He saw the flies laying their eggs in flesh, and dissected eggs out of their ovaries. When he kept off the flies by gauze the flesh produced no maggots, but eggs were laid on the gauze. Redi concluded that flies are generated from eggs laid by the females. He also studied insect-galls, and the worms which feed on growing seeds. Like earlier observers, he was baffled by finding live grubs in galls or nuts which were apparently intact, and by the parasitic worms which are now and then found in the brain-case and other closed cavities of quadrupeds. Such instances led him to jump at the 
supposition of a "vivifying principle," which generated living things of itself-a supposition contrary to the truer doctrine which he taught elsewhere. Vallisnieri was able to explain how the egg is introduced into the rose-gall, which a little later shows no mark of injury ; while Malpighi examined the young nut and found both hole and egg. How parasitic worms reach the braincase of the sheep could be explained only in a later age. Meanwhile Swammerdam, Leeuwenhoek, Réaumur, and many other special students confirmed and extended Redi's experiments on the blow-fly ; and every fresh instance of normal generation in a minute organism did something to weaken the belief in spontaneous generation.

Late in the eighteenth century that belief revived in a form less easy of refutation. Leeuwenhoek had discovered that organic matter putrefying in water often yielded abundance of microscopic organisms of the most diverse kinds, many of which could resist drying in air and resume their activity when moistened again. Buffon, ever ready with a speculative explanation, maintained that such minute organisms were spontaneously generated, and that they were capable of coalescing into bodies of larger size and more complex structure. Needham supported Buffon's theories by experiments. Taking infusions of meat, corking them, and sealing them with mastic, he subjected them to a heat which he thought intense enough to destroy life; after an interval the microscope revealed an abundance of living things which he affirmed to have been generated from dead matter. Spallanzani repeated Needham's experiments with stricter precautions, sealed his flasks by fusing their necks in a flame, and then immersing them in boiling water until they were heated 
throughout. The infusions in such flasks remained limpid; no scum formed on the surface; no bad smell was given off when they were opened; and no signs of life could be detected by the microscope. To meet the objection that the vegetative force of the infusions had been destroyed by long heating he simply allowed air to enter, when the micro-organisms quickly reappeared. Spallanzani's methods, though far better than any which had been employed before, are not quite unimpeachable, and could not be relied upon in an atmosphere rich in germs; but they sufficed to create a strong presumption that life is set up in infusions by germs introduced with the air.

This was by no means the end of the controversy, which broke out again and again until it was laid to rest, whether finally or otherwise it would be unwise to predict, by the experiments of Pasteur.

\section{The Natural History of John Ray.}

The sixteenth, seventeenth, and eighteenth centuries each possessed at least one naturalist of wide learning and untiring diligence, who made it his care to collect information concerning all branches of natural history, to improve system, and to train new workers. Gesner, Ray, and Linnæus occupied in succession this honourable position.

Ray was originally a fellow of Trinity College, Cambridge, who had risen into notice by proficiency in academical studies. He then became inspired by the hope of enlarging the knowledge of plants and animals, and of producing what we should now call a descriptive fauna and flora of Great Britain. His plan contemplated close personal observation, travels at home and abroad, and the co-operation of pupils and friends. 


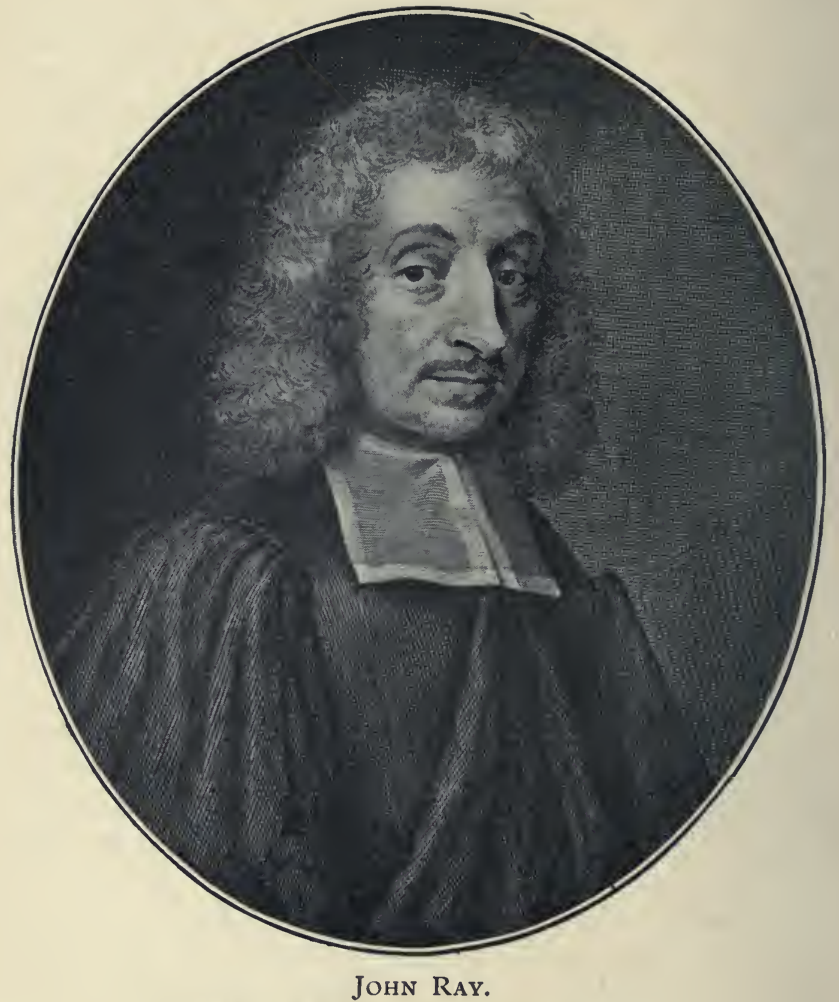

From an old engraving of the portrait by Faithorn. 
His chief assistant was Francis Willughby, a young man of wealth and good family; while Martin Lister, a Cambridge fellow, who had already laboured at natural history with good effect, undertook an independent share in the work. Ray wisely began with what lay close at hand, and published a catalogue of the plants growing around Cambridge. This was not a mere list of species, but a note-book charged with the results of much observation and reading. Journeys in quest of fresh material were begun. Then Ray's well-laid scheme was disconcerted by calamities which would have overwhelmed a less resolute man. He was driven from Cambridge by the Act of Uniformity, and forced to serve for years as a tutor in private families. When this servitude came to an end his only livelihood was a small pension, bequeathed to him by Willughby, on which he lived in rustic solitude. Willughby was cut off at the age of thirty-six, having accumulated much information but completed nothing. Lister became a fashionable physician, to whom natural history was little more than an elegant diversion. The whole burden of the enterprise fell upon Ray, who manfully bore it to the end. He completed his own share of the work, prepared for the press the imperfect manuscripts of Willughby, and before he died was able to fulfil the pledge which he had given forty years before in the prosperity of early manhood. It is needless to say that the natural history of Britain, executed in great part by a poor and isolated student, fell far short of what Ray might at one time have reasonably expected to accomplish.

Ray, like other early naturalists, saw that a methodical catalogue of species, arranged on some principle which could be accepted in all times and in all countries, was indispensable to the progress of natural history, 
and such a catalogue formed an essential part of his plan. Perhaps he was a little deficient in that discernment of hidden affinities which has been the gift of great systematisers, but his industry, learning, and candour accomplished much. Quadrupeds, birds, reptiles, fishes, insects, and plants of every sort were reviewed by him. British species naturally received special attention, but Ray did not fail to make himself acquainted with the natural productions of foreign countries, partly by his own travels, and partly by comparing the descriptions of explorers. He seized every opportunity of investigating the anatomy and physiology of remarkable animals and plants, and attended to the practical uses of natural history. British naturalists owed to him the first serviceable manuals for use in the field.

Ray was the first botanist who formally divided flowering plants into Monocotyledons and Dicotyledons. It was only natural that he should now and then have misplaced plants whose general appearance is deceptive (lily of the valley, Paris, Ruscus, etc.). $\mathrm{He}$ was perhaps the first to frame a definition of a species; but here his success, as might be expected, was not great. A species was with him a particular sort of plant or animal which exactly reproduces its peculiarities generation after generation. Any plant, for example, which comes up true from seed, would according to Ray constitute a species. By this definition many races of plants which are known to have been produced in nurseries would rank as true species.

\section{The Scale of Nature.}

No one can closely examine a large number of plants and animals without perceiving real or imaginary 
gradations among them. The gradation, shreres, monkeys, apes, man, is not very far from a real genealogical succession, confirmed by structural and historical proofs. The gradation, fish, whale, sheep, on the other hand, though it seemed equally plausible to early speculators, is not confirmed by structure and history. In the age of Aristotle and for long afterwards the ostrich was believed to be a connecting link between birds and mammals, because it possessed, in addition to obvious bird-like features, a superficial resemblance to a camel (long neck, speed in running, desert haunts, and a rather imaginary resemblance in the toes). Sedentary, branching zoophytes were quoted as intermediate between animals and plants; corals and barnacles as intermediate between animals or plants and stones. Aristotle was convinced of the continuity of nature ; his scale of being extended from inanimate objects to man, and indicated, as he thought, the effort of nature to attain perfection. Malpighi traced analogies between plants and animals, identifying the seed and egg, as many had done before him, assuming that viviparous as well as oviparous animals proceed from eggs, and comparing the growth of metals and crystals with the growth of trees and fungi. Leibnitz believed that a chain of creatures, rising by insensible steps from the lowest to the highest, was a philosophical necessity. Buffon accepted the same conclusion, and affirmed that every possible link in the chain actually exists. Pope reasoned in verse about a "vast chain of being," which reaches from God to man, and from man to nothing. The eighteenth century was filled with the sound.

Bonnet in 1745 traced the scale of nature in fuller detail than had been attempted before. He made 
Hydra a link between plants and animals, the snails and slugs a link between mollusca and serpents, flying fishes a link between ordinary fishes and land vertebrates, the ostrich, bat, and flying fox links between birds and mammals. Man, endowed with reason, occupies the highest rank; then we descend to the half-reasoning elephant, to birds, fishes, and insects (supposed to be guided only by instinct), and so to the shell-fish, which shade through the zoophytes into plants. The plants again descend into figured stones (fossils) and crystals. Then come the metals and demimetals, which are specialised forms of the elemental earth. Water, air, and fire, with perhaps the æther of Leibnitz, are placed at the bottom of the scale.

In Bonnet's hands the scale of nature became an absurdity, by being traced so far and in so much detail. It was not long before a reaction set in. The great German naturalist, Pallas, in his Elenchus Zoophytorum (1766) showed that no linear scale can represent the mutual relations of organised beings; the branching tree, he said, is the appropriate metaphor. Cuvier taught that the animal kingdom consists of four great divisions which are not derived one from another, and his authority overpowered that of Lamarck, who still maintained that all animals form a single graduated scale. A complete reversal of opinion ensued, so complete that at length the theologians, who had once seen in the scale of nature a proof of the wisdom of Providence, were found fighting with all their might against the insensible gradations which, according to Darwin's Origin of Species, must have formerly connected what are now perfectly distinct forms of life.

The eighteenth-century supporters of continuity in nature were not merely wrong in picturing the organised 
world as a simple chain or scale. They were also wrong in assuming that all the links or steps still exist. We can now see that vast numbers are irrecoverably gone. It is a safe prophecy that the filiation of species will never be grasped by the intelligence of man except in outline, and even an outline which shall truly express the genetic relations of many chief types is unattainable at present.

\section{The Sexes of Flowering Plants.}

As soon as men began to raise plants in gardens, or even earlier, they must have remarked that plants produce seeds, and that seeds develop into new plants. The Greeks (Empedocles, Aristotle, Theophrastus) recognised that the seed of the plant answers to the egg of the animal, which is substantially though not literally true. None of the three understood that a process of fertilisation always, or almost always, precedes the production of seed. $\mathrm{Had}$ the date-palm, whose sexes are separate, and which has been artificially fertilised from time immemorial, been capable of cultivation in Greece, Aristotle would not have said that plants have no sexes, and do not require to be fertilised. His pupil, Theophrastus, knew only by hearsay of the male and female date-palms, and affirmed that both bear fruit. Pliny, three hundred years later, called pollen the fertilising substance, and gave it as the opinion of the most competent observers that all plants are of two sexes. The revivers of botany paid no attention to pollen or the function of the flower; it is more surprising that in the following century Malpighi, who had diligently studied the development of the plant-embryo, should give so superficial an account of the stamen and its pollen. About the same time Grew and Millington expressed their conviction that "the attire" (anthers) 
"doth serve as the male, for the generation of the seed." I A few years later Ray ${ }^{2}$ speaks of the masculine or prolific seed contained in the stamens. In 169I-4 Camerarius, professor at Tübingen, brought forward clear experimental proof that female flowers, furnished only with pistils, produce seeds freely in the neighbourhood of the male or staminate flowers, but fail to do so when isolated. He distinctly inferred that the anthers are male organs and the pistil the female organ. The claim set up on behalf of Linnæus that he demonstrated, or helped to demonstrate, the sexes of flowering plants has little foundation in fact. To make out such details of the process of fertilisation as the formation of pollen-tubes, the penetration of the ovules and the fusion of nuclei required the improved microscopes of the nineteenth century.

The almost universal presence both in plants and animals of a process of fertilisation is a fact whose physiological meaning we but imperfectly grasp. Modern research has shown that the pollen-tube is exceptional and confined to the flowering plants; the motile filament of cryptogams, analogous to the spermatozoon of animals, is no doubt a relatively primitive structure, which gives one of the strongest indications of the common origin of all forms of life.

x Grew's Anatomy of Plants, 1682. - Wisdom of God, $169 \mathrm{I}$. 


\section{PERIOD III.}

I $741-1789$

\section{Characteristics of the Period.}

THE chief historical events are the decline of the French monarchy, the French revolution, the rise of Prussia, the expansion of England, and the American Declaration of Independence. In the history of thought we remark the introduction of the historical or comparative method, which seeks to co-ordinate facts and to trace events to their causes. Science steadily grows in influence, and freethought wins many triumphs; this is the age of Voltaire, Rousseau, and the Encyclopædists, of David Hume, of the French economists and Adam Smith.

Systems of Flowering Plants : Linnæus and the Jussieus.

Linnæus is remembered as a man of great industry, enterprise, and sagacity, who was inspired from boyhood by a passion for natural history and spent a long life in advancing it. He was early recognised as a leader in more than one branch of the study.

L'Obel, Morison, and Ray had laboured to found a natural system of flowering plants, and it was they who laid the foundation upon which all their successors have built. The work did not, however, go steadily forward on the original plan. When Linnæus entered upon the scene the prevalent systems were only moderately natural, and far from convenient in practice. To place the undescribed species which poured in from North America and other distant countries was a difficult task, 
with which the universities and botanic gardens of Europe could but imperfectly cope. Linnæus, who had the instincts of a man of business, saw that botany was falling into confusion, and that the only remedy was a quick and easy method, which could be mastered in a few days and applied with certainty. No such method, he well knew, could take into account all the intricate affinities of plants, but to devise a perfect method required the labours of generations of botanists ; meanwhile a temporary expedient, full of faults it might be, would remove a pressing evil. Flowering plants had been arranged by the divisions of the ovary, or by the petals and sepals, with no very satisfactory results; it occurred to Linnæus to try the number of the stamens and styles. Any such method was bound to present many anomalies, associating plants which are only distantly related, and separating plants which are closely related; but some of the worst anomalies were avoided and some well-established families (Crucifers, Composites, Labiates) retained at the expense of symmetry. Not even the pressing need of simple definitions, which was allowed to spoil so natural a group as the Umbellifers, ${ }^{x}$ could induce Linnæus to place Ranunculus and Potentilla in the same class.

Linnæus gained currency for his system by connecting it with the newly accepted doctrine of sexes in plants. That doctrine was not conceived nor demonstrated by him (see p. 48), and it had, as we now see, no further connection with classification by stamens and styles than that it explained the almost universal occurrence of such parts in flowering plants. But Linnæus had persuaded himself that he had done more to establish

3 By associating with them a number of alien genera. 
the existence of sexes in plants than anybody else, and that the physiological importance of stamens and styles was a proof of their systematic value. Neither of these beliefs can stand inquiry, but both were extremely influential on contemporary opinion. The so-called Sexual System achieved an immense success everywhere but in France and Germany. Botanists of small experience were now able to say whether the plants which seemed to be new were really undescribed or not ; if undescribed, what was their appropriate place in the system. The congestion of systematic botany was relieved.

The great naturalist appealed to posterity by publishing the sketch of a natural system of flowering plants, which he accompanied by judicious expositions of the philosophy of classification. He had the permanent reform of systematic botany really at heart; he did not believe that his own Sexual System could be final; and he was glad to help in setting up a better one. To this end he united groups of genera into families which he did not pretend to define, being often guided only by an obscure sense of natural bonds of union. Bernard de Jussieu, one of the most patient and observant of systematists, devoted his life to the same task, and profited by the example of Linnæus. He published nothing, but found expression for his views in the arrangement of a botanic garden at Versailles. His ideas were afterwards developed by his nephew, A. L. de Jussieu, in the Genera Plantarum (1789).

Affinity became at length the avowed basis of every botanical system. No convenience in practice, no agreement or difference in habit, was knowingly permitted to override this mysterious property. What then is affinity? What are natural groups of animals and plants, and how do they arise? Until the year 
1859 no one could tell. The terse maxims of Linnæus helped to guide naturalists into the right road, but a single fact shows how inadequate they were. Linnæus emphatically and repeatedly declared his belief in the constancy of species. But if species were really constant, affinity between species must have been no more than a delusive metaphor; the resemblances between distinct species could not, on that supposition, be the effect of inheritance.

Linnæus' imperfect appreciation of the fundamental difference between a natural classification of living things and such classifications as man makes for his own practical ends is further revealed by his admission of a third kingdom of nature. ${ }^{x}$ Not only animals and plants, but rocks and minerals as well, had, he thought, their genera and species. The genus and species thereby become mere logical terms, independent of inheritance and of life itself.

Linnæus had a passionate love of order and clearness, enforced by an inexhaustible power of work. Hence he was able to serve his own generation with great effect, to methodise the labours of naturalists, to devise useful expedients for lightening their toil (such as his strict binomial nomenclature), ${ }^{2}$ and to apply scientific knowledge to the practical purposes of life. But the complexity of nature is not to be suddenly and forcibly reduced to order, and much of Linnæus' work had to be done over again in a different spirit. Cuvier furnishes a somewhat parallel case. Cuvier too was an indomitable worker. His power of organisation moved the wonder of Napoleon, and there has been no greater

The third kingdom of nature was taken from the alchemists.

2 The binomial nomenclature had been gradually coming in ever since the time of the Bauhins. 


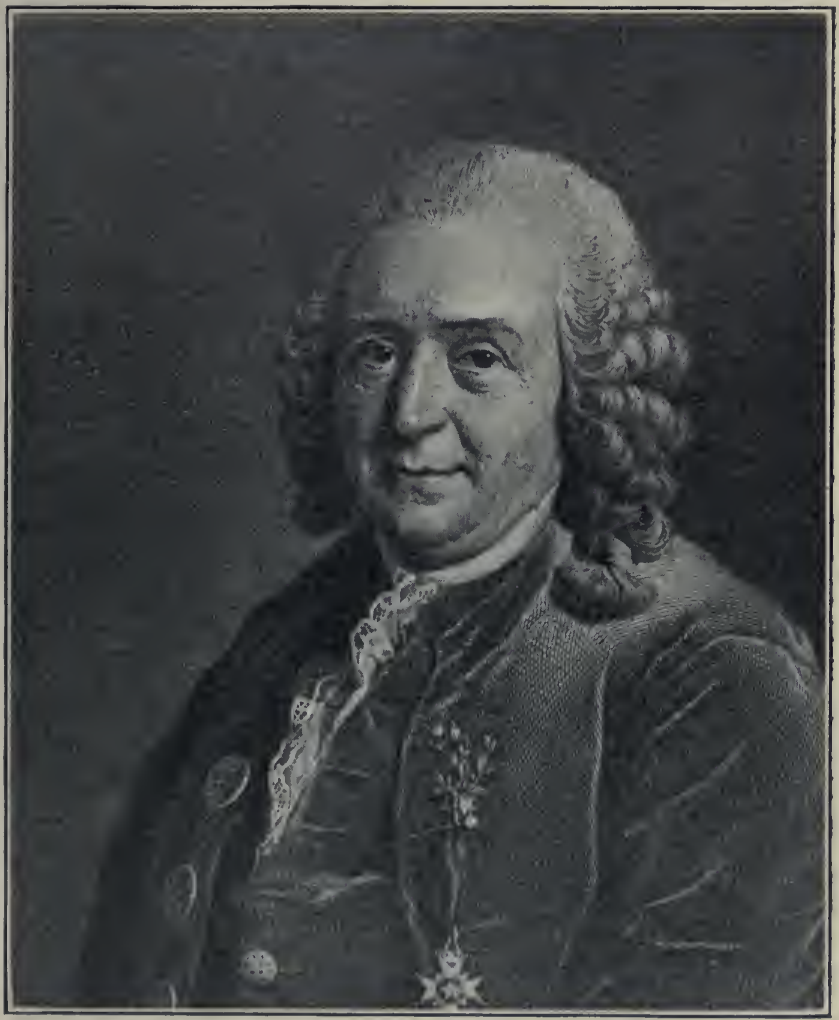

Carl von linné (Carolus linnaus).

From an engraving (1779) after the portrait by Roslin 
master of clear thought and clear expression. But, like Linnæus, Cuvier overlooked much that was already obscurely felt and clumsily worded by brooding philosophers, germs of thought which were destined to become all-powerful in the course of a generation or two. It must not be supposed that the labours of Linnæus and Cuvier were bestowed in vain. All that was really valuable in their writings has been saved, and biology will never forget how much it owes to their life-long exertions.

\section{Réaumur and the History of Insects.}

Réaumur was born to wealth, and made timely use of his leisure to study the sciences and win for himself a place among natural philosophers. His inclinations directed him first towards mathematics, physics, and, a little later, towards the practical arts. He took a leading part in a magnificent description of French industries, which had been undertaken by the Académie des Sciences. Not content with describing the processes in use, he perpetually laboured to improve them. The manufacture of steel, tin-plate, and porcelain, the hanging of carriages and the fitting of axles, the improvement of the thermometer, glass hives, and the hatching of fowls' eggs by artificial heat are among the many objects to which his attention was directed. Natural History gradually took a more and more promirent place in his studies, and a great History of Insects engaged the last years of his busy life.

Réaumur was neither an anatomist nor a systematist, at least he gained no distinction in either of these branches of biology. No biological laboratory had been dreamt of in his day; he lacked the manipulative skill of Swammerdam or Lyonet; he was no draughts- 
man, and had to engage artists to draw for him. One qualification of the first importance, however, he possessed in a high degree, the scientific mind. As he watched the acts of an insect, questions at once sagacious and practical suggested themselves in abundance, and these questions he set himself to answer in the best possible way-viz., by observation and experiment. In close attention to the activities of living things his ingenuity and patience found a boundless sphere of exercise. Moreover all that he had seen he could relate in a simple but picturesque manner, using the language familiar to the best French society in the generation next after Madame de Sévigné. Diffuse but clear, amusing but never frivolous, he won and kept the attention of a multitude of readers, the best of whom were incited to adopt his methods or to pursue inquiries which he had indicated. His greatest successes were won in observing and interpreting the natural contrivances of insects, the means by which they get their food and provide for their safety; their transformations, instincts, and societies. Kirby and Spence, which is still one of the best popular accounts of insects in English, is largely based upon Réaumur; so are other well-known treatises, in which the debt is less frankly acknowledged. Réaumur greatly enlarged the knowledge of all kinds of insects except the beetles and Orthoptera, which he did not live to describe, and to this day his Histoire des Insectes is a work of fundamental importance, with which every investigator of life-histories is bound to make himself acquainted.

No abstract of Réaumur's Histoire des Insectes is possible, but we may at least give one example of his mode of treatment. Let us select his account of the proboscis of a moth, the first full account that was ever 
given. He tells us that all moths have not an effective proboscis, though he does not explain how some of them can dispense with what seems so necessary an organ; this omission has been made good by later entomologists. The proboscis, he goes on, springs from the head, just between the compound eyes. When at rest, it takes up very little room, for it is spirally rolled, like a watch spring; in some cases it makes as few as one and a half or two turns, in others as many as eight or ten ; the base is often concealed by a pair of hairy palps, which serve as feelers. Careful study of a moth as she flits from flower to flower shows that she alights on the plant, unrolls her proboscis, passes it into the corolla, withdraws it, perhaps coils it for an instant, and then plunges it again into the tube. When this manœuvre has been repeated several times, the moth flies off to another flower.

Some moths have a tape-like proboscis; in others it is cylindrical. It can be made to protrude by gentle pressure on the head, or be unrolled by a pin passed into the centre of the spire ; it is composed of innumerable joints, and tapers from the base to the tip. When forcibly unrolled, it often splits lengthwise into halves. At the time of escape from the chrysalis the halves are always free, and they require careful adjustment in order that a continuous sucking-tube may be obtained. A newly emerged moth may be seen to roll and unroll its proboscis repeatedly, until at last the halves cohere in the proper position. Sometimes they begin to dry before the operation is completed, the half-tubes get curled, and then the unfortunate moth becomes incapable of feeding at all. Each half is a demi-canal, whose meeting edges interlock by minute hooks. The mechanism reminds Réaumur of that which connects 
the barbs of a feather; in both cases the hooks can be adjusted rapidly and completely by stroking from base to tip, and in both a water-tight junction is obtained. Besides the central canal, along which fluids are sucked up, there are lateral canals (tracheæ) filled with air.

Réaumur was careful to correct his anatomical studies by close observation of the live insect. He reared an angle-shades moth, which he kept several days without food. When he saw it repeatedly extending its proboscis, he put near it a piece of sugar. The moth at once began to suck, and became so absorbed in satisfying its hunger that it allowed Réaumur to carry it on a sheet of paper to a window and to examine it closely with a lens. The proboscis was sometimes extended for several minutes at a time, and then rolled up for an instant ; its tip was either employed in exploring the surface or closely applied to the sugar. By means of the lens a slender column of liquid was seen to pass along the central canal towards the head. Now and then, however, a limpid fluid was seen to pass down the proboscis; this was the saliva which was used to moisten the sugar, and then sucked up again.

\section{The Budding-out of New Animals (Hydra): another Form of Propagation without Mating (Aphids).}

In the year I744 a young Genevese, Abraham Trembley, tutor in the family of Bentinck, who was then English resident at the Hague, rose into sudden fame by a solid and well-timed contribution to natural history. Trembley and his pupils used to fish for aquatic insects in the ponds belonging to the residence, and in the summer of $\mathrm{I} 740$ he happened to collect some water-weeds, which he put into a glass vessel and set in a window. When the floating objects had come to 
rest, a small green stalk, barely visible to the naked eye, was found attached to one of the plants. From one end of the stalk filaments or tentacles were seen to project, and these moved slowly about. When the vessel was shaken the stalk and tentacles contracted, but soon extended themselves again. Was this object a plant or an animal? Its shape and colour were those of a plant, and sensitive plants were known which drooped when touched or shaken. Further observation showed that it could move from place to place, which favoured the animal interpretation. Trembley determined to cut the stalk in two; if the halves lived when separated the fact would favour the plant-theory. The halves at first gave no signs of life beyond occasional contraction and expansion, but after eight days small prominences were seen on the cut end of the basal half. Next day the prominences had lengthened; on the eleventh day they seemed to be growing into tentacles. Before long eight fully formed tentacles were visible, and Trembley had two complete specimens in place of one ; both were able to move about.

After four years of observation a handsome quarto volume was published, which told the history of "The freshwater Polyp," a name suggested by Réaumur; the Latin name of Hydra was given by Linnæus. Hydra had been discovered and slightly described forty years before by Leeuwenhoek, who had seen two young polyps branching from one parent and spontaneously becoming free. Trembley made out all that a simple lens, guided by a skilful hand and a keen eye, could discover. Thirteen plates were admirably engraved by another amateur, Pierre Lyonet, who was in all respects a fit companion for Trembley. It was proved that Hydra preyed upon living animals, especially upon the 
Daphnia or water-flea. When it was well nourished it branched spontaneously again and again, forming a compound mass made up of scores or even hundreds of polyps, all connected with a single base. The power of locomotion and the power of devouring prey were held to settle the animal nature of Hydra, a decision to which zoologists have ever since adhered. Lyonet went on to try the effect of division upon some common freshwater worms, and found that each part grew into a complete worm. Artificial division is not indispensable; in the worm called Nais division takes place spontaneously at certain seasons, one segment dividing repeatedly, so as to form the segments of a complete new individual. The process may be repeated until a chain of worms is produced, which at length breaks up. ${ }^{\text {I }}$

A nail was thus driven in a sure place. The conception of an animal was enlarged, for it was shown that an animal may branch and multiply in a way hitherto supposed to be peculiar to plants. The old connecting links between animals and plants (zoophytes, sponges, etc.) had never been really investigated; no one knew what sort of organisms formed or inhabited their plantlike skeletons. But Hydra, thanks to Trembley's description, furnished a clear example of an animal which possessed some of the attributes of a plant. Forms more ambiguous than Hydra, such as Volvox and Euglæna, were ultimately to make the distinction between animal and plant very uncertain and shadowy. It was Hydra that gave the first clue to the structure of

- This discovery is usually attributed to Bonnet, but the testimony of Réaumur (Hist. des Insecles, Vol. VI., p. Ivi.) and of Trembley (Hist. des Polypes d'eau douce, p. 323) is decisive in favour of Lyonet. 
the zoophytes, and dispelled the false notion that corals are plants, bearing flowers, fruits, and seeds.

Baer $^{I}$ has remarked that Trembley's discovery appreciably modified the teaching of physiology by showing that an animal without head, nerves, senseorgans, muscles, or blood may perceive, feed, grow, and nove about.

At the time when Trembley was demonstrating the asexual propagation of Hydra, Bonnet (supra, p. 45) was demonstrating the asexual propagation of aphids. Both naturalists were natives of Geneva, and both, as well as their associate Lyonet, were in a sense pupils of Réaumur, who not only set them an admirable example, but directed their attention to promising researches and discussed with them the conclusions which might be drawn. Réaumur's experience had seemed to confirm Leeuwenhoek's statement (supra, p. 34) that aphids produce young alive, even though no males are to be found among them; but unlucky accidents defeated his intention to confirm it by experiment, and when Bonnet asked him to suggest a piece of work Réaumur gave him the aphid problem. ${ }^{2}$

Bonnet filled a flower-pot with moist earth, introduced a food-plant together with a single new-born aphid, and covered all up with a bell-jar. In twelve days the aphid produced its first young one; in a month ninety-five had been born from the same unfertilised parent. As many as five generations were obtained without the intervention of a male, each successive parent having been isolated from the moment of its birth. It was, however, discovered, apparently by

I Reden, Vol. I., pp. 109, I54.

2 Traité d'Insectologie, première partie. Two vols. 12 mo. Paris, 1745 . 
Lyonet, that though viviparous reproduction without males went on regularly so long as food was plentiful, males appeared towards the end of summer, and fertilised the eggs which were destined to outlast the winter.

The aphids added a new and peculiar example to the known cases of asexual propagation (plants and Hydra). Much discussion followed, but the physiology of that age (and the same is true of the physiology of our own age) was unable to reveal the full significance of the observed facts. Insects have since furnished many instances of unfertilised eggs which yield offspring. One such instance was already recorded, though neither Leeuwenhoek, Réaumur, nor Bonnet knew of it. In the year I7or Albrecht of Hildesheim placed a pupa in a glass vessel and forgot it. A moth hatched out and laid eggs, from which a number of caterpillars issued.

Lyonet, whom we have more than once had occasion to mention, afterwards became celebrated as the author of one of the most laborious and beautiful of insectmonographs. The structure of the larva of the goatmoth was depicted by him in eighteen quarto plates, crowded with detail.

\section{The Historical or Comparative Method: Montesquieu and Buffon.}

About the middle of the eighteenth century we remark the introduction of a new, or almost new, method of investigation, which was destined to achieve great results. Hitherto many men had been sanguine enough to believe that they could think out or decide by argument hard questions respecting the origin of what they saw about them. It was easier, but not really more 
promising, to resort to ancient books which contained the speculations of past generations of thinkers. Now at last men set themselves to study what is, and by the help of historical facts to discover how it came to be. The new method was first applied to the institutions of human society, but was in the end extended to the earth, life on the earth, and a multitude of other important subjects.

Most writers call this method historical, because history is the chief means by which it seeks to trace causes. Others call it genetic, because it goes back, whenever it can, to origins. It might also be called comparative, because it compares, not only things which are widely separated in time, but also things which are separated in space, things which differ in form or ten. dency because they have a common origin, and things which differ in origin because they have a common form or tendency. Whether the institutions, arts, and usages of mankind, or the species of plants and animals, are in question, the study of history, together with the comparative study of what now exists, results in increased attention to development, and this again brings to light the continuity of all natural agents and processes-continuity in time and continuity among co-existences. Since the new method has succeeded in tracing the causes of many phenomena which once seemed to obey no law, it has done much to strengthen the belief in universal causation.

Down to the middle of the eighteenth century the book of Genesis had been almost unanimously accepted in Europe as the only source of information concerning the origin of the world, of man, of languages, of arts and sciences. The whole duration of the world was restricted to so brief a space that slow development 
was impossible, and it was assumed that early history of every kind must be miraculous. ${ }^{x}$

Montesquieu (Esprit des Lois, I748) was the first to exhibit on an impressive scale the power of the historical method. Natural development, determined by unalterable conditions, was with him the key to the right understanding of the past. It is well known that here and there a great thinker had before Montesquieu framed something like the same conception. The Politics of Aristotle ${ }^{2}$ and Vico's study of the historical evolution of the Roman law (I725) are memorable anticipations. By I748, the date of the Esprit des Lois, or 1749 , the date of Buffon's first volumes, which come next before us, Newton's Principia had made students of physics and astronomy practically familiar with the notion of universal causation.

Buffon's place in the history of science is that of one who accomplished great things in spite of weaknesses peculiarly alien to the scientific spirit. It was mainly he who, by strenuous exertions and largely at his own cost, transformed the gardens from which the king's physicians used to procure their drugs into what we now know as the Jardin des Plantes. By the untiring labours of fifty years he produced a Natural History in

x In circles untouched by general European thought such beliefs lasted much later. Sir Francis Galton (Memories of My Life, p. 67) says: "The horizon of the antiquarians was so narrow at about the date (1840) of my Cambridge days that the whole history of the early world was literally believed, by many of the bestinformed men, to be contained in the Pentateuch. It was also practically supposed that nothing more of importance could be learnt of the origin of civilisation during classical times than was to be found definitely stated in classical authors."

3 "If anything could disentitle Montesquieu's Esprit des Lois to the proud motto, Prolem sine malre creatam, it would be its close relationship to the Politics." (A. W. Benn's Greek Philosophers, Vol. II., p. 429.) 
thirty-six volumes crowded with plates. Having won for himself a place side by side with Montesquieu and Gibbon, he employed it to direct attention to the larger questions of biology and geology. $\mathrm{He}$ was a pronounced freethinker, who promulgated bold views with a dexterity which saved him from condemnation by the theological tribunals. When his opinions were declared to be contrary to the teaching of the Church, he printed a conciliatory explanation, but never cancelled the passages objected to, which continued to appear in a succession of editions. His deficiencies, we must admit, were serious. He was a poor observer (partly because of short sight), and had no memory for small details. His enemies were able to taunt him with absurd mistakes, such as that cows shed their horns. He alienated the two foremost naturalists of the eighteenth century, Linnæus and Réaumur, by ignorant and scornful criticisms. His strong propensity to speculation, insufficiently checked by care to verify, might have brought him under the sarcastic remark of Fontenelle, that ignorance is less apparent when it fails to explain what is, than when it undertakes to explain what is not.

Buffon's fame is not seriously impaired by the fact that his great work is no longer read except by those who study the course of scientific thought. Few productions of the human intellect retain their value after a bundred years, and scientific treatises become obsolete souner than others. It is consoling to recollect that, if their energy is quickly dissipated, it is at least converted into light.

In a history of biology Buffon is naturally a more important figure than Montesquieu. Buffon had imbibed evolutionary views from the Protogae of Leibnitz, which in turn made use of certain hypotheses of 
Descartes. ${ }^{x}$ The Histoire Naturelle inclines to some theory of evolution, especially in the later volumes. At first Buffon teaches that species are fixed and wholly independent of one another ; some years later he is ready to believe that all quadrupeds may be derived from some forty original forms, while in a third and subsequent

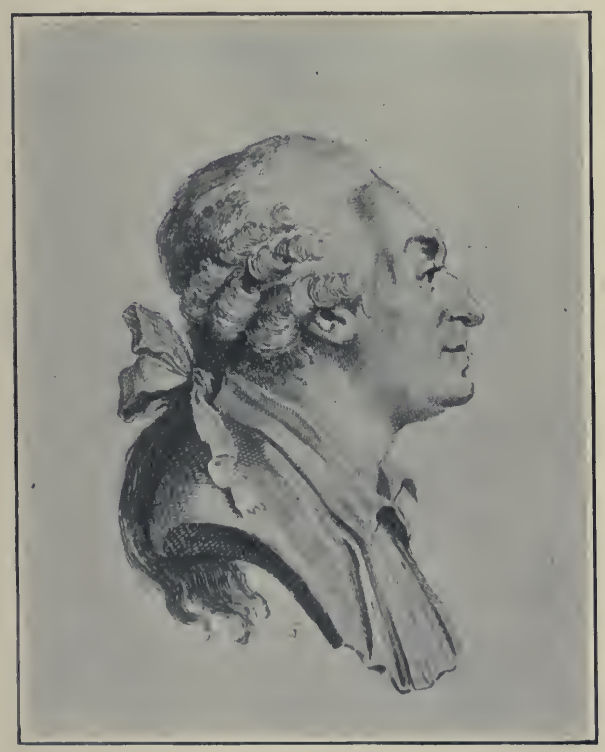

Georges Louis Leclerc, Comte de Buffon.

passage he puts the question whether all vertebrates may not have had a common ancestor. He does not shrink from saying that one general plan of structure

- For an account of other early hypotheses of the same kind the reader may refer to Edward Clodd's Pioneers of Evolution. 
pervades the whole animal kingdom-a belief that he could never have adequately supported by facts ; Baer long afterwards $(1828)$ searched in vain for evidence on this very point, while Darwin in 1859 admitted that his arguments and facts only proved common descent for each separate phylum of the animal kingdom ; ${ }^{I}$ he inferred from analogy that probably all the organic beings which have ever lived on this earth have descended from some one primordial form. ${ }^{2}$ Elsewhere Buffon makes bold to declare that Nature in her youthful vigour threw off a number of experimental forms of life, some of which were approved and adopted, while others were allowed to survive in order to give mankind a wider conception of her projects. There is generally some gleam of truth in Buffon's most fantastic speculations, but we often wish that he could have attended to the warning of Bossuet: "Le plus grand dérèglement de l'esprit est de croire les choses parce qu'on veut qu'elles soient."

Against all his shortcomings we must set the fact that Buffon strove to interpret the present by the past, the past by the present, geology by astronomy, geographical distribution by the physical history of the continents. One of his maxims expresses the fundamental thought of Lyell's Principles of Geology: "Pour juger de ce qui est arrivé, et même de ce qui arrivera, nous n'avons qu'à examiner ce qui arrive."

Hard-and-fast distinctions are the marks of imperfect theory. Early philosophers distinguished hot and cold, wet and dry, light and dark, male and female, as things different in kind. In later times organic and inorganic, animal and vegetable, the activities of matter and the activities of mind, have been sharply separated. But as

I Life and Letters, Vol. II., p. 212.

$=$ Origin of Species, ed. i., p. 484 . 
knowledge increases these distinctions melt away; it is perceived that the extreme cases are either now connected by insensible gradations, or else spring historically from a common root. Hutton, Lyell, and their successors have made it clear that the history of the earth calls for no agents and no assumptions beyond those that are involved in changes now going on ; the present is heir by unbroken descent to the past. Continuity has been established between all forms of energy. Even the chemical elements, once the emblems of independence, give indications that they too had a common origin. The nebular hypothesis, which has been steadily rendered more probable by the scientific discoveries of two centuries, traces all that can be perceived by the senses to a homogeneous vapour, and lays the burden of proof on those who believe that continuity has its limits. Every history, whether of planetary systems, or of the earth's crust, or of human civilisations, religions, and arts, is recognised as a continuous development with progressive differentiation.

\section{Amateur Students of Living Animals.}

A history of biology would be incomplete which took no notice of every-day observations of the commonest forms of life. Some of the best are due to the curiosity of men with whom natural history was no more than an occasional recreation. William Turner (a preacher, who became Dean of Wells), Charles Butler (a schoolmaster), Caius and Lister (physicians), Claude Perrault (a physician and architect), Méry and Poupart (surgeons), Frisch (a schoolmaster and philologue), Lyonet (an interpreter and confidential secretary), Roesel (a miniature painter), Henry Baker (a bookseller, who gained a competence by instructing deaf mutes), 
Leroy (ranger to the King of France), Stephen Hales, Gilbert White and William Kirby (country parsons), and William Spence (a drysalter) were all amateurs in natural history. To this list we might add Willughby, Ray, Leeuwenhoek, Réaumur, De Geer, Buffon, the Hubers, and George Montagu, who were either so fortunate in their worldly circumstances or so devoted to science as to make it their chief, or even their sole pursuit, though they did not look to it for bread. A large proportion of the naturalists whose names have been quoted occupied themselves with the habits and instincts of animals, and biology has been notably enriched by their observations. To Englishmen the most familiar name is that of Gilbert White, in whom were combined thirst for knowledge, exactness in description, and a feeling for the poetry of nature.

White used his influence to encourage what may be called live natural history, which, as he understood it, "abounds in anecdote ${ }^{x}$ and circumstance." He bids his correspondents to "learn as much as possible the manners of animals; they are worth a ream of descriptions." His example has done more than his exhortations. He focusses a keen eye upon any new or little-known animal, such as the noctule, the harvestmouse, or the mole-cricket ; detects natural contrivances little, if at all, noticed before, such as the protective resemblance of the stone-curlew's young; divells upon the practical applications of natural history, such as the action of earthworms in promoting the fertility of soils; and combines facts which a dull man would be careful to put into separate pigeon-holes, such as the different

I White uses anecdote in the old sense, meaning by it a piece of unpublished information. 
ways in which a squirrel, a field-mouse, and a nuthatch extract the kernels of hazel-nuts.

The many amateurs of the eighteenth century naturally demanded books written to suit them, and illustrated books with coloured plates, coming out in parts, found a ready sale. Some were devoted to insects, others to microscopic objects. In accordance with prevalent belief, the writers made a point of tracing the hand of Providence in the minutest organisms ; many popular treatises were altogether devoted to natural theology. Some few of these natural history miscellanies contained original work, which has not yet lost its interest. The best is Roesel's Insecten-belustigungen (four vols. 4to., I746-6r), memorable among other things for containing the original description of Amœba. For English readers Henry Baker wrote The Microscope Made Easy (1743) and Employment for the Microscope (I753).

\section{Intelligence and Instinct in the Lower Animals.}

The period with which we are now concerned (I74II789) initiated the profitable discussion of the mental powers of animals. We are unable for lack of space to follow the investigation from period to period, and must condense into one short section whatever its history suggests.

In the year 1660 Aristotelians were still discoursing about the vegetative and sensitive souls which bridged the gulf between inanimate matter and the thinking man. Descartes had tried to prove that the bodies of men and animals are machines actuated by springs like watches. Man, however, according to Descartes, possesses a soul wholly different in its properties from his body, and apparently incapable of being acted upon 
by it. Man only can think; animals are capable only of physical sensations, and have no consciousness. Into speculations like these we shall not venture, being content, like Locke, " to sit down in quiet ignorance of those things which upon examination are proved to be beyond the reach of our capacities." We shall merely note here and there facts ascertained by observation or experiment, and plain inferences drawn from such facts.

Swammerdam and Réaumur, besides many naturalists of less eminence, recorded a host of observations on the activities of insects. They contributed little to the discussion except new facts, for habit led them to ascribe without reflection every contrivance to the hand of Providence or else to Nature. Some of their facts, however, made a deep impression, none more than the exact agreement of the cells of the honeycomb with the form which calculation showed to be most advantageous. ${ }^{\mathrm{I}}$ The coincidence has lost some of its interest since the discovery that the theoretically best form of cell is hardly ever realised. ${ }^{2}$ Réaumur, ${ }^{3}$ in describing the process by which a certain leaf-eating caterpillar makes a case for itself out of the epidermis of an elm-leaf, showed that the caterpillar is not devoid of that kind of intelligence which adapts measures to circumstances. He cut off the margin where the upper epidermis of the leaf passes into the lower one, a margin which the insect had intended to convert into one side of its case ; the caterpillar sewed up the gap. He cut off a projection which was meant to form part of the triangular end of the case ; the caterpillar altered its plan, and made that the head-end which was originally intended to lodge the

I Réaumur, Hist. des Insectes, Vol. V., Mém. viii.

- Darwin, Origin of Species, chap. vii. $\quad{ }^{3}$ Vol. III., Mém. iv. 
tail. This observation anticipates a better-known example taken from the economy of the hive-bee by Pierre Huber, which is mentioned below.

Buffon $^{x}$ heard with impatience all expressions of admiration for the works of insects. His poor eyesight and his repugnance to minutiæ disinclined him to pay much attention to creatures so small, and he had set himself up as the rival of Réaumur in physics and natural history. To pour contempt upon insects gratified both feelings at once. Bees, he said, show no intelligence at all; their actions are purely automatic, and their much-vaunted architecture is merely the result of working in a crowd. The cells of the honeycomb are hexagonal, not by reason of forethought or contrivance, but because of mutual pressure ; soaked peas in a confined space form hexagonal surfaces wherever they touch.

The elder Huber seems to have denied to bees every trace of intelligence, but his son Pierre found it hard to go so far. ${ }^{2}$ He remarked that the storage-cells of a honeycomb are not always exactly alike; they may be lengthened, cut down, or curved, when requisite. Cells which had been rudely trimmed with a knife were repaired with such dexterity and concert as to suggest that even the hive-bee has "le droit de penser." Bees would under compulsion build upwards or sideways, instead of downwards, as they like to do. Finding that they sought to extend their combs in the direction of the nearest support, he covered the support with a sheet of glass, on which they could get no footing. They swerved at once from the straight line, and prolonged

"Hist. Nat., Vol. IV.

- The first edition of the Nouvelles Observations sur les Abeilles (1792) was the work of François Huber alone; the second (1814) was prepared by Pierre with the co-operation of his father, and is here credited to the son. 
their comb towards the nearest uncovered surface, though this obliged them to distort their cells. He was driven to the conclusion that bees possess "a little dose of judgment or reason." In our own time, when all conscious adaptation of means to ends is believed to be worthy of the name of reason, it requires no great courage to ask why we deny such an attribute to all the lower animals.

In spite of examples like this, the favourite expression "blind instinct" helped to strengthen the conviction that the mental processes of animals are unsearchable. It is impossible to deny that the epithet blind is appropriate in many cases. A bird will sit an addled egg all summer, or vainly but repeatedly attempt to make its tunnel in the insufficient breadth of a mud wall (Geositta). Of course such instances do not show that all the acts of the lower animals are devoid of intelligence.

Hume in I739 and again in I748 appealed to everyday observation of dogs, birds, and other animals of high grade. The facts seemed to him to show that animals as well as men are endowed with reason and able to draw inferences; he did not, however, credit them with the power of framing general statements, holding that experience operates on them, as on children and the generality of mankind, by "custom" alone. It is notorious that the dog and other higher animals learn by experience; Hume tells, for instance, how an old greyhound will leave the more fatiguing part of the chase to younger dogs, and place himself so as to meet the hare in her doubles. On the other hand (though Hume does not say so) man himself possesses noneducable instincts. In short, Hume sees no ground for drawing a line between the mental powers of man and those of the higher animals, though he attributes to 
man a power of demonstrative reasoning to which animals do not attain. In this he substantially agrees with Aristotle, ${ }^{\mathbf{T}}$ who maintained that in animals the germs of the psychical qualities of the man are evident, though, as in the child, they are undeveloped. Hume's teaching also accords with modern views; comparative anatomy, for instance, "is easily able to show that, physically, man is but the last term of a long series of forms, which lead by slow gradations from the highest mammal to the almost formless speck of living protoplasm, which lies on the shadowy boundary between animal and vegetable life." ${ }_{2}$

The detailed proofs which Hume was not enough of a naturalist to furnish were at length stated with admirable clearness and force by Leroy, whose Letters on Animals form the most important contribution made to the discussion during our period. Georges Leroy (1723-1789) was lieutenant des chasses under the last French kings, and had charge of the parks at Versailles and Marly. He wrote therefore with knowledge about the wolf, fox, deer, rabbit, and dog. His pages are enlivened by many touches of nature, interesting to readers who perhaps care little about psychology. Leroy attributes to the wolf observation, comparison, judgment. The wolf must mark the height of the fold which encloses a flock, and judge whether he can clear it with a sheep in his mouth. Wolf and she-wolf cooperate artfully in the running-down of prey. Sometimes the she-wolf will draw off the sheep-dog in pursuit, thus putting the flock at the mercy of her mate. Or one

'Hist. Animalium, VIII., i.

"Huxley's Hume, chap. v. Some few naturalists, who are entitled to respectful attention, such as Father Wasmann, author of The Psychology of Ants, do not even now receive the conclusions of Hume. 
of the two will chase the quarry till it is out of breath, when the other can take up the running on advantageous terms. An old fox shows knowledge of the properties of traps, and will rather make a new outlet or suffer long famine than encounter them. But when he finds a rabbit already caught, he realises that the trap has lost its power to hurt. Sheep-dogs can be educated to mind things which do not interest wild dogs, or dogs of other breeds; when, for instance, the flock is driven past a patch of wheat, the dog in charge will take care that the sheep do not damage the crop. A trained sporting-dog learns at length to trust his own judgment, even in opposition to that of his master, and sportsmen know that they must direct young dogs, but leave old ones to act for themselves.

From the middle of the eighteenth century to the present day naturalists and psychologists have been labouring to distinguish instinct from intelligence. It is not hard to define well-marked examples of each, and to show that a typical instinct is congenital (not the result of a process of education or self-education), adaptive (conducive to the welfare of the organism), co-ordinated by nerve-centres (thus excluding the superficially similar behaviour of the lowest animals and all plants), actuating the whole organism (thus excluding most, if not all, reflex acts in the higher animals, as well as the wonderful adjustments effected by bonecorpuscles and other parts of organisms), and common to all the members of a species or other group (thus excluding individual aptitudes). ${ }^{x}$ In the same way it is easy to point out clear differences between a bird and a tree. But just as a definition which shall separate

s Lloyd Morgan, Habit and Instinct, Introduction. 
every animal from every plant has hitherto been sought in vain, so it has hitherto been impossible to frame a definition which while including all instincts shall admit no case of reflex action or intelligence. The most ambiguous cases of all are perhaps to be found in insects, where, as will shortly be explained, our information is ill-fitted to support precise distinctions.

Many naturalists entertain some form of what may be called the us?-and-disuse or inherited-memory theory, supposing that the aptitudes of the offspring are influenced by the activities of the parent. Some cling to the belief that habits can be fixed and transmitted, and we must admit that the fixation and transmission of habits might explain a great deal. But all the evidence goes to prove that habits are not inherited at all, and that we must look elsewhere for the origin of instincts. Let naturalists who think differently try to account for the instincts of working bees or ants, which receive their psychical not less than their physical endowment from a long succession of ancestors, none of which worked for their living. Or let them try to explain the instances of spiders, insects, etc., which after egg-laying practise instinctive arts for the defence of their brood, standing over the eggs, carrying them about, blocking the entrance of the burrow, etc. May we not say that it is impossible for the acts of a parent to influence the congenital instincts of offspring which have already lost connection with the mother? But surely a theory of instinct breaks down which fails to account for the expedients by which the worker-bee, the worker-ant, and the spider provide for the safety of the unhatched brood or for the welfare of the community.

Darwin's Origin of Species threw a new light upon 
instinct by showing that natural selection can operate on the subtlest modifications. It can discriminate shades of hardiness to climate, shades of intellectual acuteness, or shades of courage. It can intensify qualities which appear only in adults past bearing or in individuals congenitally incapable of propagation. Human selection, though a blunt tool in comparison with natural selection, can originate a bold and hardy race of dogs, or showy double flowers incapable of producing seed. In the second case fertile single flowers continue the race, as in the garden Stock. Darwin pointed out that the barren double flowers of the Stock answer to the workers of social bees and ants, the fertile single flowers to the functional males and females. Every modification that works to the advantage or disadvantage of the race, whether we classify it as physical, intellectual, or moral, gives scope for the operation of natural selection.

The comparative psychology of small invertebrates, such as insects, is impeded by our imperfect knowledge of their nervous physiology. Introspection is here impossible; experimental physiology and pathology, which have done so much for the psycho'ogy of the higher vertebrates, almost impossible; analogy is a treacherous guide where the structures involved differ conspicuously. We have little to guide us in the psychology of insects except their behaviour, and that is often capable of a variety of interpretations. The only course is to adopt Pasteur's watchword, "Travaillons!"-the difficulties will diminish with time and labour.

\section{The Food of Green Plants.}

Common observation taught men in very early times that green plants draw nourishment from the soil, and 
that sunlight is necessary to their health. In the age of Galileo a Belgian physician and chemist, Van Helmont, endeavoured to pursue the subject by experiment. He planted the stem of a live willow in furnacedried earth, which was enclosed in an earthen vessel. Rain-water or distilled water was supplied when necessary, and dust excluded by a perforated lid. The loss of weight due to the falling-off of leaves was neglected. In the course of five years the tree was found to have increased to more than thirty times its original weight ; Van Helmont concluded that this increase was due to water only. Malpighi (167I), being guided mainly by his microscopic studies of the anatomy of the stem and leaf, taught that moisture absorbed by the roots ascends by the wood, becoming (apparently at the same time) aerated by the large, air-conducting vessels; that it enters the leaves, and is there elaborated by evaporation, the action of the sun's rays, and a process of fermentation; lastly, that the elaborated sap passes from the leaves in all directions towards the growing parts. It will be seen that this explanation, though incomplete, makes a fair approximation to the beliefs now held; for more than a hundred years after Malpighi's day less instructed opinions were commonly held. Hales ( 1727 ) recognised that green plants are largely nourished at the expense of the atmosphere; he dwelt also on the action of the leaves in drawing water from the soil, and in discharging superfluous moisture by evaporation.

Joseph Priestley, who had been proving that air is necessary both to combustion and respiration, made an experiment in $\mathrm{I} 77 \mathrm{I}$ to discover whether plants affected air in the same way that animals do. He put a sprig of mint into a vessel filled with air in which a candle had 
burned out, and after ten days found that a candle would now burn perfectly well in the same air. Air kept without a plant, in a glass vessel immersed in water, did not regain its power of supporting combustion. Balm, groundsel, and spinach were found to answer just as well as mint. Air vitiated by the respiration of mice was restored by green plants as readily as air which had been vitiated by combustion.

Priestley did not remark that the glass vessels employed in his experiments had been set in a window, and inattention to this point caused some of his attempts to repeat the experiment to fail. He was further perplexed by using vessels which had become coated with a film of "green matter," probably Euglæna. Such vessels restored vitiated air, though no leaves were present, and when placed in the sun, gave off considerable quantities of a gas, Priestley's "dephlogisticated air" (oxygen). Hardly any oxygen was given off when the green matter was screened by brown paper. Water impregnated with carbonic acid was found to favour the production of the green matter. To us, who have been taught at school something about the properties of green plant-tissues, it seems obvious that Priestley ought to have ascertained by microscopic examination whether his "green matter" was not a living plant. But he had always avoided the use of the microscope, his eyes being weak, and after some imperfect attempts in this way he made up his mind that the green matter was neither animal nor vegetable, but a thing suigeneris. Neglecting his most instructive experiments, and not waiting till he could devise new ones, or even disentangle his thoughts, he sent to the press a confused explanation, which seemed to teach that vitiated air may be restored by sunlight alone. 
A Dutch physician, named John Ingenhousz, who was then living in England, read Priestley's narrative and began to investigate on his own account. Without detailing his numerous experiments, we may give his own clear summary (condensed). "I observed," Ingenhousz says, "that plants have a faculty to correct bad air in a few hours; that this wonderful operation is due to the light of the sun; that it is more or less brisk according to the brightness of the light; that only the green parts of the plant can effect the change; that leaves pour out the greatest quantity of oxygen from their under surfaces; that the sun by itself has no power to change the composition of air." It will be seen that Priestley started the inquiry, devised and executed the most necessary experiments, and got excellent results. Then he lost his way, and bewildered by conflicting observations, which he was too impatient to reconcile, published a barren and misleading conclusion. Nothing was left for him but to acknowledge that Ingenhousz had cleared up all his perplexities.

Nicholas Theodore de Saussure, son of the Alpine explorer, showed in 1804 that when carbon is separated from the carbonic acid of the air by green plants, the elements of water are also assimilated, a result which owes its importance to the fact that starch is a combination of carbon with the elements of water. Saussure also proved that salts derived from the soil are essential ingredients of plant-food, and that green plants are unable to fix the free nitrogen of the air; all the nitrogen which they require is obtained from the ground.

We are unable to follow the history further. Though the main facts were established as early as the beginning of the nineteenth century, experimental results of 
scientific and practical interest have never ceased to accumulate down to the present time.

\section{The Metamorphoses of Plants.}

Speculations concerning the nature of the flower roused at one time an interest far beyond that felt in most botanical questions. The literary eminence ot Goethe, who took a leading part in the discussion, heightened the excitement, and to this day often prompts the inquiry: What does modern science think of the Metamorphoses of Plants?

Let us first briefly notice some anticipations of Goethe's famous essay. In the last years of the sixteenth century Cesalpini, taking a hint from Aristotle, tried to establish a relation between certain parts of the flower and the component layers of the stem. Linnæus worked out the same notion more elaborately, and with a confidence which sought little aid from evidence. His wonderful theory of Prolepsis (Anticipation) need not be described, far less discussed, here. He also borrowed and adapted an analogy which had been thrown out by Swammerdam. The bark of a tree, which according to the theory of Prolepsis gives rise to the calyx of the flower, he compared to the skin of a caterpillar, the expansion of the calyx to the casting of the skin, and the act of flowering to the metamorphosis by which the caterpillar is converted into a moth or butterfly. More rational than the speculations just cited, and more suggestive to the morphologists of the future, are his words: "Principium florum et foliorum idem est" (Flower and leaf have a common origin)-which was. not; however, a very novel remark in the eighteenth century. Long before Linnæus early botanists had remarked the resemblance of sepals, petals, and seed- 
leaves to foliage-leaves; Cesalpini has a common name for all (folium).

At the very time when Linnæus was occupied with his fanciful analogies, a young student of medicine named Caspar Friedrich Wolff, who was destined to become a biologist of great note, published a thesis which he called Theoria Generationis (Halle, I759). This thesis marks an epoch in the history of animal embryology, but what concerns us here is that Wolff examined the growing shoot, and there studied the development of leaf and flower. He found that in early stages foliage-leaves and floral-leaves may be much alike, and thought that he could trace both to a soft or even fluid substance, which is afterwards converted into a mass of cells. It seemed to him possible to resolve the flowering shoot into stem and leaves only. Wolff's thesis, or at least that part of it which dealt with the plant, was little read and soon forgotten; his studies of the development of animals were carried further and became famous.

Goethe in I790 revived Wolff's theory of the flower, without suspicion that he had been anticipated. It is only our ignorance, he said, when the fact came to his knowledge, that ever deludes us into believing that we have put forth an original view. As soon as he realised the true state of the case, he spared no pains to do Wolff full justice.

The aim of Goethe's Metamorphoses of Plants was to determine the Idea or theoretical conception of the plant, and also to trace the modifications which the Idea undergoes in nature. These two inquiries constituted what he called the Morphology of the plant, a useful, nay, indispensable term, which is still in daily use. He thought that he could discover in the endless variety of 
the organs of the flowering plant one structure repeated again and again, which gradually attained, as by the steps of a ladder, what he called the crowning purpose of nature-viz., the sexual propagation of the race. This fundamental structure was the leaf. The proposition that all the parts of the flower are modifications of the leaf he defended by three main arguments-viz., (I) the structural similarity of seed-leaves, foliageleaves, bracts, and floral organs ; $(2)$ the existence of transitions between leaves of different kinds; and (3) the occasional retrogression, as he called it, of specially modified parts to a more primitive condition. These lines of argument were illustrated by many wellchosen examples, the result of long and patient observation. Goethe did not, however, fortify his position by the likeness of developing floral organs to developing foliage-leaves, which had been Wolff's starting-point. $\mathrm{He}$ arrived independently at Wolff's opinion that the conversion of foliage-leaves into floral organs is due to diminished nutrition.

Linnæus's exposition of the nature of the flower had been read attentively by Goethe, who must have remarked that the conversion of organs to new uses was there described as a metamorphosis. That word had been, long before the time of Linnæus, appropriated to a particular kind of change-viz., an apparently sudden change occurring in the life-history of one and the same animal. It was therefore unlucky that Goethe should have been led by the example of Linnæus to employ the word in the general sense of adaptation to new purposes. He did not, however, expressly compare flower-production with the transformation of an insect, as Linnæus had done.

The reception of Goethe's Metamorphosen der Pflanzen 
was at first cold, but the doctrine which it enforced gradually won the attention of botanists, and by 1830 he was able to show that it had been accepted by many good judges.

Then came the discoveries of Hofmeister, followed by Darwin's Origin of Species. Naturalists soon ceased to put the old questions, and the old answers did not satisfy them. Wolff and Goethe had generalised the flowering plant until it became a series of leaf-bearing nodes alternating with internodes, but no such abstract conception could throw light upon the common ancestor of all the flowering plants, nor upon the stages by which the flowering plant has been evolved, and it was these which were now sought. Hofmeister brought to light a fundamental identity of structure in the reproductive organs of the flowering plants and the higher cryptogams. There has since been no doubt in what group of plants we must seek the ancestor of the flowering plant. It must have been a cryptogam, not far removed from the ferns, and furnished with sporophylls-i.e., leaf-like scales, on which probably two kinas of sporangia, lodging male and female spores respectively, were borne. The careful investigation of the fossil plants of the coal measures has brought us still nearer to the actual progenitor. Oliver and $\operatorname{Scott}^{\mathrm{I}}$ have pointed out that the carboniferous Lyginodendron, though showing unmistakable affinity with the ferns, bore true seeds, as a pine or a cycad does. Many other plants of the coal measures are known to have combined characteristics of ferns with those of cycads, while some of them, like Lyginodendron, crossed the frontier, and became, though not yet flowering plants, at least seed-bearers.

The discovery of a fossil plant which makes so near

s Phil. Trans., 1904. 
an approach to the cryptogamic ancestor of all the flowering plants may remind us how little likely it was that the ideal plant of Wolff and Goethe, consisting of leaves, stem, and other vegetative organs, but without true reproductive organs, should fully represent the type from which the flowering plants sprang. No plant so complex as a fern could maintain itself indefinitely without provision for the fertilisation of the ovum; the only known asexual plants are of low grade, and, it may be, insufficiently understood.

What substratum of plain truth underlies the doctrine of the metamorphoses of plants? Botanists would agree that all sporophylls, however modified, are homologous or answerable parts. Carpels and stamens are no doubt modified sporophylls. Petals are sometimes, perhaps always, modified stamens, and therefore modified sporophylls also. We must not call a sporophyll a leaf, for it contains a sporangium of independent origin, and the sporangium is the more essential of the two. The common origin of foliage-leaf, bract, perianth.leaf, sporophyll (apart from the sporangium), and seed-leaf is unshaken. We may picture to ourselves a plant clothed with nearly similar leaves, some of which either bear sporangia or else lodge sporangia in their axils. Part of such a primitive flowering plant might retain its vegetative function and become a leafy shoot, while another part, bearing crowded sporophylls, might yield male, female, or mixed cones. From an ancestor thus organised any flowering plant might be derived. But the chief wonder of the theory of Metamorphoses-viz., the derivation of stamen and pistil from mere foliageleaves-disappears. Anther and ovule take their real origin from the sporangium, whose supporting leaf is only an accessory. 
The chief steps by which the morphology of the flowering plant has been attained are these :-Cesalpini $\left(5^{8} 3\right)$, followed by several other early botanists, recognised the fundamental identity of foliage-leaf, perianthleaf, and seed-leaf. Linnæus (1759) added stamen and carpel to the list, identifications of greater interest, but only partially defensible. Wolff (I759) justified by similarity of development the recognition of floral organs as leaves. Goethe (r790) traced structural similarity, transitions, and retrogression in leaves of diverse function. Hofmeister (1849-57) showed a relationship between the flowering plant and the higher cryptogams. Oliver and Scott (1904), inheriting the results of Williamson's work, discovered a carboniferous seedbearing plant, one of a large group intermediate between ferns and cycads. It is now possible to explain the resemblance of the various leaf-like appendages of the flowering plant by derivation either from the leaves or the sporophylls (the latter not being wholly leaves) of some extinct cryptogam, which was either a fern or a near ally of the ferns.

\section{Early Notions about the Lower Plants.}

The fathers of botany neglected everything else in order to concentrate their attention upon the flowering plants, from which very nearly all useful vegetable products were derived. The lack of adequate microscopes rendered it almost impossible to investigate the structure and life-history of ferns, mosses, fungi, and algæ until the nineteenth century. As late as the time of Linnæus it was possible to maintain that they developed spontaneously, though the great naturalist himself called them Cryptogramia, thereby expressing his conviction that they reproduce their kind like other plants, but in 
a way so far not understood. Gaertner, a contemporary of Linnæus, pointed out one important respect in which the spores of cryptogams differ from the seeds of flowering plants, viz. that they contain no embryo.

Ferns.-Even before the age of Linnæus it was known that little ferns spring up around the old ones, and that a fine dust can be shaken from the brown patches on the back of ripe fern-leaves. The dust was reputed to be the seed of the fern, and in an age which believed in magic the invisibility of fern-seed made it easy to suppose that the possessor of fern-seed would become invisible also. When the microscope began to be applied to minute natural objects, the brown patches of the fernleaf were closely examined. William Cole of Bristol (1669), Malpighi, Grew, Swammerdam, Leeuwenhoek, and others, found the stalked capsules (sporangia), their elastic ring and the minute bodies (spores) lodged within them ; it seemed obvious to call the capsules ovaries and the spores seeds. Some time in the latter part of the seventeenth century Robert Morison, professor of botany at Oxford, who died in $168_{3}$, sowed spores of the harts-tongue fern, and next year got an abundant crop of prothalli, which he took to be the cotyledons. A little later, when it had been proved that flowering plants possess male and female organs, diligent search was made for the stamens and pistils of ferns and mosses, which of course could not be found, though identifications, sometimes based upon a real analogy, were continually announced. Late in the eighteenth century one John Lindsay, a surgeon in Jamaica, who was blest with leisure and a good microscope, repeated the experiment of Morison, which seems to have been almost foryotten. Having remarked that after the rains young ferns sprang up in shady places where the earth had been disturbed. 
it occurred to him to mix the fine brown dust from the back of a fern-leaf with mould, sow the mixture in a flower-pot, and watch daily to see what might come up. About the twelfth day small green protrusions were observed, which enlarged, sent down roots, and formed bilobed scales, out of which young ferns ultimately grew. In 1789 Sir Joseph Banks, who was reputed to be the best English botanist of the day, asked Lindsay's help. in sending West Indian ferns to Europe. Lindsay replied that it would be easier to send the seed, and that the seed would grow if properly planted. This was. new to Banks, who demanded further information. Lindsay then prepared a short illustrated paper, which Banks communicated to the newly formed Linnean Society. It will be seen that Lindsay was able to add nothing of much importance to what Morison had ascertained a century before. The spores were still identified with seeds, the prothallus was still a cotyledon, and for years to come botanists continued to seek anthers on fern-leaves. At this point we suspend for a time the history of the discovery (see below, p. 108).

Mosses.-Linnæus observed that the large moorland hair-moss (Polytrichum) is of two forms, only one of which bears capsules, and further that in dry weather the capsules emit masses of fine dust. No further progress was made until 1782 , when Hedwig, in a memoir of real merit, described the antheridium and archegonium of the moss, and traced the capsule to the archegonium. Interpreting the organs of the moss by those of the flowering plant, he called the antheridia anthers, the capsule was a seed-vessel, the spores were seeds, and the green filament emitted by the germinating spore a cotyledon. Such misinterpretations were then inevitable. 
Fungi.-Micheli in 1729 found the spores of several fungi, germinated them, and figured the product. The figures show the much-branched filament (mycelium) which burrows in the soil and constitutes the vegetative part of the fungus, and also here and there a pileus (mushroom, toadstool, \&c.), which is the fructification springing out of the mycelium. His account comprises the best part of what is known down to the present time of the reproduction of that group of fungi to which the mushroom belongs.

Algae.-Some early observers (Réaumur among the rest) studied the enlarged and fleshy branches of brown seaweeds, and discovered the seed-like spores.

This scanty knowledge of the life-history of cryptogams sufficed until the nineteenth century, when the study was resumed with better microscopes and in a far more connected way, with results of the highest interest and importance (see below, p. ro8). 


\section{PERIOD IV.}

$$
\text { I } 790-185^{8}
$$

\section{Characteristies of the Period.}

THE first French republic and the first French empire were associated with a great outburst of scientific energy. French mathematics, astronomy, and physics were pre-eminent. England suffered from isolation during the continental war, but Davy, Young, the Herschels, Watt (now past his prime), Dalton, and William Smith supported the scientific reputation of their country. In Germany this was the age of Goethe and Schiller; Alexander von Humboldt was prominent among the scientific men of Prussia. The forty years' peace, during which reaction prevailed in many parts of Europe, was in England and America a time of steady growth and progress.

\section{Sprengel and the Fertilisation of Flowers.}

Conrad Sprengel, an unsuccessful schoolmaster who lived in a Berlin attic and got his bread by teaching languages or whatever else his pupils wished to learn, wrote a book which marks an epoch in the study of adaptations. This was his Secret of Nature Discovered, which appeared in I793. Half a century passed before its merit was recognised by any influential naturalist; even then the recognition was private, and never reached the author, who had died long before. There was no striking of medals, no jubilee-celebration, 
nothing more than this, that Robert Brown recommended the book to Charles Darwin, who found in it, as he says, "an immense body of truth."

In 1787 Sprengel had remarked that the bases of the petals of Geranium silvaticum are beset with long hairs. Persuaded that no natural structure can be devoid of meaning, Sprengel asked what purpose these hairs might serve. A honey-gland in their midst suggested that they might protect the honey by keeping off the rain, which easily enters this shallow flower. Other honeysecreting flowers were found to possess mechanisms adapted to the same end. His first question suggested a second: Why should flowers secrete honey?

Malpighi had described the honey-glands of crownimperial ( 1672$)$, and had seen that the honey must be secreted by the petals, and not deposited from the atmosphere, according to the notion then current. Kölreuter (I76I) had showed that insects may effect the pollination of flowers. Linnæus ( 1762 ) had given the name of nectary to the honey-gland. He thought that the honey served to moisten the ovary, though he knew of staminate flowers furnished with nectaries. $\mathrm{He}$ also threw out the alternative conjecture that the honey is food for insects, which disperse the pollen by their wings. Sprengel improved upon all his predecessors, and made it clear that transference of pollen is the main purpose of the honey in flowers. He was put on the right track by the study of a forget-me-not flower. Here he found the honey protected from rain by the narrowness of the corolla-tube, whose entrance was almost closed by internal protuberances. The protuberances were distinguished by their yellow colour from the sky-blue corolla, and this conspicuous colouration led Sprengel to infer that insects might be thereby 
induced to seek for the store of honey within. He tested his conjecture by examining other honey-bearing flowers, and soon collected many instances of spots, lines, folds, and ridges, which might not only make insects aware of hidden stores of honey, but guide them to the exact place. Contrivances of the most diverse kinds, but all tending to invite the visits of insects and utilise them for the benefit of the plant, rewarded Sprengel's continued inquiries. He found that nightflowering plants, which could derive no advantage from coloured patterns, often have large white corollas, easily discerned in a faint light, and that these flowers give out an odour attractive to nocturnal insects. $\mathrm{He}$ found that the pollen-masses of an orchis are actually removed by large insects, though here no honey could be detected in the flower. Sprengel's fertility in probable conjecture is shown by his explanation of this puzzling case; he suggested that the orchis is a sham honey-bearer (Scheinsaftblume), which attracts insects by assuming the conspicuous size and coloration found in most honied flowers. Darwin suspected, and Herman Müller proved, that though the spur of the orchis-flower is empty, it yields when pierced a fluid attractive to bees and other insects. Sprengel discovered too how insects get imprisoned in the corolla of an Aristolochia, whose reflexed hairs allow small flies to creep in, but effectually prevent their escape until they have fertilised the pistils, when the hairs relax. These are only specimens of a multitude of adaptations which fill the book.

Sprengel insists upon the study of flowers under natural conditions; he could never have made out by the examination of plucked flowers how Nigella is fertilised. Flies with attached pollen-masses, which he 
found in spiders' nests, gave him the hint as to the way in which the fertilisation of orchids is effected. Definite questions must be put if observation is to be profitable. What is the use of honey to the plant-of this coloured spot-of these hairs? He notes the peculiarities of wind-fertilised and insect-fertilised flowers, the relative abundance of the pollen, the form of the stigma, the presence or absence of honey, the size, colour, and scent of the corolla. Here is a pretty illustration from his pages. Pluck a branch of hazel, aspen, or alder, with unexpanded catkins, and also one from the male sallow; place them in water, and keep them in a sunny window until the anthers are ripe. A vigorous puff will then discharge a cloud of pollen from the rwindfertilised catkins, but none from the insect-fertilised catkin of the sallow. What Linnæus said about the flowers of trees appearing before the leaves, in order that the pollen may more easily reach the stigmas, holds good, Sprengel remarks, only of wind-fertilised trees. The lime, which is insect-fertilised, flowers in the height of summer, when all the branches are crowded with leaves.

Sprengel left it to later biologists to complete his discovery. "That wonderfully accurate observer, Sprengel," says Darwin, " "who first showed how important a part insects play in the fertilisation of flowers, called his book The Secret of Nature Displayed; yet he only occasionally saw that the object for which so many curious and beautiful adaptations have been acquired, was the cross-fertilisation of distinct plants; and he knew nothing of the benefits which the offspring thus receive in growth, vigour, and fertility." Not even

- Cross and Self-Fertilisation of Plants, chap. xi. 
Darwin could exhaust the inquiry. "The veil of secrecy," he goes on, "is as yet far from lifted."

\section{Cuvier and the Rise of Palæontology.}

If this historical sketch had been prepared within a few years of the death of Cuvier, it would no doubt have held him up as the greatest of zoologists and comparative anatomists. Nor would it have been hard to find reasons for such a verdict. His Règne Animal extended and corrected the zoological system of Linnæus; his comparative anatomy, and especially his comparative osteology, were far ampler and more exact than anything that had been attempted before. It would not have been forgotten, moreover, that he was the practical founder of the new science of palæontology.

At a later time, say in the sixties and seventies of the nineteenth century, when the Origin of Species controversy was in full blast, any estimate of Cuvier by an evolutionist would have been much less laudatory. Cuvier had actively opposed that form of evolution which had been brought forward in his day, and with such power as to close the discussion for a time. The assailants of the Origin of Species found his refutation of unity of type and progressive development adaptable to the new situation, and the reasoning which had pulverised Geoffroy St. Hilaire was brought out again in order to pulverise Darwin. Then the supporters of Darwin found it necessary to show that Cuvier was by no means infallible. This they were able to do without introducing matter foreign to the main question, for Cuvier's exposition of fixity of species, of the principles of classification and of the process of extinction, were entirely opposed to the beliefs not only of Darwin, but 
of Lyell and the whole school which stood out for historical continuity, treated history of every kind as a process of development, extended almost without limit the duration of life on the earth, and enforced the obvious but neglected truth that results of any magnitude whatever may proceed from small causes operating through a sufficient length of time.

Darwin's main contentions are now accepted by the scientific world, and Cuvier's hostility to particular forms of evolution has become a mere historical episode of no lasting importance. Angry disputes concerning the weight of his authority are at an end ; he is not to be blamed because thirty years after his death he was set up as judge of a cause which he had not heard. We are now ready to make fair allowance for the time in which his lot was cast - an age when geology, embryology, palæontology, and distribution were mere infants, some of them hardly yet born. We can also admit without reserve the incompetence of certain of Cuvier's antagonists, and justify the severity with which he treated unity of type as stated and defended by Geoffroy St. Hilaire. Now that the dust of controversy has settled, we are chiefly concerned to inquire : What of all Cuvier's work has proved to be really permanent? His zoology and his comparative anatomy have had to be completely re-cast, partly because of the new light thrown on them by embryology and the doctrine of descent with modification. His studies of extinct vertebrates, however, called into existence a new science, the science of Palæontology, ${ }^{\mathrm{x}}$ and it is mainly

- Cuvier did not himself use the word palcontology, which first came in about $1 S_{3}$. In the same way Buffon writes on the history of animals, not on $z o n \log r y$, and on the theory of the earth, not on geolog $y$. 
this which gives him a lasting and honoured place in the history of biology.

At the end of the eighteenth century it had been rather grudgingly admitted that some few animals were actually extinct. Buffon was able to quote as indubitable examples the mammoth and the mastodon. Their occurrence in countries unknown to the ancients, such as Siberia and North America, disposed of the explanation long clung to by the learned-viz., that their bones were the remains of elephants which had been led about by the Roman armies, while their large size and the ease with which they can be recognised rendered it highly improbable that they still survived anywhere on the surface of the globe.

It was therefore natural that Cuvier's first study in palæontology should relate to extinct elephants. $\mathrm{He}$ compared and distinguished several species, showed that they were distinct from the existing Asiatic and African species, a fact which had escaped the notice of Pallas, and argued from the well-known case of a Siberian mammoth preserved in ice and frozen mud with hardly any decomposition that it must have been overwhelmed by a sudden "revolution of the earth." Whatever we may think of Cuvier's geology, his comparisons of all known elephants, recent and fossil, introduced a new standard of exactness into these inquiries. From this beginning he went on to study all the extinct vertebrates which he could discover in public or private collections. By $182 \mathrm{I}$ he had published elaborate and well-illustrated descriptions of near a hundred extinct animals, an extraordinary output for one investigator.

The most remarkable of his palæontological discoveries were made at home, in the lower tertiary rocks which underlie the city of Paris. He proved that in 
the valley of the Seine a large population of animals, all now extinct, had formerly flourished. None of these discoveries impressed his contemporaries more than the celebrated case of the fossil opossum. The bones were imbedded in a slab of gypsum, and were at first imperfectly exposed. The lower jaw, however, exhibited a peculiarity of marsupial or pouched animals, for its angle had an inwardly projecting shelf, not found in other quadrupeds. The opossums, like all marsupial animals, bear on the front of the pelvis two long bones, which support the pouch. These were as yet concealed, and Cuvier delayed clearing them until he had summoned friends, some of whom may have been sceptical about the possibility of reasoning with certainty from anatomical data. Warning them what to expect, he removed with a sharp tool the film of stone, and revealed the long and slender marsupial bones. ${ }^{x}$ The ancient existence of marsupials in France was then a striking and almost incredible fact ; increase of knowledge has not lessened its interest, though it has abated some of the wonder.

The fossil ungulates (hoofed quadrupeds) of the Paris basin taxed Cuvier's patience and skill to the utmost. In the tiresome work of piecing together a multitude of imperfect skeletons he set an example to all future palæontologists. That he drew general conclusions which we are unable to accept, and failed to draw conclusions which seem obvious to us, will surprise nobody whose reading has taught him how unprepared were the biologists of that age to handle great questions concerning the origin and extinction of races. Cuvier recognised among the fossils of the Paris quarries the form.

I This anecdote has also been related in a rather different 
bones of tivo genera of ungulates very different from any of recent times. One resembled the rhinoceros, tapir, and horse in being odd-toed; this he called Palæotherium. Another had the hind-foot even-toed, like a ruminant, though the fore-foot, with which he was imperfectly acquainted, showed points of resemblance to the other group. How cautiously he did his work may be gathered from the fact that he spent fifteen years upon the collection of facts before he attempted to restore these extinct forms, though almost every bone in their bodies had during that time passed through his hands.

The great interest of these fossil ungulates to the modern biologist is that they are relatively primitive types of the order. Palæotherium is not far from the ideal common ancestor of the rhinoceros, tapir, and horse; Anoplotherium not altogether unlike the ideal common ancestor of the hippopotamus, the swine, and the ruminants. It has been suspected that Cuvier was less obstinately devoted to the tenet of fixity of species than he was willing to admit in public. Whatever his private leanings may have been, he stood out resolutely for cogent proofs of transmutation. When it was contended that the Palæothere might have been the remote ancestor of existing ungulates, he demanded that the intermediate links should be produced. His demand could not be met till many years later, though intermediate forms between the Palæothere and the horse have since been furnished in abundance. Reserve about far-reaching deductions was surely wise at a time when plausible speculation was rife, and we ought not to judge Cuvier severely for having aspired to a rigour unattainable in a natural science, and certainly not always observed by himself. He hoped to see biology become 
as exact as astronomy. The hope may have been chimerical, but emphasis on this side was not altogether out of place in the generation of Geoffroy St. Hilaire and Oken.

If the great master who laid the foundations of palæontology could revisit the scene of his former labours, he would find that many strange things had happened since the appearance of his Ossemens Fossiles. He would perhaps be stupefied at first to discover how little is now made of the Revolutions of the Earth, the proofs of which had seemed to him unimpeachable, while the conjectures about the development of new races, which in his own day had been almost negligible, have proved to be anticipatory of fundamental biological truths. The first shock over, one can imagine the zest with which he would strive to combine the familiar facts into a body of new doctrine. The ungulates, recent and fossil, would of course interest him particularly. $\mathrm{He}$ would recognise the gradations of structure which run through the whole order, branching and crossing in all directions; gradation in the number of the toes, in the rearing of the body more and more upon the toe-tips, in the progressive complication of the teeth. One chain of examples would lead from the shallow, tuberculate molar of the pig to the molar of the horse or ruminant, deep and massive, with crescentic enamelfolds ; another would illustrate the gradual development of tusks from ordinary incisors or canines; a third series would show the steps by which the primitive ungulate dentition became reduced to the dentition of the elephant, with only a single pair of incisors, enlarged into tusks several feet long, with no canines but molars of great weight, complicated by extreme folding. It would surprise and delight him to compare the almost 


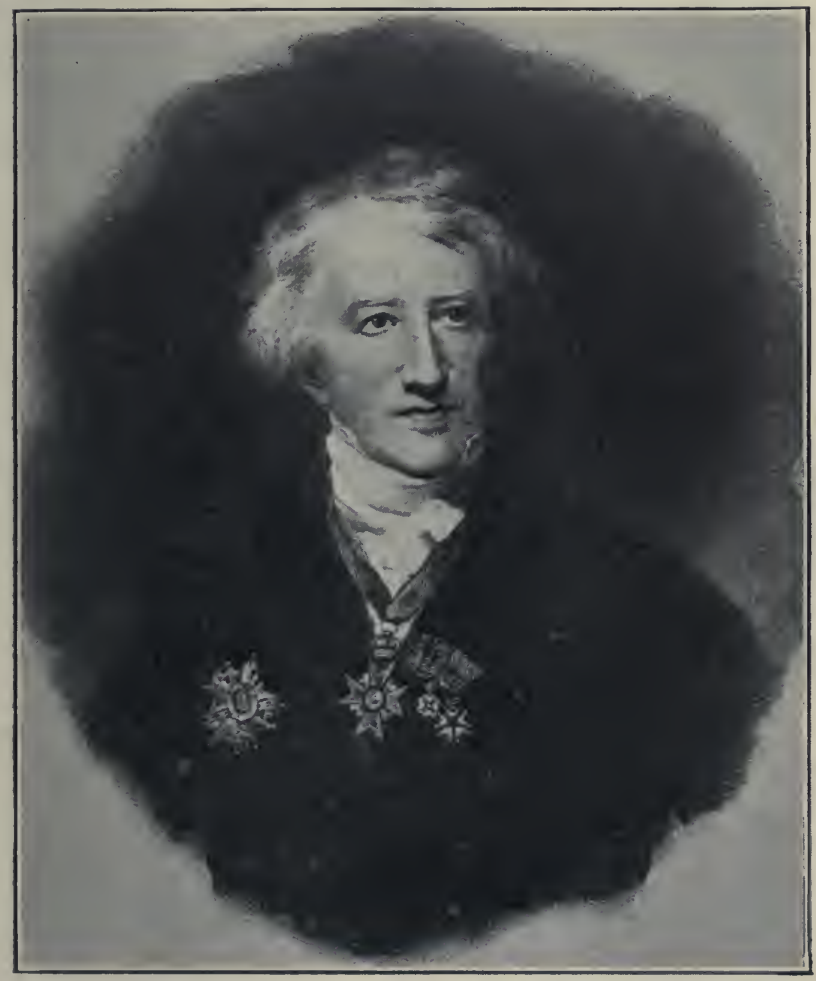

Georges Cuvier.

From an engraved copy of the purtrait by Pickersgill. 
insensible steps by which his own Palæothere can be seen to pass into the modern horse. Then we can imagine how our regenerate Cuvier would draw nearer and nearer to the common ancestor of the whole group, a five-toed, plantigrade ungulate, with the full dentition of forty-four unspecialised teeth, and how readily he would admit that Phenacodus, both in its structure and its geological horizon, was just the common ancestor that theory required. The proofs of intermediate stages between ancient and modern ungulates which he had once called for in vain, he would now find ready to his hand. It might weil seem that the history of the ungulates, with all its modern expansions, would suffice to occupy even his unparalleled energy. He would see with delight how the palæontology which he had been the first to treat as a science has enlarged the comparative anatomy of which also he was so great a master. $\mathrm{He}$ would cheerfully admit that both yield proofs of that doctrine of descent with modification which a hundred years ago seemed to him so questionable.

\section{Chamisso on the Alternation of Generations in Salpa.}

Trembley (see p. 57) had shown that Hydra, though an animal, multiplies by budding like a plant. He got indications, upon which he did not altogether rely, that it also propagated by eggs, and ten years later ( $\mathrm{I} 754$ ) this supposition was confirmed by Roesel, who figured the egg, though he was unable to demonstrate that a young Hydra issues from it; subsequent inquiry has placed the fact beyond doubt. In 1819 Chamisso announced that Salpa, a well-known Tunicate which abounds at the surface of the sea, exhibits a regular alternation of the two modes of increase, the egg-producing form being succeeded by a budding form, the 
budding form by the egg-producing form, and so on indefinitely. Sars a few years later showed that the common jelly-fish Aurelia also propagrates by eggs and buds alternately. Here the familiar swimming disks, which are of two sexes, produce eggs from which locomotive larva issue. The larva at length settles down and takes a Hydra-like form. It pushes upwards an ascending column, which divides transversely and forms a pile of slices, each destined to become a free, sexual Aurelia. The alternation of generations may be regarded as resulting from the introduction of budding into the early stage of a life-history which culminates in sexual reproduction, much as if a caterpillar were to divide repeatedly and form more caterpillars, each of which ultimately became a moth. The case which has been given as an illustration actually occurs in nature. A parasitic caterpillar, that of Encyrtus, divides while still an embryo, so that one egg produces several moths. ${ }^{x}$ Many other cases of alternation have since been found among animals, and it seems to be the rule among plants.

Alternation of generations may be complicated by association with transformation, by the omission of stages usual in the class, and by budding-out from one part instead of from the whole body. In particular cases the complication becomes so great that biological language breaks down under it. Such terms as generation, individual, organ, larva, adult, cannot always be used consistently without either being strained or artificially limited.

"The same process of "embryonic fission" occurs in other animals also. one of which is a mammal (Praopus). 


\section{Baer and the Development of Animals.}

The curiosity of the ancient Greeks led them to look for the chick within the egg, and Aristotle mentions the beating of the heart as a thing which might be observed in a third-day embryo. After the revival of science Fabricius of Acquapendente figured the chief stages of development, from the first visible rudiments to the escape from the egg-shell. Harvey, the discoverer of the circulation, not only studied the developing chick, but took advantage of the rare opportunity of dissecting breeding does from the royal parks. His treatise on Generation is unfortunately impaired by Aristotelian philosophy, and some of the theories there set forth gave much trouble to Swammerdam. The oft-cited maxim "Omne vivum ex ovo" does not occur exactly in this form in Harvey's writings, ${ }^{\mathrm{I}}$ nor does it fairly state his own belief. Those who read his De Generatione will see that his knowledge was insufficient to justify so wide a generalisation; on this head it is enough to mention that he was persuaded of the production of insects without parents from putrefying matter. ${ }^{2}$

Malpighi was the first to apply the microscope to the embryonic chick. His figures are surprisingly full

" Linnæus (Fund. Bot. § I34, and Sponsalia Plantarum) gives it as above; Harvey has "Ex ovo omnia "; "ovum esse primordium commune omnibus animalibus," etc.

${ }^{2}$ Harvey need not have gone outside the writings of Aristotle to get the substance of his generalisation. He would have found there that the chief task of both plants and animals is propagation, either by seeds, or eggs, which Aristotle believed to be equivalent to seeds (Hist. anim., VIII., i.; De anim. gen., I., iv.; I., xxiii.). Aristotle excepted the "imperfect animals," such as insects, and the seedless plants, concerning both of which his knowledge was misty and inaccurate; there is no indication that Harvey was better informed. 
of interesting detail, and so far in advance of their age that they long failed to produce their due effect. On one point Malpighi unconsciously led naturalists astray for a hundred years or more. On examining a fowl's egg which he supposed to be unincubated, he discovered within it an early embryo. From this he concluded that the embryo pre-exists in the egg, like a plantembryo in a seed. He mentions one circumstance which makes everything intelligible. The egg was examined in August, during a time of great heat, and the Italian summer no doubt started development, like the hot sand of Aden, in which Chinamen hatch their eggs. Swammerdam too enforced the same belief in pre-existing germs. From the fact that the butterfly can be revealed by opening the skin of a full-fed caterpillar he inferred (quite contrary to the opinion which he expresses elsewhere) that one animal had formed inside another. This led him to say that there is no such thing as generation in nature, but merely the expansion of germs which lie enclosed one within another. By his theory he explained how Levi could pay tribute to Melchizedek before he was born, and how the sin of Adam can be laid to the charge of all his posterity. The belief in the pre-existence of germs was first shaken by Caspar Wolff (see p. 8I), who examined unincubated eggs but found no germ which could be detected by the histological methods then employed.

Swammerdam's Biblia Natura contains useful figures of early and late tadpoles; in particular, he describes a stage in which the body is entirely composed of rounded "lumps" or "granules," the cells of modern biology.

Early in the nineteenth century Pander and Baer, both of whom were pupils of Döllinger, a teacher of 
extraordinary influence, gave a new impetus to the study of development. Pander (1817-8) published an account of the early stages of the chick, illustrated by beautiful plates by D'Alton. Baer (1828-37) carried the work much further, not only greatly extending the knowledge of the developing chick, but discovering the mammalian ovum (1827), and announcing generalisations which down to 1859 were the most luminous that embryology had ever furnished; we may call him the founder of comparative embryology. He shows that development may supply decisive indications of the zoological position of animals ; it teaches, for instance, that insects are of higher grade than arachnids or crustaceans, and that amphibians ought not to be united with reptiles. He describes the development of an animal as a process of differentiation, the general becoming special, and the homogeneous heterogeneous; differentiation is, he remarks, the law under which not only animals but solar systems develop. He maintains that the embryo, though gradually attaining complexity, makes no transition to a different type-e.g., the vertebrate is never in any stage anything but a vertebrate. All animals, he believes, are probably at first similar, and take the form of a hollow sphere (the gastrcea of modern embryology). There are, he says, no new formations in nature; all is conversion. When he comes to speak of the pharyngeal clefts of mammals and birds, recently discovered by Rathke, he remarks that their correspondence with the gill-clefts of fishes is obvious. We wonder what is coming next, but our curiosity is not gratified by any memorable deduction. Neither here nor in his miscellanies (Reden), published nearly fifty years later, does he admit that mammals and birds can have descended from gill-breathing 
vertebrates. If we are inclined to hint that Baer, having gone so far, might well have gone a little farther, it is only fair to recollect that every leader in science is more or less open to the same reproach.

\section{The Cell Theory.}

Any one of the higher animals or plants admits of analysis into organs, each adapted to one or more functions. Bichât (180I) showed that the body of one of the higher animals is not only a collection of organs, but also a collection of tissues, and the same is true of the higher plants. Analysis of the organism was carried a step further when in $183^{8}-9$ Schleiden and Schwann announced that all the higher animals and plants are made up of cells, which were at first supposed to consist in every case of a cell-wall, fluid contents, and a nucleus. ${ }^{x}$ It was soon discovered that the cell-wall is as often absent as present, and that the cell-contents are not simply fluid; the nucleus is still believed to be universal. Schwann proved that nails, feathers, and tooth-enamel, though not obviously cellular, consist of nothing but cells, and it was afterwards shown that bone, cartilage, fatty tissue, and fibrous tissue arise by the activity of cells which disappear from view in the abundance of their formed products. The individual cells of a complex organism are usually themselves alive ; sometimes, as in ciliated epithelium, they give indications of life

- Hooke figured a thin section of dry cork in his Micrographic (1665), remarking that it was divided into "little boxes or cells." The word cell was suggested by the resemblance of the tissue to a honeycomb; since $183^{8}$ it has been thoughtlessly extended from the skeleton to the particle of living matter enclosed within it. Robert Brown (1831) showed that a nucleus is usual in plant-cells; it had been figured by Fontana and others long before. Down to $183^{8}$ no results of biological interest followed from the discovery. 
long after they have been separated from the body. The preponderating importance of the transparent jelly or protoplasm became clear when it was recognised that this alone is invariably present, and that this alone responds to stimuli. The nucleus is believed to be only a specialised part of the cell-protoplasm.

The cell-theory, like nearly every theory, was neither altogether new nor in its first form altogether complete. Before $183_{3} 8$ cell-division, as we should now call it, had been indistinctly seen to be the process by which the body of one of the higher animals is built up. Leeuwenhoek and Swammerdam had found a wholly cellular stage in frog-embryos (see p. 103), while Prévost and Dumas in 1824 had in effect discovered that the cells of which such embryos consist result from repeated division of an egg; - Mohl in 1835 observed the actual division. Even Schwann, however, was not acquainted with the important fact that every cell arises by the division of a pre-existing cell.

Swarm-spores of algæ showed that protoplasm, when unenclosed in a cell-wall, can move about, direct its course, and change its shape. Knowledge of this fact did more than rectify the definition of the cell ; it effaced one distinction between plants and animals, and gave a hint of the resemblance of primitive cells to such simple organisms as Amœba.

Martin Barry in 1843 announced that certain Protozoa (that name was not yet in use) are simple cells. He pointed out that they possess nuclei, like those of tissuecells, and compared their increase by fission with the cleavage of the egg. Single cells were thus shown to be not only capable of locomotion, which was already known, but able to provide for their own support. The Protozoa and Protophyta (i.e., the simplest animals and 
plants, which are not always to be clearly separated) are now known to be autonomous cells, increasing by fission, and often forming colonies. Conjugation (fusion of similar individuals) often precedes fission, and when it was proved $(186 \mathrm{I}-5)$ that ova and spermatozoa are true cells, it was seen that fertilisation, as we know it in the higher animals, is only a special form of the conjugation observed among the. Protozoa. To the Protozoa it is now possible to trace, without any startling break of continuity, all the multicellular organisms, their tissues, the growth of those tissues by repeated fission, their eggs, and the process of fertilisation which precedes cleavage. The old Greek riddle, "Which came first, the fowl or the egg?" may now receive the answer: "Neither; their common starting-point is to be found in the Protozoa, which, even when adult, represent the primitive unicellular condition, to which all the higher animals revert once in every generation."

It is not without reason that biologists dwell on the unifying influence of the cell-theory, which has become a chief support of that still wider unifying influence, the Origin of Species by Natural Selection. When it was discovered that all living things, whether plants or animals, consist of nucleated cells which increase by fission, and that in all of them cell-fission is started anew from time to time by a cell-fusion, it was strongly suggested that resemblances so striking and so universal can only proceed from a common descent.

During the last half-century the study of cells has led to a great increase of knowledge respecting all bodily functions, whether in health or disease. We now look to it as perhaps the most hopeful source of new light upon the important question of hereditary transmission. 


\section{The Seientifie Investigation of the Higher Cryptogams.}

We now resume the history of a study which down to the end of the eighteenth century had yielded only meagre and uncertain results (see above, pp. 85-88). At the date in question it had been ascertained that the spores (then called "seeds") of ferns, and probably of other cryptogams, are capable of propagating the species, but no one knew precisely what part the spore played in the life-history, or could explain the true difference between a cryptogam and a flowering plant. The great improvements in the construction of the compound microscope which were effected between 1812 and 1830 rendered it possible to elucidate much more thoroughly the structure and development of the chief groups of cryptogams. The sexual reproduction of algæ was explored; moving filaments (spermatozoids) were seen to enter the chambers in which embryos afterwards formed; the conjugation of similar cells was observed in algæ and fungi, and recognised as a simple mode of sexual reproduction. The resemblance of the spermatozoids of mosses and ferns to animal spermatozoa was noted, and their participation in the process of fertilisation was more and more closely followed until at length Hofmeister in $185 \mathrm{I}$ saw them fuse with the egg-cell of a fern. Suminski, whose full name, Lesczyc-Suminski, is unpronounceable by Englishmen, had discovered (in 1848 ) that the prothallus of a fern, which is the product of the germinated spore and had been hitherto taken for the cotyledon, bears two kinds of reproductive organs, one of which liberates spermatozoids, while an egg-cell is developed within the other. He did not correctly describe all the details, but he showed where the essential reproductive organs 
form, and where fertilisation is effected. The masterly researches of Hofmeister (1849-57) fused what had been a number of partial discoveries into a connected and luminous doctrine. He proved that the prothallus is one of two generations in the life-history; that it begins with a spore and ends with a fertilised egg-cell; that in the higher cryptogams there is a regular alternation of generations; that the prothallus of the fern answers to the leafy moss, while the leafy fern is the equivalent of the moss-capsule ; that the egg-cell is the same structure in both cryptogams and flowering plants; that the pollen-tube and the seed are found to-day only in flowering plants; that the gymnosperms make a transition from the higher cryptogams to the angiosperms ; that unity of plan pervades the whole series of mosses, ferns, fern-like plants, gymnosperms, and angiosperms. Before Darwin's Origin of Species had appeared Hofmeister presented to evolutionists a ciear example of a descent in which every principal term is well authenticated, while the extremes are far apart.

\section{The Enrichment of English Gardens.}

If some unreasonably patriotic Englishman should be seized with the whim of keeping none but truly British plants in his garden, he might enjoy the shade of the fir, yew, oak, ash, wych-elm, beech, aspenpoplar, hazel, rowan-tree, and the small willows, but he would have to forego the common elm, the larger poplars and willows, the larches, spruces, and cypresses, the rhododendrons, and all the shrubs popularly called laurels. Of fruits he might have the crab-apple, sloe, wild cherry, gooseberry, currants (black and red), the raspberry, strawberry, and blackberry, but none of the improved apples, pears, or plums, and no quinces, 
peaches, or apricots. His vegetable garden might yield cabbages, turnips, carrots, and celery (all deficient in size, flavour, and variety), but no cauliflowers, Brussels sprouts, parsley, lettuces, peas, beans, leeks, onions, or spinach. The handsomest of his flowers would be dog-roses, mallows, and primroses.

Before Europe was sufficiently enlightened to care about exact records valuable foreign plants had already been introduced. Vines, apples, pears, cherries, and plums, besides improved vegetables, such as the cauliflower, bean, garden-pea, and cucumber, had been brought from temperate Asia or Egypt. Wheat and barley, neither of them native to Europe, had to some extent replaced rye and oats, which may have existed naturally in those European countries which border on Asia. Britain, while yet a Roman province, shared in these benefits, and it is believed that the common elm, besides certain fruit-trees and pot-herbs, have been continuously grown in our island through all the troubled ages which separate us from the RomanoBritish times. Leek, garlic, and onion are ancient acquisitions. To our Old-English forefathers garlic was the spear-leek, distinguished by its long, narrow leaf from the broad-leaved common leek, just as a garfish was distinguished from other fishes by its long body and pointed head; onion was the enne- or ynneleek (onion-leek); the most important of the three was probably that which retained the root-word without prefix-the leek proper.

During many centuries, when the rights of small proprietors were little respected and knowledge was scanty, the religious houses were distinguished by the diligence with which they tended their gardens. Flowers, fruits, and simples were cultivated, and plants 
were now and then imported from foreign monasteries. The English names of the plants, which are often adaptations of Latin words, still testify to the care of gardeners who were in the habit of using Latin.

Much improvement was not to be expected so long as England suffered from frequent and desolating wars within her own borders. When these at last subsided, great English gardens, such as those of Nonsuch, Hatfield, Theobalds, and Hampton Court, began to parade their beauty; strange trees, shrubs, and flowers were brought from the continent, and as early as Queen Elizabeth's time our shrubberies and walks were admired by spectators familiar with the best that Italy and France could show. The new horticulture was, however, long an exotic among us, and John Evelyn, whose Sylva appeared in 1664, was "the first to teach gardening to speak proper English."

In the latter part of the sixteenth century the following new plants among others were brought from central or southern Europe: The poppy and star anemones, the hepatica, the common garden larkspur, the winter aconite, the sweet-William, the laburnum, Rosa centifolia (of eastern origin, the parent of countless varieties and hybrids), the myrtle, the lavender, the cyclamen, the auricula, Iris germanica, and many other Irids, the oriental hyacinth, several species of Narcissus, the white and Martagon lilies, and the absurdly named dog's-tooth-violet (really a lily). The botanist Clusius introduced the jonquil and the Tazetta narcissus from Spain to the Low Countries. The Judas-tree (i.e., tree of Judxa) was brought from the Mediterranean, where the hollows of the hills are filled in April with its pale-purple blooms. The white jasmine was imported from Asia, and the castor-oil plant from Africa. 
The great accessions of geographical knowledge made during the fifteenth and sixteenth centuries were slow to affect horticulture. Ships were then few and small, and the passage from Hispaniola or Calicut to Cadiz or Lisbon occupied weeks or even months. Moreover, the conquests of Spain and Portugal (Goa, the Moluccas, Brazil, the West Indies, Peru, and Mexico) lay mostly within the tropics, and could furnish hardly any plants capable of enduring a European winter. Special pains were, however, taken to bring over some valuable food-plants which were thought likely to thrive in Europe. Before any European landed in America the potato had been cultivated by the Indians of Peru, a country which, though lying almost under the line, rises into cool mountain-districts. Potato-tubers were soon introduced to Spain and Italy, and a little later to other parts of Europe ; Raleigh's planting of potatoes on his estate near Cork came a few years later. The edible tomato, which is distinguished from the wild form by its enlarged fruits, was apparently cultivated in Peru before the first landing of the Spaniards. The unusually high proportion of edible plants among the first importations from America and other distant countries is worthy of remark. Early explorers eagerly sought for valuable food-plants, but the number of such as could be cultivated alive in Europe was very limited, and since the sixteenth century the attention of collectors has been fixed upon ornamental species simply because of the dearth of others.

European flower-gardens were enriched during the sixteenth century by the following American species: the so-called French and African marigolds (both from Mexico), sunflowers, the arbor-vitæ (Thuja 
occidentalis), Yucca gloriosa, and the Agave, misnamed the American Aloe.

About the same time the horse-chestnut, lilac, and syringa, or mock-orange, were first brought to central and western Europe, and with them the tulip, richest and most varied of flowering bulbs. All these reached Vienna from Constantinople, but how and when they were brought to Constantinople, or what were their native countries, are still doubtful questions. The horse-chestnut is believed to be a native of Greece, where it is said to grow wild among the mountains; probably it extends into temperate Asia as well. It is said to have reached Constantinople in 1557 . Longstanding tradition derives the lilac from Persia, but botanists say that it is also indigenous to parts of southeastern Europe. The garden-tulip is believed to be native to temperate Asia and also to Thrace; it is, of course specifically distinct from the wild tulip of northern Europe.

Chief among the travellers to whom we owe the acquisition of these favourite plants was Augier Ghislen de Busbecq, a Fleming, who was twice sent by the emperor as ambassador to the sultan. Busbecq was a keen observer and collector, and during his long and toilsome journeys was ever eager to pick up curiosities or to note new facts. Quackelbeen, a physician in Busbecq's suite, is named as another helper. The botanists Mattioli and Clusius, who presided in succession over the imperial gardens of Vienna, and Gesner of Zurich, described the plants; it is from them that we draw such imperfect knowledge as we possess of the way in which they were brought to central Europe. Clusius relates that Busbecq in 1575 received a parcel of tulip-seed from Constantinople, and being obliged to 
journey into France, left it with Clusius to be germinated. The tulips which came up were of various colours, an indication of long cultivation. The Turks, like the Persians, took great delight in gardens.

As North America became permanently occupied by the English, facilities for the transport of live plants to Europe steadily increased. Ships began to sail frequently to and fro, for the crossing of the Atlantic was but a small affair in comparison with the voyage round the Cape of Good Hope. Educated men here and there practised the learned professions in the American plantations, and among them a sprinkling of naturalists was found. Hothouses, the amusement of wealthy amateurs in Germany, France, and Holland, made it possible to protect the plants of mild climates from the winter cold of northern Europe. By the end of the seventeenth century our gardens had acquired many beautiful and curious American plants, besides a few from the East Indies, and not long afterwards the gains became so frequent that the botanists of Europe found it hard to name the new species as fast as they came in.

Lovers of horticulture will tolerate a little further information concerning the early use of hothouses. As soon as glass began to be employed in domestic architecture, the construction of warmed and glazed chambers, in which plants could be grown, was attempted. Writers of the first century A.D. mention them, and Seneca explains how the temperature might be kept up by hot water. This and other refinements of the Roman Empire passed into oblivion during the long decline of civilisation, but revived with the revival of the arts. In the sixteenth century William IV., Landgraf of Hesse, who is remembered, among other things, as a patron of the botanist Clusius, built himself a green- 
house, which could be taken down and put together again. A still more famous orangerie was that of Heidelberg, which served as an example to the kings and nobles of Europe. ${ }^{x}$ Henri IV. built one at the Tuileries, and long afterwards Louis XIV. had one at Versailles. Madame de Sévigné describes the orangerie of Clagny as a palace of Armida, and the most enchanting novelty in the world. The pine-apple was brought over from Barbadoes in the seventeenth century, and Evelyn speaks of having tasted the first pine-apple grown in England at the table of Charles the Second. For two hundred years the hothouse yielded no greater dainty, but rapid transit has now made pine-apples so cheap that it is no longer worth while to raise them in England. Fagon, who was during many years first physician to Louis XIV., was a considerable botanist. He was born and died at the Jardin des Plantes, and here, on his retirement from practice, he built hothouses; it would be interesting to know what he grew in them.

In the first half of the seventeenth century the younger Tradescant, who, like his father before him, was gardener to our Charles I., brought over from America the spider-wort, named Tradescantia after $h^{2},{ }^{2}$ the false acacia and the tulip-tree. The magnolias, or some of them, the Virginian creeper, and the scarlet Lobelia cardinalis were among the gifts received from North America about the

"Parkinson (1629) speaks of a stove or hothouse, "such as are used in Germany."

2 The graceful practice of naming genera of plants after benefactors to botany or horticulture was introduced by Father Plumier (1646-1704), who gave the names of L'Obel and Fuchs to the Lobelia and Fuchsia, and whose own name is appropriately borne by the frangipane (Plumeria). 
same time. The dwarf Lobelia (L. Erinus) was not brought over from the Cape of Good Hope till $\mathrm{I}_{75^{2}}$, and Lobelia splendens and fulgens (both from Mexico) not till the nineteenth century. One of the passion-flowers, which are all American, came over about this time; but Passiflora cærulea, the favourite ornament of the greenhouse, was only imported from Brazil in 1699. The evening primrose, the "convolvulus major and minor" (Ipomæa purpurea and Convolvulus tricolor), were other acquisitions from North America.

From the second half of the seventeenth century dates the introduction of the garden nasturtium (Tropæolum majus) from Peru; T. minus from Mexico had been brought over nearly a hundred years earlier. The sensitive plants and the pine-apple now became frequent objects in English greenhouses. John Evelyn and Bishop Compton were eminent patrons of English horticulture during this age.

The first half of the eighteenth century brought us the Aubretia and the sweet pea from southern Europe, the first Pelargoniums (scarlet geraniums) from the Cape, the camellia and Kerria japonica from the far east. The West Indian heliotrope was introduced in 17 I 3 ; the better-known Peruvian species not till 1757. Phloxes began to be imported from North America. Two or three foreign orchids were already known, and the number now began to increase ; but it was not till the nineteenth century that they came over in crowds. Our list gives no notion whatever of the number of new species added now and subsequently.

Of the accessions made during the latter half of the eighteenth century we must at least mention the mignonette from North Africa, white arabis from the Caucasus, the common rhododendron from Asia Minor. 
Rosa indica and Hydrangea hortensis from China, South African gladioli, which now begin to be numerous, and chrysanthemums from China and Japan. The first calceolarias were brought from great heights on the Andes, the first begonias from Jamaica, and the first fuchsia from Chili.

We can make only one remark about the multitudinous accessions of the nineteenth century. It is surprising to note how recently many established favourites have been brought to the knowledge of English gardeners. Anemone japonica (Japan) and Jasminum nudiflorum (China) date from 1844 , while the Freesias (Cape Colony) are as recent as 1875 . The dahlia, after two unsuccessful attempts, was established here as recently as 1815 ; Nemophila insignis came over from North America in 1822 ; the common musk and the monkey-plant a few years later; the chionodoxas (Crete and Asia Minor) in 1877 . The first of the foliage-begonias (Begonia rex from Assam) dates only from $185^{8}$, and the first of the tuberous species from 1865 .

Importation of foreign species has not been the only method by which English gardens have been enriched. New varieties and hybrids have been produced in bewildering numbers by the gardeners of Europe, and many of these far surpass in beauty the wild originals. Botanists and nurserymen could relate in great detail the steps by which our favourite roses, calceolarias, begonias, and cinerarias have been developed from a few natural stocks, sometimes of uninviting appearance.

Horticulture has repaid the debt which it owed to the explorations of botanists by furnishing countless observations and experiments bearing upon inheritance. When these have been properly co-ordinated, they will 
yield precious knowledge, not only to botanists but to all students of biology.

\section{Humboldt as a Traveller and a Biologist.}

The career of Alexander von Humboldt (b. I769, d. 1859), nearly coinciding with the period on which we are now engaged, was devoted to a gigantic tasknothing less than the scientific exploration of the globe. His great natural powers were first cultivated by wide and thorough training, not only in astronomy, botany, geology, mineralogy, and mining, which had an obvious bearing on his future enterprise, but also in anatomy, physiology, commerce, finance, diplomacy, and languages. Thus equipped, he sailed in r799 with the botanist Bonpland to South America, and spent the next five years in exploring the Orinoco and Amazon, the Andes, Cuba, and Mexico. The expedition marks an epoch in scientific geography. It is enough to mention the collection of data for the more accurate mapping of little-known countries, the exploration of the river-systems of equatorial America and the discovery of a water-connection between the Orinoco and the Amazon, the ascent of lofty mountains, the study of volcanoes, the description of remarkable animals such as the howler-monkey and the gymnotus (electric eel), and of remarkable plants, such as the bull's-horn acacia, whose enlarged and hollow spines are occupied by ants. ${ }^{x}$ After his return to Europe Humboldt published many important treatises on terrestrial magnetism, geology, meteorology, and plant-distribution. His new graphical method of isothermal lines did much for the study of climate in all its bearings. His Personal Narrative not only disseminated

s See the account of Cartagena in the Personal Narrative. 
much interesting information, but inspired a new generation of explorers. Darwin agreed with Hooker that Humboldt was the greatest of scientific travellers.

In I829 Humboldt traversed the Russian Empire from west to east, but the time allowed (half a year) was altogether insufficient for the examination of so vast a territory ; a few notable results were, nevertheless, secured.

After some fifteen or twenty years spent in European society, the inspiration drawn from long and arduous journeys in South America began to fail. The conversation of the salons, the troublesome flattery of the King of Prussia, and the propensity to write copiously, stimulated, of course, by the eagerness of the public to buy whatever so eminent an investigator chose to put forth, sterilised the last half of a career which had opened with such magnificent promise.

The best of Humboldt's work became absorbed long ago into the confused mass of general knowledge. This is the common fate (not by any means an unhappy one) of those who refuse to concentrate upon a single study. Among biologists he is chiefly remembered by his numerous discussions of plant-distribution, which are now considered less remarkable for what they contain than for what they leave out. While his travels were fresh in his mind, Humboldt was impressed by facts of distribution which could not be explained by present physical conditions, ${ }^{3}$ but the influence of climate as the more intelligible factor gradually assumed larger and larger proportions in his mind. The writers of textbooks, founding their teaching upon Humboldt, often overlooked altogether qualifications which he had

- See particularly his Essai sur la geographie des plantes (1805). 
shown to be necessary. When Darwin and Wallace pointed out how immensely important is the bearing upon present distribution, not only of the physical history of the great continents, but also of their biological history, and in particular of the interminable conflicts of races of which they have been the scene, naturalists began to perceive how inadequate are horizontal and vertical isothermal zones to explain all the striking facts of distribution, whether of plants or animals (see infra, p I 29).

\section{Premonitions of Biological Evolution.}

The eighteenth century had done much to impress the minds of men with an orderly development in sun and planets (Kant and Laplace), in the institutions of human societies (Montesquieu), and in the moral aspirations of mankind (Lessing). Many bold attempts had been made to trace a like orderly development in the physical life of plants and animals (Buffon, Erasmus Darwin, etc.), but neither was the proof cogent nor the process intelligible. Cautious people therefore, and those whose prepossessions inclined them to adopt a very different origin for terrestrial life, held during all this time a position of some strength against speculative philosophers who tried to explain the variety and perfection of living nature by unconscious and unintelligent factors.

About the year 1840 the doctrine of the fixity of species seemed to be victorious. Cuvier's knowledge and skilful advocacy had a few years before overpowered Geoffroy St. Hilaire's conception of a common plan of structure pervading the whole animal kingdom, and the new Philosophie Anatomique was laid on the shelf, side by side with the Philosophie Zoologique of 
Lamarck, the Zoonomia of Erasmus Darwin, the Théorie de la Terre of Buffon, and the Protogaa of Leibnitz. Yet even then a spectator who was fully informed and at the same time gifted with uncommon foresight might have satisfied himself that the victory of evolution had become inevitable.

Cuvier's memorable descriptions of the extinct vertebrates of the Paris basin had founded the new science of Palæontology, and though neither he nor anyone else was aware of the fact, had made it possible to trace, very imperfectly no doubt, the descent of a few modern ungulates. Lyell's Principles of Geology (1830-3) had shaken the belief in catastrophes repeatedly breaking the succession of life on the earth. It was rapidly becoming impossible to maintain that the account of creation given in the book of Genesis was even approximately accurate. In the year 1828 Baer had almost 'made up his mind that the facts of development pointed to a common plan of structure, perhaps to a common origin, for each of the great types of animal life. ${ }^{x}$ Darwin's Journal had appeared in 1839 , and though the explanations which it offered were not inconsistent with prevalent opinion, evolutionary suggestions were introduced into the second edition of 1845 . Lyell at least was already aware that the voyage of the Beagle had impelled Darwin to examine afresh the accepted philosophy of creation. Between 1840 and 1850 faint signs of coming change struck orthodox reasoners with misgiving and gave increased confidence to freethinkers. A few German botanists and zoologists declared against the immutability of species. The

3 Baer's expressions are so guarded that his real opinions in 1828 can only be surmised. He never accepted a consistent theory of organic evolution. 
Vestiges of the Natural History of Creation, which might be called a premature explosion, dates from 1844. Hofmeister (see supra, p. I09) put forth a detailed comparison of the flowering plants with the higher cryptogams, which strongly suggested a theory of descent with modification, and is unintelligible on any other basis. He indicated no such interpretation himself, being content to establish the new homologies; but the Origin of Species, as soon as it appeared, commanded his entire sympathy.

Among those who rejected fixity of species and special creation before 1859 none was so clear or so outspoken as Herbert Spencer, who thought out for himself an evolutionary philosophy which was not shaken by Darwin. It is impossible to discuss in this place the question whether or not it was shaken by Weismann.

Agassiz's Essay on Classification, which was published in October, 1857, was the last manifesto issued before the Origin of Species by the party which stood out for fixity of species, the last polemic which made De Maillet, Lamarck, and the Vestiges its targets. It is an eloquent but inconsiderate defence of an extreme position. According to Agassiz every branch, class, order, family, genus, and species represents a distinct creative thought ; every mark of affinity, every appearance of adaptation to surroundings, has been expressly designed. Extinction and replacement of species are due to the direct intervention of the Creator; pterodactyls are prophetic types of birds, and indicate that divine wisdom had foreseen the possibility of an advance in the organisation of animals which was not immediately practicable; the mallard and scaup duck occur on both sides of the Atlantic because they were 
simultaneously but separately created in Europe and North America; the teeth of the whale, which never cut the gum, are the result of obedience to a certain uniformity of fundamental structure. Explanations like these removed no difficulties and suggested no inquiries. In the hot debates which ensued the Essay on Classification was rarely mentioned. 


\section{PERIOD V. \\ (I859 AND LATER)}

\section{Period V.}

WE do not attempt to characterise our last period, nor to describe its biological achievement. It seems better to devote the whole of our scanty space to the scientific careers of Darwin and Pasteur, in which so much past effort culminated, and from which so much progress was to spring.

\section{Darwin on the Origin of Species.}

Setting aside as superfluous and we might say impossible, under our conditions of space, all attempt to restate the evidence on which Darwin based his great argument, we shall here try to show that the Origin of Species shed a new light upon many biological facts, combined many partial truths into one consistent theory, and gave a great stimulus to further inquiry.

I. Classification and Affinity. -The sixteenth-century herbalists and still earlier writers (see p. I7) recognised a property of affinity, by which plants were associated in natural groups. Bock $\left(1_{546}\right)$ tried to bring together all plants which are related (verwandt) to one another, but similarity of any kind was with him a proof of affinity; it did not shock him to place the dead nettles next to the stinging nettles. L'Obel gave names to several families of flowering plants which are still admitted as natural. Ray spoke of the affinity (cognatio) between plants, and his affinity was a thing 
not to be violated for the sake of practical convenience or logical rules, but he was unable to explain what he meant by it. Linnæus tried to illustrate affinity between plants by contiguous provinces on a map, a better metaphor than the linear scale, for the scale can only express affinity on two sides, while the map can express affinity on many. His practical experience of classification taught him a truth, shocking at first sight to the logician ${ }^{\mathrm{x}}$-viz., that the characters which serve for the definition of one genus may be useless for the definition of the next, and he laid it down that the characters do not make the genus, but the genus the characters. After Linnæus we find for a long time no advance in the philosophy of natural classification. Cuvier (1816) is even retrograde, for he sets aside the maxims of Linnæus, maintains that adaptive characters (characters closely related to the conditions of life) are relatively constant, and that large groups should be defined by characters drawn from organs of great physiological importance. These decisions of his are repudiated by later naturalists.

The key to the affinity puzzle which had so long baffled thinking naturalists was at last supplied by Darwin, who explained that "the natural system is founded on descent with modification; that the characters which naturalists consider as showing true affinity between any two or more species, are those which have been inherited from a common parent, all true classification being genealogical ; that community of descent is the hidden bond which naturalists have

- Tilius of Wittenberg, who published in 1766 what is commonly called Bode's law of planetary distances, objected to the Linnean system on the ground that it multiplied the principle of division. (De divisione animalium generali, 1760.$)$ 
been unconsciously seeking, and not some unknown plan of creation, or the enunciation of general propositions, and the mere putting together and separating objects more or less alike."

Natural groups, large or small, result from the longcontinued operation of divergence, the survival of some, and the extinction of others; they are to be respected as facts; they are not created by definitions, which only serve to indicate and remind; any character, however trifling, will suffice, if only it is constant and distinctive.

The conflict between natural classification and logic is apparent only. Logicians say that in classifying books, for instance, you may take any property you please, subject, size, etc., as the basis of your arrangement, but having made your choice, you must adhere to it for all divisions of the same rank. Naturalists seem to say something different, for they are agreed that what they call "single-character classifications," in which one property is adhered to throughout, are unnatural. The fact is that a natural classification always rests upon one and the same property-viz. affinity, i.e. relative nearness of descent from some common ancestor. Every natural classification, like every logical classification, proceeds upon a single basis, and the failure of the single-character classifications is due to their displacing affinity by some definition.

The effect of the Origin of Species upon zoological and botanical systems has been revolutionary. Furnished with a new and intelligible meaning of the word natural, and with new criteria of naturalness, systematists have during the last fifty years worked hard to

Origin of Species, chap. xiii. 
create classifications which admit of being thrown into the form of genealogical trees. Wide gaps in the geological history of life render the task difficult beyond expression, but much has already been accomplished. Newly discovered forms (especially the fossil Archæopteryx and the Cycadofilices) and more fully investigated forms, far too numerous to be specified, have established links between groups which formerly seemed to be wholly independent. Unnatural assemblages based on pre-determined characters (Radiates, Entozoa, Birds of prey, etc.) have been replaced by groups which are at least possible on evolutionary principles. Almost every working naturalist will admit that the progress of zoological and botanical system during the last two generations has done much to fortify the Darwinian position.

2. Embryology.-Baer in 1828 was possessed of all the embryological facts which Darwin used in support of his theory of evolution; in particular, he was well acquainted with the most striking fact of all-viz., the presence in embryo mammals and birds of a series of paired clefts along the sides of the neck, between which run vessels arranged as in gill-breathing vertebrates. The vessels had been figured by Malpighi; the clefts had been discovered by Rathke, who had no hesitation in calling them gill-clefts and the vessels gill-arches. Nor had Baer, who nevertheless to the end of his long life refused to accept the one explanation which gives meaning to the facts-viz., that remote progenitors of mammals and birds breathed by gills. Few embryologists have since felt such a scruple. The adaptation to gill-breathing is obvious; is gill-breathing noze practised by any mammal or bird? Certainly not. Is it destined to be practised by their descendants at 
some future time? To say nothing of the danger of putting forth any such prophecy, it involves all the consequences of descent with modification. The opponent of evolution may as well admit at once that the gill-breathing was practised in time past. As an example of the same kind taken from plants, we may quote the trifoliate leaves of the furze-seedling, which, though absent from the full-grown furze, are frequent in the family (Leguminosæ) to which it belongs. The general similarity of vertebrate embryos, of insectembryos and of dicotyledonous seedlings, is also worthy of note. We may suppose that early embryos, being largely or wholly dependent on food supplied by the parent, and perhaps protected by the parent as well, escape the pressure of the struggle for existence, and are often not urgently impelled to produce adaptations of their own. In these circumstances it is intelligible that features inherited from remote ancestors should persist. If, however, early independence is demanded by the conditions of life, the embryo may develop temporary adaptations, wanting in the parent and in embryos of allied groups. Larval adaptation is as much a part of the economy of nature as the retention of ancestral structures which have been lost by the adult.

3. Morphology. - Let us next consider the light which the Origin of Species throws upon homologous parts. No example will serve our purpose better than the very familiar one of the fore-limbs of different vertebrates, the arm and hand of man, the wing of the bat, the wing of the bird, the pectoral fin of the fish, and the paddle of the whale. These limbs, adapted for actions so diverse as grasping, running, flying, and swimming, nevertheless exhibit a common plan, evident at a glance, except 
in the pectoral fin of the fish. But why a common plan? Of what advantage is it to an animal that its wing, paddle, or hand should reproduce the general plan of a fore-foot? Why should the digits of the land vertebrates never exceed five? Why should the thumb never have more than two free joints? It would be hard to find a satisfactory answer to these questions in any book earlier than the Origin of Species; no student of the Origin of Species finds any difficulty in answering them all. The common plan has been transmitted from type to type by inheritance, and its features are derived from an unknown common ancestor.

The new conception, that structures inherited from remote ancestors may be incessantly modified by the conditions of life and by mutual competition, is the key to the chief problems of morphology. No limited collection of examples can substantiate so wide a proposition as this. Those who have made themselves familiar with old text-books of comparative anatomy will recollect how dry, or else how inconclusive, was pre-evolutionary morphology, how vague were the references to some ideal archetype, or to climate, or to the ancient conditions of the earth's surface ; how often exclamations of admiration for the marvels of nature or Providence were substituted for clear explanations. Cuvier, it is true, was both precise and reasonable; but how little he was in a position to explain! His "empirical" comparative anatomy could throw no direct light upon origins or transformations; his "rational" comparative anatomy was practicable only in a few easy cases.

4. Geographical Distribution.-The facts of distribution were handled in the Origin of Species with great originality. It was shown that they support, and indeed require, some doctrine of organic evolution. 
The succession in the same area of the same typesarmadillos succeeding armadillos in South America, marsupials succeeding marsupials in Australia-was enough of itself to render independent creation highly improbable. This was not all. Darwin's mind being charged with facts and reasonings, the accumulations of many years of travel and meditation, he sketched in rapid outline conclusions which have given a new form to the distribution question. The subject had hitherto been treated by collecting masses of facts and interpreting them by recent physical geography; Darwin showed that the history of the continents and islands may be far more influential than soil, elevation, or climate.

The scientific discussion of the facts of distribution is as old as the sixteenth century, when L'Obel pointed out that the mountain plants of warm countries descend to low levels in the north. Linnæus remarked that fresh-water plants and alpine plants are often cosmopolitan. Another early and well-founded generalisation is the statement of Linnæus that the plants common to the old and the new world are all of northern range. Buffon made the same remark about the animals, and offered the probable explanation-viz., that since the two great land-masses approach one another only in high latitudes, it is only there that animals have been able to cross from one to the other.

In the nineteenth century theories involving prodigious changes of land and sea were much in the minds of naturalists. Darwin lost his temper (a rare thing with him) over the land-bridges, hundreds, or even thousands, of miles long, which were created in order to explain trifling correspondences in the population of distant countries. A belief in the comparative stability 
of the great continents and oceans has since prevailed, and it is now recoginised that the means of dispersal of species are greater than was once supposed.

The discovery, about the year 1846 , of the marks of ancient glaciers in all parts of northern Europe, and the acceptance of an İce Age, had a still greater influence upon the teaching of naturalists. Edward Forbes ${ }^{\mathrm{x}}$ put forth a glacial theory to account for the present distribution of plants of northern origin. Glacial cold, he maintained, had driven the arctic flora far southward. When more genial conditions returned, most of the northern plants retreated towards the Pole, but some climbed the mountains and gave rise to an isolated alpine flora. Darwin, whose unpublished manuscripts had anticipated Forbes's theory, believed that the whole earth became chilled during the Ice Age, and that the fauna and flora of the temperate zone reached the tropics. His argument, which is contained in chap. xi. of the Origin of Species, is now generally accepted in principle, though opinions differ on many points of detail. Some think that he extended too widely the effects of glacial cold, exaggerated the resemblance of the arctic and alpine fauna and flora, and attributed the extinction of the northern species in the intermediate plains too exclusively to climatic causes.

One paragraph in the extremely condensed discussion on geographical distribution which we find in the Origin of Species calls attention to the dominance of forms of life "generated in the larger areas and more efficient workshops ${ }^{2}$ of the north." The power which inhabitants

Geol. Survey Memoirs, $18+6$.

- By a curious and no doubt accidental coincidence, Darwin employs the same remarkable metaphor which had occurred to Iordanes in the sixth century A.D. Iordanes calls the north the oficina gentium. 
of the great northern land-mass of the old world, and in a less degree those of North America, possess, and have long possessed, of driving out the inhabitants of the southern continents is one of the most important factors in the peopling of the earth with new races of land-plants and land-animals. Races of men, modes of civilisation, religious faiths, all follow the same rule, which has no doubt prevailed ever since land came to predominate in the northern hemisphere and water in the southern hemisphere. In the life of the sea and the fresh waters no dominance of northern forms has been detected.

5. Palcontology. -We must not claim for Darwin more than a modest share in the vast extension of palæontological knowledge which the last fifty years have created. A profusion of new materials has been acquired by the diligence of collectors working on a scale previously unattempted. But though the accumulation of materials is the work of others, the interpretation has been guided by the principles of Darwin. The evolution of the horse has now been so fully worked out that it would bear the whole weight of a doctrine of descent with modification, though it could not by itself reveal the process by which the modification had been effected.

Darroin on Adaptations. - The adaptation of living things to their surroundings has always been a favourite branch of natural history, underrated only by those whose studies are little calculated to inflame the curiosity. Many eminent naturalists have made the interpretation of natural contrivances their chief aim. Darwin equalled the best of his predecessors in accuracy, range, and ingenuity, while he surpassed them all in candour. No one has done so much to vindicate the 
study of adaptations from all suspicion of triviality, for no one before him had seen so clearly how all new species arise by adaptation of pre-existing ones. It is by adaptation that new forms of life arise; it is inheritance which preserves old ones.

Socrates, Swammerdam, and Paley had drawn from the adaptations of nature proofs of the omnipotence and beneficence of the Creator. Darwin, while admitting that every organism is exquisitely adapted to its own mode of life, believed that the adaptations have been perfected by slow degrees, and that they cannot be proved to have been consciously devised. This interpretation deprives the theologian of valued arguments, but at the same time rids him of difficulties. Even before Darwin's day some few natural theologians had the courage to bring forward instances of the harshness of nature. Kirby and Spence ${ }^{x}$ thought that no injustice was done to certain predatory insects by comparing them to devils. Others blessed the mercy of heaven, which, after creating noxious animals, created others to keep them in check. Darwin, when reflecting upon the odious instincts which urge the young cuckoo to eject its foster-brothers, some species of ants to enslave others, and a multitude of ichneumons to lay their eggs in the bodies of live caterpillars, found it a relief to be able to shift the responsibility to an unconscious natural process. ${ }^{2}$.

In his autobiography Darwin remarks that he had thought it almost useless to endeavour to prove by indirect evidence that species had been modified until he was able to show how the adaptations could be explained. Some of them alarmed him by their difficulty;

Introduction to Entomology, Introductory Letter.

- Life and Letters, Vol. I., chap. ii. 
to suppose that the eye, with all its inimitable adjustments, had been formed by an unconscious natural process seemed to him absurd until he had traced a good many intermediate steps between the mere colourspot and the eye of the eagle. He writes to Asa Gray (September 5,1857 ) that the facts which had done most to keep him scientifically orthodox were facts of adaptation, the pollen-masses of Asclepias, the mistletoe with its pollen carried by insects and its seeds by birds, the woodpecker exquisitely fitted by feet, tail, beak, and tongue to climb trees and capture insects.

The student of adaptations has no longer a moral thesis to maintain; he tries to understand how a contrivance acts, what advantage it confers upon its possessor, and by what steps it was perfected. The minute variations of species are as capricious as the form of the stones which accumulate at the foot of a precipice; natural selection turns fortuitous variations to account for the advantage of the species as a builder might turn to account the shapes of the stones. Man himself can employ variations for frivolous or even base purposes, as when he produces toy-spaniels or bulldogs. ${ }^{x}$ The adjustments of organic structures often move our wonder by their perfection. One reason why they so far exceed the adjustments made by wind, frost, or moving water is that the process has been so protracted; in a worm or an insect we see the last stage of an adaptation which has been continuously at work for untold geological periods. Another reason is that the thing adapted is alive, sensitive, and capable of responding to the subtlest imaginable influences.

Darwinism and Non-biological Studies.-The theory

- Darwin, Variation of Plants and Animals under Domestication, Concluding Remarks. 
of organic evolution has already produced a visible effect upon non-biological studies. Bagehot has applied Darwinian principles to the interpretation of history and politics. Philologists recognise a process very like that of natural selection in the modification of words. The usages of language are inherited from generation to generation; one idiom competes with another, that persisting which best suits the temper or the convenience of the nation. Philology has like zoology its chains of descent, its breeds or dialects, its species or languages, its fossils (dead languages), its dominant and declining forms, its vestiges (such as letters, still retained, though no longer sounded). Psychology is already in part experimental and evolutionary, and seems as if it would attach itself more and more closely to physiology, detaching itself in the same measure from metaphysics. The change may be attributed to two growing convictions: (I) That the experimental method is more trustworthy than the speculative; and (2) that the mind of man is not a thing apart, but an enhanced form of powers manifest in the lower animals. Sociology finds its most practicable and its most urgent sphere of work in the problems of selection and race, which are naturally examined in the light of Darwinian principles. The new study of Comparative Religion aims at the impartial examination of all forms of religious experience, and is evolutionary in proportion as it is scientific. One of its conclusions, by no means universally accepted as yet, is the recognition of conscience as "the organised result of the social experiences of many generations" (Galton). Comparative Religion can already show in outline how by slow degrees magical rites passed into polytheistic worship, how polytheism became simplified 
and elevated, and how ethical motives at length became influential if not predominant.

\section{Pasteur's Experimental Study of Microbes.}

The same difficulty arises with Pasteur as with Darwin ; his life-work has already been described often and well. Readers unversed in science have only to turn to the Vie de Pasteur, written by his son-in-law, Vallery-Radot, to find a luminous account, giving just so much detail as makes the discoveries intelligible and interesting. If shorter sketches are demanded, they exist. We must therefore above all things be brief, and content ourselves with reminding the reader of facts which, in spite of their recent date, are as well known as anything in the history of science.

Chemists will claim Pasteur as one of their number, and we do not dispute the claim. Trained in experimental methods by the chemical laboratory, he devoted his best powers to the study of living things, and, without ceasing to be a chemist, became one of the greatest of biologists.

Pasteur's chief work was of course the experimental investigation of living particles which float in the airwhat we may call live dust. Before his day such particles had been seen, named, and classified; some few had been studied in their action and effects. Most of them are plants of low grade, simplified to the last point for the sake of minuteness, on which their ready dispersal depends.

Yeast.-Van Helmont, early in the seventeenth century, when the microscope had not yet become an instrument of research, attempted to investigate the fermentation of beer, and made acquaintance with the properties of the gas which is evolved, his gas silvestre, 
which was afterwards called fixed air, or carbonic acid. Leeuwenhoek about 1680 examined yeast by his microscopes, and discovered that it is made up of globules which often cohere, and that these globules give off bubbles of gas. Then comes a long interval, during which nothing was done to elucidate the process of fermentation. It was not till 1837 that CaignardLatour and Schwann, independently of each other, showed that yeast-globules multiply by budding, and are therefore to be set down as living things, probably plants of a simple kind. Twenty years more passed without sensible progress; during this time chemists were striving to prove that the alcohol was produced by contact-action, and that the globules were of no practical importance. By the year 1860 Pasteur was engaged upon the problem. It is well known that he arrived at a firm conviction that living yeast-cells are essential to the production of alcohol. It has since been discovered that the enzyme (unorganised ferment of older writers) secreted by living yeast-cells can change sugar into alcohol after the cells themselves have been destroyed, and that other plants besides yeast-cells secrete the same enzyme when deprived of oxygen.

Bacteria.-Another and even more important chapter in the history of air-wafted organisms was opened by the indefatigable Leeuwenhoek. In 1683 he wrote a letter to the Royal Society which makes mention for the first time of bacteria, which he found upon his own teeth, and described as minute rods; some of them moved with surprising agility. For nearly two hundred years little more was done. A few bacteria were named and classified, and there the matter rested until Schwann proved experimentally that putrefaction is just as much 
the work of living microscopic organisms as alcoholic fermentation. In 1857 and the following years Pasteur not only confirmed the work of Schwann, which had been received by the majority of chemists with distrust, but went on to show that the lactic, butyric, and ammoniacal fermentations also depend upon the activity of bacteria. The happy thought struck him that they might be studied alive - a possibility which he soon realised in practice, and upon which the new science of bacteriology largely rests. From about the year 1873 he began to occupy himself seriously with contagion, which he suspected to be connected with specific aerial germs. Davaine and others had years before observed in the blood of sheep and cattle which had died of "charbon" (anthrax) minute "bâtonnets" (bacilli). Pasteur's published results induced Davaine to ask whether his "bâtonnets" might not be the cause of "charbon." Again, it was Pasteur's results which induced Lister to make experiments in the field of antiseptic surgery. Pasteur wasted no time upon the curiosities of bacterial life. His first studies on fermentation suggested that specific diseases may be propagated by microscopic germs, and that such cases of spontaneous generation as had hitherto escaped refutation might be explained by the access of live dust. The identification and biological history of the organisms interested him only as a step towards sure methods of controlling, and, if necessary, destroying, them ; of mitigating their virulence by inoculation; of rendering animals immune against them; or of stamping out the disease by isolation. All this is happily too well known for repetition here. The story, with its many dramatic incidents, can be read in the pages of Vallery-Radot.

Hardly less important than the bacteria which destroy 
life or endanger the products of human industry are the beneficent forms, some of which have in all ages cooperated with man, while others can only be employed by those who possess knowledge and skill. None are so important to our welfare as the bacteria which renew the fertility of the soil. But for the soil-bacteria farmyard manure would be useless to the crop, for it is they which render it fit for assimilation. Now the bacteria of the soil have their natural enemies, the most mischievous being certain Protozoa, such as Amœba and its kindred. As soon as this fact was grasped, likely remedies were thought of ; indeed, one remedy was suggested without any guidance from theory by a vine-grower of Alsace, who treated his soil with carbon disulphide to destroy phylloxera, and found that in so doing he had notably enhanced its fertility. Heating to the temperature of boiling water destroys the soilprotozoa and at the same time the bulk of the soilbacteria. The bacteria, however, soon multiply more than ever by reason of the absence of their enemies, and a soil cleared of protozoa yields for a few years appreciably richer crops. Of other useful bacteria the briefest notice must suffice. Wine, beer, cheese, and tobacco owe to certain of them distinct flavours, for which the customer is willing to pay high. Leather in certain stages of manufacture, indigo, and woad require the access of other forms. If we also bear in mind the part which yeast plays in the every-day manufacture of bread, wine, and beer, and the part which the vinegarmould plays in the manufacture of acetic acid, we shall get some notion of the industrial importance of the various micro-organisms. Not a little of the control which we exercise over them we owe directly or indirectly to Pasteur. 
The career of Pasteur exhibits a striking unity. His first research, which dealt with a subject so remote from the ordinary studies of the biologist as the crystalline forms of tartrates, made him acquainted with activities, hitherto unsuspected, of minute forms of life. The hope of aiding the industries of Lille, Orleans, and France kept him long engaged upon ferments. If he turned aside to examine the superstition of spontaneous generation, it was to protect his methods from misconstruction. An apparent break in his programme of work was forced upon him by the silkworm pestilence. It proved to be no real break, for pébrine and flacherie were both bacterial diseases. At a comparatively early date (1863) he wrote that his chief ambition was to throw light on the spread of contagious diseases; he could not then foresee that he was destined, not only to elucidate, but in a measure to control them. Around his tomb are inscribed words, each of which commemorates a signal service to his fellow-men : " 1848 , Molecular dissymetry. 1857, Fermentations. I862, Spontaneous generation. ı $86_{3}$, Studies of wine. 1865 , Silkworm diseases. $187 \mathrm{r}$, Studies on beer. 1877 , Contagious diseases of animals. I880, Vaccination against contagious diseases. 1885 , Prevention of hydrophobia." These manifold researches form a continuous chain, each being linked to what precedes and follows. The devotion by which all were inspired, beginning with devotion to science and the fatherland, ended by embracing all mankind.

Biology, which in the sixteenth century sent out only a few feeble shoots, has now become a mighty tree with innumerable fruit-laden branches. The vigour of its latest outgrowths encourages confident hopes of future expansion. 


\section{CHRONOLOGICAL TABLE}

$$
\text { I } 200-1850
$$

(The date of a discovery is the date of first publication, where this is known.)

1202. Arabic numeration introduced into Europe by Leonardo of Pisa (Liber Abaci); it spread slowly, and did not become universal till the midule of the seventeenth century.

I 2 14-1294. Roger Bacon.

$1265^{-1} 3^{21}$. Dante.

1271-1295. Travels of Marco Polo.

1304-1374. Petrarch.

1324 ? 1384 . Wycliffe.

1340?-1400. Chaucer.

I 4 I0. Wood-engraving introduced about this time.

1423. Earliest known block-book.

1450? Mazarin Bible, printed by moveable types.

1453. Taking of Constantinople by the Turks.

1466?-1536. Erasnuus.

147x-1528. Albert Durer.

1472-1543. Copernicus.

$1475^{-1} 5^{6} 4$. Michael Angelo.

1477-1576. Titian.

1483-1520. Raphael.

1483-1546. Martin Luther.

1492.

First voyage of Columbus.

I $+97-1498$. Voyage of Vasco da Gama to India by the Cape.

1516.

More's Utopia.

1517. Luther's theses.

1519-1521. Mexico conquered by Cortez.

1519-1522. Circumnavigation of the globe by a ship of Magellan's squadron. 
1530-1536. Brunfels' Herbarum viva eicones. Confession of Augsburg.

1532. Peru conquered by Pizarro.

I534.

Society of Jesus founded by Loyola.

I539.

Bock's New Kreutterbuch (without figures); and ed. (with figures) I 546.

1542. Fuchs' Historia Stirpium.

1543.

1545.

$1545^{-1} 5^{64}$.

Copernicus' De Revolutionibus Orbium Celestium. Vesalius' Fabrica Humani Corporis.

1547 .

1551 .

Botanic garden at Padua founded.

Council of Trent.

Botanic garden at Pisa founded.

Belon's Histoire Naturelle des estranges porssons marins.

1551-1587. Gesner's Historia Animalium.

1553 .

Belon's De aquatilibus, etc., and his Observations de plusieurs singularitez, etc. (Travels in the Levant.)

1554 .

Rondelet's De piscibus marinis.

1555 .

Belon's Histoire de la nature des Oyseaux. Rondelet's Universa aquatilium Historia pars altera.

1564-1616. Shakespeare.

1564-1642. Galileo.

1566.

Revolt of the Netherlands.

157 .

Battle of Lepanto (advance of the Turks checked).

1571-1630. Kepler.

1572 .

1576 .

Massacre of St. Bartholomew.

L'Obel's Plantarum seu Stirpium Historia and Adversaria.

1577-1580. Drake's circumnavigation.

1583 .

1588 .

Cesalpini's De Plantis.

I $596-1650$.

The Invincible Armada.

1600.

1601 .

Descartes.

Olivier de Serres' Théâtre d'Agriculture.

1605 .

Clusius' Rariorum plantarum Historia.

Clusius' Exoticorum libri decem. 
r6ro.

1614 . $1618-1648$ 1620. 1621 . 1623 . 1626 . 1628 .

1635 . 1638 .

1642 . 1642-1 727 1643 . 1650 ?

1653. 1660.

r66r.

$166_{5}$. i666.

I 668 . I669. $1671-1677$. $1672-1679$. I673.
Galileo's microscope invented about this time. Napier's Logarithms.

Thirty Years' War.

Voyage of Mayflower. Bacon's Novum Organum. Aselli re-discovers the lacteals.

C. Bauhin's Pinax Theatri Botanici. Jardin des Plantes founded.

Harvey's De motu cordis et sanguinis published the lectures had been delivered in $161_{4}$.

French Academy founded.

First authenticated cure of fever by chincona bark (in Peru).

New Zealand and Van Dieman's Land discovered by Tasman.

Newton.

Barometer invented by Torricelli.

Air-pump invented by Otto von Guericke. Thoracic duct discovered by Pecquet.

Lymphatic vessels discovered by Rudbeck.

Royal Society founded; incorporated 1662. Boyle's Spring of Air and its Effects. Ray's Catalogus Plantarum circa Cantabrigiam nascentium.

Boyle's Sceptical Chemist. Passage of blood through capillaries observed by Malpighi.

Hooke's Micrographia.

Académie des Sciences founded. Composition of white light discovered by Newton.

Redi on the Generation of Insects.

Swamnerdam's Historia Insectorum Generalis. Malpighi's De Bombyce.

Grew's Anatomy of Plants; collected in one volume, 1682 .

Malpighi's Anatome Plantamu; collected in his Opera Onınia, 1686.

Malpighi's De formatione pulli in ovo. Lecuwenhoek's first paper published by the Royal Society. 
1675 .

Greenwich Observatory founded. Velocity of light determined by Roemer.

1676. Willughby's Ornithologia.

1677.

Spermatozoa discovered by Hamm.

1680.

1682 .

1683 .

Yeast-cells discovered by Leeuwenhoek.

1687.

Ray's Methodus Plantarum.

1691-1694.

1702.

$1711-1776$.

Bacteria discovered by Leeuwenhoek.

$1723-1790$.

Newton's Principia.

1725 .

Camerarius on the sexes of flowering plants.

Hydra discovered by Leeuwenhoek.

Hume.

I734-1742.

Adam Smith.

Vico's Scienza Nuova.

1736-1819.

1737 .

Réaumur's Histoire des Insectes.

Watt.

Linnæus's Systema Natura; last edition by Linnæus, 1766. Linnæus's Genera Plantarum.

1737-1738. Swammerdam's Biblia Natura published; written long before.

1738. Linnæus's Classes Plantanum.

1740-1761. Roesel von Rosenhof's Insecten-Belustigungen begun.

1744. Trembley's Polype d'eau douce (Hydra).

1745 .

1748 .

Bonnet's Traité d'Insectologie (aphids, Nais).

1749-1804. Buffon's Histoire Naturelle, the last volumes posthumous.

$175^{2}$.

Identity of lightning and electricity demonstrated by Franklin.

1753.

British Museum founded.

1755 .

Black's experiments on carbonic acid and alkalis.

1759.

C. F. Wolff's Theoria Generationis.

1760.

1770.

Lyonet's Traité Anatomique, etc. (larva of goatmoth).

1775 .

New South Wales discovered by Captain Cook. Priestley's experiments on the restoration by green leaves of air vitiated by combustion or 
respiration, and on "dephlogisticated air" (oxygen). Adam Smith's Wealth of Nations.

1777. Spallanzani's experiments on the spontaneous generation of minute organisms.

1781. Uranus discovered by Herschel. Leroy's Lettres sur les Animaux (first collected edition).

1784, Cavendish's Experiments on Air (composition of water).

1785. Hutton's Theory of the Earth.

1787-1789. Lavoisier's Méthode de nomenclature chimique (1787) and Traité élémentaire de chimie (1789).

1789 .

First French Revolution. A. L. de Jussieu's Genera Plantarum. White's Natural History of Selborne.

1790. Goethe's Metamorphosen der Pflanzen.

1791.

Galvani's experiments on animal electricity.

1792.

Sprengel's Entdeckte Geheimniss der Natur. F.

Huber's Nouvelles Observations sur les Abeilles.

1796. Cuvier on recent and fossil elephants.

1798.

Jenner's Inquiry (vaccination against small-pox).

Lithography invented by Senefelder.

1799. William Smith's Order of the Strata and their Embedded Organic Remains.

1799-1825. Laplace's Mécanique Celeste.

I800. Volta's electric pile.

1807 .

Dalton's Atomic theory. Davy's decomposition of potash and soda.

$18 \mathrm{I}$ r.

Motor and sensory roots of spinal nerves discovered by Bell.

1812. Cuvier's Ossemens Fossiles.

1816. Cuvier's Regne Animal.

1819. Electro-magnetisn discovered by Gersted. Chamisso's De Salpa.

1823-1831. Pollen-tubes traced to the ovule (Amici, Brongniart, Robert Brown).

1827. Discovery of mammalian ovum by Baer.

1828-1837. Baer's Entwickelungs-geschichte.

1330-1832. Lyell's Principles of Geology. 
1835. Cell-division in plants observed by Mohl.

1837. Caignard-Latour's demonstration that alcoholic fermentation is due to living organisms.

I 839. Schwann and Schleiden's cell-theory.

1840-1849. Joule's determination of the mechanical equivalent of heat.

I841. Faraday's discovery of electric induction.

1846. Discovery of Neptune by Leverrier and Adams. Agassiz and Buckland's announcement of extensive glaciation in Scotland.

1848. Discovery of the antheridia of ferns by Suminsky. 1849-1851. Hofmeister's comparative studies of the higher cryptogams and the flowering plants.

1809-1882. Charles Darwin.

1822-1895. Louis Pasteur.

\section{THE SUB-DIVISIONS OF BIOLOGY}

Morphology :

Anatomy.

Minute Anatomy.

Comparative Anatomy.

Embryology.

Physiology (including adaptations to the conditions of life).

Psychology of Animals.

Classification.

Geographical Distribution.

Palæontology.

All these divisions, except Psychology, apply both to plants and animals. Many other modes of division have been proposed. 


\section{BIBLIOGRAPHY}

[It will be readily understood that the literature of Biology is enormous, as a single fact will show. Half a century ago Dr. Hagen compiled a list of books and papers relating to Entomology alone. Though far from complete, it filled a thousand pages, and if brought down to the present date would probably fill a thousand more. The student who tries to follow in some detail the history of any branch of Biology must read books in half-a-dozen languages, and work continually in large public libraries. We shall attempt no more in this place than to mention a few books which can be procured and read by those whose leisure and knowledge of the subject are limited.]

\section{History of Biology or its Str-Divisions.}

Carus, V. Geschichte der Zoologie. $\quad \mathrm{I}^{8} 64$ foll.

The French translation by Hagenmuller and Schneider (1880) will be preferred by some.

Cuvier, G. Histoire des Sciences Naturelles. Publiée par M. de Saint-Agy. Two vols., i84i. Taken down from Cuvier's lectures, but not revised by him.

Though far from trustworthy (the first volume especially), this history mentions many interesting facts, and suggests inquiries which may be pursued with advantage.

Foster, Sir M. Lectures on the History of Physiology. Cambridge Natural Science Manuals, 1901.

Green, J. R. History of Botany, 1860-19oo. A continuation of Sachs's History. Clarendon Press, I909.

Sachs, J. History of Botany, 1530-60. English translation. Clarendon Press, 1889.

An outline of the History of Palæontology is prefixed to Zittel's Hundbuch der Palceontologie, Bd. I. (1876-80). English translation, 1900-2.

The ninth edition of the Encyclopadia Britannica often contains useful references. See for example the articles Biology, Embryology, Medicine, Parasitism, and Zoology.

Biographical dictionaries are of course indispensable. The Dictionary of National Biography, the Biographie 
Universelle, the Nouvelle Biographie Universelle, the Allgemeine Deutsche Biographie, and the Biographie Nationale de Belgique will be frequently consulted.

Among the old authors who can be read for pleasure as well as for profit the present writer would include :-

Baker, H. The Microscope Made Easy. Second ed., I743. -Employment for the Microscope. I753.

Belon, P. Observations de plusieurs singularitez et choses mémorables trouvées en Grece, Asie, Judée, Egypte, Arabie, et autres pays estranges. I 553 .

_ Histoire de la nature des Oyseaux. $\quad$ I555.

Buffon, Comte de. Histoire Naturelle. Forty-four vols., of which thirty-six appeared during Buffon's lifetime. I7491804. Selected passages only.

Cuvier, G. Ossemens Fossiles. 1812. Fourth ed. in ten vols., besides two of plates, I834--36. Selected passages only.

Hooke, R. Micrographia. 1665.

Huber, F. Nouvelles observations sur les Abeilles. 1792. Second ed., two vols., I8r4. I8ro.

J. P. Recherches sur les mours des Fourmis indigènes.

Le Roy, G. Lettres sur les Animaux. 1781. Reprinted, 1862 .

Linnæus, C., and his Pupils. Amonitates Academica. Seven vols., I749-69.

Contain interesting discussions here and there among much that is now valueless.

- Lachesis Lapponica; or, A Tour in Lapland. Translated by Sir J. E. Sinith from the original diary. Two vols., I8I I.

Ray, J. Catalogus Plantarum circa Cantabrigiam nascentium. I660.

Réaumur, R. A. F. de. Histoire des Insectes. Six vols. 1734-42.

Redi, F. Experiments on the Generation of Insects. Translated from the Italian edition of 1688 by Mab Bigelow. Chicago, 1909. $6 \mathrm{r}$.

Roesel von Rosenhof, A. J. Insecten-belustigungen. I746Turner, W. On Birds. 1544. Translated by A. H. Evans, 1903. 


\section{INDEX}

AfFinity, 17, 5I

Agassiz, 122

Albrecht, 6r

Aldrovandi, 13

America, discovery of, 24, I 12

Aristotle, 2, 16, 17 n., 30, 39, 45, $47,63,73,102 n$.

Aselli, 2I

BACON, Francis, 39

Roger, 28

Bacteria, 137

Baer, Von, 66, 102, 104, 121,127

Bagehot, 135

Baker, 67,69

Barry, 106

Belon, 13

Bernard of Breydenbach, 23

Bestiaries, 6, 23

Bichât, I0.5

Bock, 9, 12, 37, 124

Bonnet, 45,60

Bonpland, 118

Bossuet, 66

Brown, $105 n$.

Brunfels, 9, I 2

Buffon, 40, 45, 63, 68, 71, 94 n., $95,120,130$

Busbecq, I13

Butler, 67

Caignard-Latour, 137

Caius, 19, 67

Camerarius, 48

Cesalpini, 12, 17 n., 34, 37, 80, 85

Chamisso, 100

Charlemagne, 25

Clodd, $65 n$.

Clusius, 111,113
Cole, 86

Compton, 116

Copernicus, 20

DARWIN, C., 46, 66, 75, 9I, 92, I 20, 121,124

E., 120

Davaine, 138

Descartes, 69

Dioscorides, 4

Dumas, 106

Duverney, 36

ENCYCLOP ÆEDIC Naturalists, 12

Erasistratus, 4

Evelyn, 111, 115, I16

Experiments of ancient Greeks, 3

FABRICIUS, 21

Fagon, 115

Flemings, 26

Fontana, $105 n$.

Forbes, 131

Fries, 17

Frisch, 37, 67

Fuchs, 9, 12

GAERTNER, 86

Galen, 4, 2 I

Galileo, 28

Galton, $6_{3} n_{\text {. }}, \mathbf{1}_{35}$

Geer, De, 37, 68

Gerarde, 20

Gesner, $11,13,17 n_{\text {. }} 18,19,20$, I1 3

Goethe, 8o, 8r, 84, 85

Greenhouses, 114

Grew, 32, 47, 86 
Hales, 68, 77

Hamm, 34

Harvey, 21, 102

Hedwig, 87

Heide, 37

Helmont, Van, 77, 136

Herophilus, 4

Hofmeister, $83,85,108,109,122$

Hooke, 29, 34, 37, 105

Hothouses, I 44

Huber, 68, 77

Humboldt, 118

Hume, 72

Hutton, 66

INGENHOUSZ, 79

Jussieu, B. de, 5 I

A. L. de, $5^{I}$

KANT, I 20

King, 36

Kirby, 68

- and Spence, 55, I 33

LAMARCK, 46

Laplace, 120

Leeuwenhoek, 32, 40, 58, 60, 68, 86, 106, 137

Leibnitz, 45,64

Leroy, 68, 73

Lessing, 120

Lindsay, 86

Linnæus, 48, 49, 52, 64, 80, 82, $85,87,90,92,124,130$

Lister, Lord, 138

- M., 35, 43, 67

L'Obel, 12, 26, 124,130

Locke, 70

Lyell, 66, 67, 94, 12 I

Lyonet, 34, 58, 60, 6r, 67

Malphighi, 32, 36, 40, 45, 47, 127

Marco Polo, 23

Master, 36

Mattioli, II 3

Medicine and botany, 7

Méry, 37, 38, 67

Micheli, 87

Microscope, 28, 48

Middle Ages, 5, 6, 25

Millington, 47

Mohl, 106

Montagu, 68

Montesquieu, 63,120

Morgan, Lloyd, 74

Morison, 86

Moufet, 20

Needham, 40

Newton, 63

OLIVER and Scott, 83,85

Ortus Sanitatis, 16

Paley, I 33

Palissy, 34

Pallas, 46

Parkinson, 20

Pasteur, I 36

Pecquet, 22

Perrault, $36,37,67$

Peter Martyr Anglerius, 24

Physiologus, 6

Pliny, 5

Plumier, $115 n$.

Pope, 45

Poupart, $37,38,67$

Prévost, 106

Priestley, 77

Quackelbeen, II3

RATHKE, 104, 127

Ray, 17 n., 22, 35, 38, 41, 48, 68, 124

Réaumur, $37,40,54,60,64,68$, 70,87

Redi, 39

Rhineland, I I

Roesel von Rosenhof, 67, 69, Ioo

Rondelet, 13

Rudbeck, 22

SaRS, IOI

Saussure, De, 79 
Schleiden, 105

Scott and Oliver, 83,85

Schwann, 105, 106, 137

Seneca, 28, 113

Serres, Olivier de, 26

Smith, 35

Socrates, 133

Spallanzani, 40

Spence, 68

Spencer, 122

Sprengel, 89

Stenson, 34

Suminski, 108

Swammerdam, 29, 37, 38, 40, 70, $86,103,106,133$

Theophrastus, 2,47

Titius, $124 n$.

Tournefort, $3^{8}$
Tradescant, II 5

Trembley, 57

Turner, 18, 67

Tyson, $3^{6}$

VALLISNIERI, 40

Vesalius, 20, 21

Vico, 63

Voltaire, 35

WALLACE, I 20

Wallis, 22

White, 68

Wolff, $80,82,84,85,103$

Woodward, 34

Wotton, 18

YEAST, $\mathbf{I}_{3} 6$ 


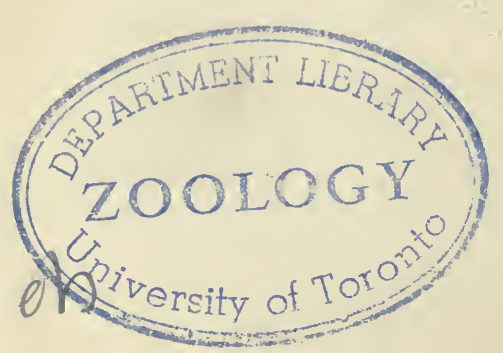





\section{Date Due}

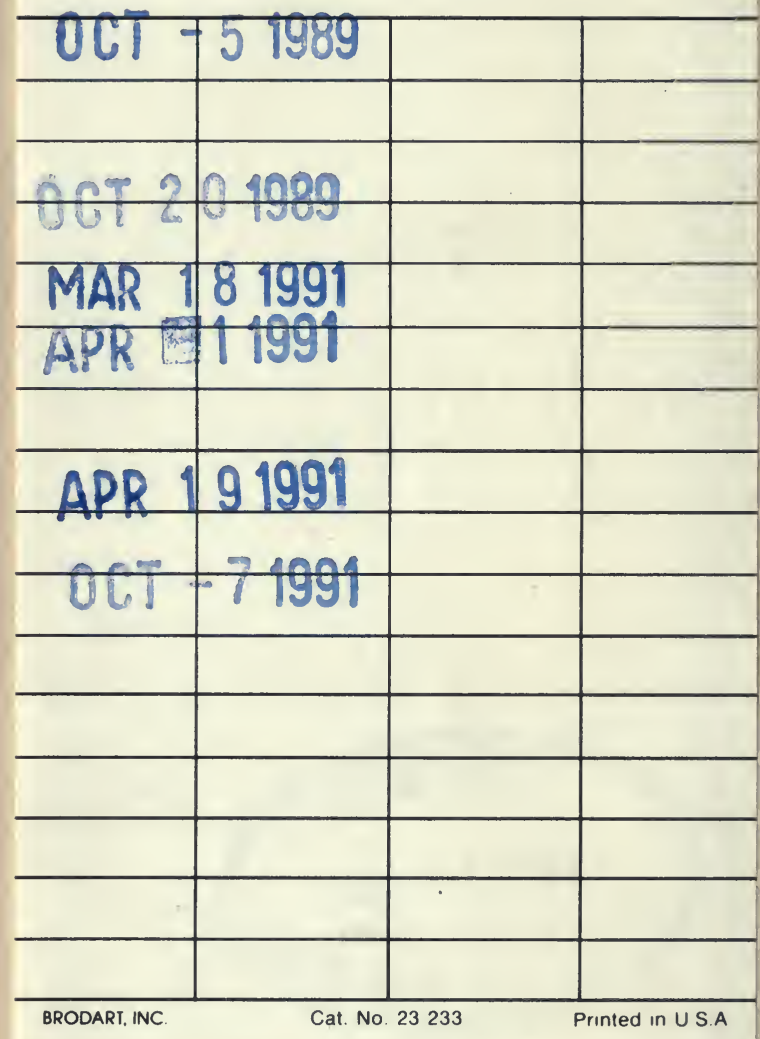


QH 305

M5

1911

c. 1

\section{1}

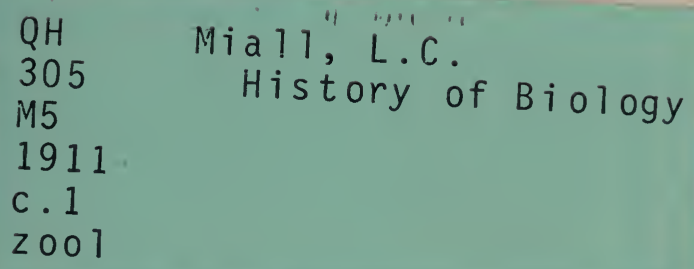

Mia 11, L.C.

Hisiory of Biology 
